\title{
POLÍTICA, LIBROS Y POLÉMICAS CULTURALES EN LA CORRESPONDENCIA EXTRAOFICIAL DE IGNACIO DE HEREDIA CON MANUEL DE RODA (1773-1781)
}

\author{
Jesús PRADELLS NADAL
}

Universidad de Alicante

\begin{abstract}
Resumen
El artículo analiza la correspondencia inédita que, desde 1773 a 1781, mantuvo desde París Ignacio de Heredia y Alamán, secretario y hombre de confianza del Conde de Aranda, con Manuel de Roda, Secretario de Gracia y Justicia, destacando los aspectos relacionados con las polémicas acerca de la imagen de España en la literatura europea, el proceso de Olavide, el impacto de acontecimientos como la derrota de las tropas españolas en Argel en 1775 y, especialmente, los encargos realizados por Roda para adquirir libros en Francia.
\end{abstract}

\begin{abstract}
The Article analyses the unpublished correspondence maintained from Paris (1771 to 1781) between Ignacio de Heredia and Alamán, secretary and confident of the Count of Aranda, and Manuel de Roda, secretary of Grace and Justice. This correspondence highlights the aspects of the controversial image of Spain, as represented in European Literature, the trial of Olavide, the impact of events such as the defeat of the Spanish troops in Algeria in 1775 and above all Roda's mission to acquire books in France.
\end{abstract}

En el mes de junio de 1773 el conde de Aranda cesaba en la Presidencia del Consejo de Castilla que había servido desde 1766. Sus actitudes críticas ante la política de Grimaldi y sus enfrentamientos con el fiscal Campomanes determinaron a Carlos III a enviarle al dorado ostracismo de la embajada de España en París ', y con él

1. GÓMEZ DEL CAMPILLO, M. El Conde de Aranda en su Embajada a Francia (1772-1787), Discurso leído en el acto de su recepción..., Madrid, 1945. OLAECHEA, R. y FERRER BENIMELI, J.A. El Conde de Aranda (Mito y realidad de un político aragonés), Zaragoza, 1978, 2 vols. FAYARD, J. Y OLAECHEA, R. «Notas sobre el enfrentamiento entre Aranda y Campomanes», Pedralbes, $n^{\circ} 3$ (1983), 
viajó quien había sido su fiel hombre de confianza desde que Aranda fue destinado a servir en la Capitanía General de Valencia, don Ignacio de Heredia y Alamán².

Don Ignacio de Heredia nació en Graus el 31 de agosto de 1728 en el seno de una una familia de la baja nobleza aragonesa, y algunos de sus enlaces familiares eran muy apreciables, pues, según escribió a Roda, era primo del conde de Villasenor, «a quien debi en su testamento hecho en Nápoles, que me dejara dueño de tomar todo lo que quisiera de los muebles de su casa» ${ }^{3}$. Primogénito de los ocho hijos de don Juan Francisco Heredia y Subiza y Doña Antonia Alamán Cavero, natural de Naval (Huesca), cursó las primeras letras en el Colegio de los jesuitas de su ciudad natal, e ingresó, en el curso 1744-1745, en la Universidad y Estudio General de Huesca. A los dieciséis años, con recomendación del Obispo de Barbastro, tío abuelo suyo por parte de madre, ingresó en el colegio de San Vicente. En 1752 recibió la tonsura eclesiástica, aunque el hecho de no haber cursado estudios de Teología hace a Olaechea disipar la hipótesis de una temprana vocación clerical, aunque se doctorara también en Derecho Canónico. En abril de 1757 se trasladó a Madrid, y entró de "minutante" en la Secretaría de Gracia y Justicia con el marqués de Campo Villar. Aranda le llevó consigo cuando fue nombrado Capitán General de Valencia y, a su regreso a la Corte, promovió a Heredia al cargo de Comisario de Guerra y Secretario del Consejo de Castilla, que sirvió hasta que Aranda consiguió que se le habilitara como oficial de la Primera Secretaría de Estado, requisito imprescindible para poder ejercer el empleo de secretario de la embajada en París ${ }^{4}$.

El 12 de agosto partió Aranda de incógnito desde Madrid hacia San Ildefonso para despedirse del rey y recibir de Grimaldi las instrucciones y credenciales. Dos días más tarde emprendían viaje hacia hacia la frontera francesa tomando la ruta de Segovia y, nada más pasar la raya de Francia, Heredia inició una correspondencia particular con su paisano y amigo Manuel de Roda ${ }^{5}$, de la que se conservan las escri-

pp. 5-59. OLAECHEA, R. «Información y acción política: El Conde de Aranda», Investigaciones históricas, 7, Valladolid (1988), pp. 83-130. Desde la perspectiva de Campomanes, LLOMBART, V. Campomanes, economista y político de Carlos III, Madrid, 1992, pp. 102-106.

2. La documentada y, como siempre, penetrante biografía de Ignacio de Heredia en OLAECHEA, R. «lgnacio de Heredia y su biblioteca», Revista de Historia Moderna, $1^{\circ} 4$, Alicante (1984), pp. 211-291. Un agudo y colorista ensayo de su perfil psicológico en pp. 221-225.

3. [Heredia - Roda], París, I de noviembre de 177[8].

4. «Me alegro -escribía Azara a Roda el 7 de julio de 1773- de que al conde lde Arandal le hayan dado el gusto de dejarle a su secretario Heredia, y que a éste lo hayan hecho oficial de la Secretaria, porque al fin es nuestro paisano, y mi amigo desde la niñez». El espíritu de D. José Nicolás de Azara descubierto en su correspondencia epistolar con Don Manuel de Roda, Madrid, 1846, I1, p. 429.

5. Don Manuel de Roda y Arrieta (1708-1782), calificado de manteista de «origen oscuro», nació en Zaragoza el domingo 5 de febrero de 1708 . Hijo de Juan Roda, natural de Maella, y Manuela Arrieta, natural de Zaragoza, fue bautizado en El Pilar. Cursó las primeras letras en su ciudad natal con los jesuitas, y estudió leyes en calidad de manteista. En contra del partido ensenadista, que representaba la coalición jesuitas-colegiales, Roda se adscribió al partido del duque de Alba, personaje antipático a Carlos III, del que Roda se consideraba «hechural». Un Ministro del equipo ensenadista, el marqués de Campo Villar, sobrevivió a la crisis de 1753 y logró permanecer al frente de Gracia y Justicia hasta su muerte en 1765. 
tas por el Secretario de la embajada hasta abril de 1781, poco más de un año antes de la muerte del Ministro de Gracia y Justicia, sobrevenida el 8 de agosto de 1782 .

Aunque lamentablemente no hemos podido contar con las escritas por Roda, las de Heredia tienen el valor singular que dimana de su carácter particular y confidencial, al margen de las exigencias formales de la correspondencia de oficio ". Tanto Aranda, como Heredia y Roda se sirvieron de diferentes canales de trasmisión, a menudo en función de la «calidad política» de las noticias y comentarios. Unas veces aprovecharon la oportunidad que brindaba el trasiego de los correos extraordinarios entre las cortes de Madrid y Versailles, en otras los correos ordinarios y, en las ocasiones más comprometidas, del tránsito de personas de confianza o del subterfugio, por lo demás muy habitual, de incluir en las cartas dirigidas a amigos comunes algunos pliegos en sobrescrito.

El variopinto contenido de la correspondencia de Heredia con Roda presenta tres hilos conductores que discurren en paralelo. La amistad personal de dos hombres que sintonizaban abiertamente debido a sus comunes raíces aragonesas, a su devoción por los libros y a un ideario político-religioso coincidente en sus principales lineas de fuerza, aunque posiblemente con un talante regalista más radical en el caso del Ministro de Gracia y Justicia.

Durante los primeros años, la correspondencia entre ambos personajes discurre con la naturalidad que dimanaba de la amistad todavía caliente por el contacto más cotidiano que ambos tuvieron en la Corte como consecuencia de los cargos que desempeñaron. Roda al frente de la Secretaría de Gracia y Justicia desde 1765, desde la que se manejaron con destreza muchos de los hilos que condujeron a la expulsión de los miembros de la Compañía de Jesús ${ }^{7}$. Heredia desde su empleo de Secretario del Consejo de Castilla, al que el conde de Aranda le elevó al ser llamado a Madrid para afrontar, primero la situación creada por los motines contra Esquilache, y luego como ejecutor de la logística de la «operación cesárea» que culminó con el destierro de los jesuitas.

Aunque el paso del tiempo no llegó a desmerecer la amistad existente entre ambos, la profundidad de las confidencias políticas de los primeros momentos, estrechamente relacionadas con las espectativas de Aranda de regresar pronto a Madrid, se fue difuminando, para brotar ocasionalmente ante acontecimientos de magnitud extraordinaria, porque tanto Roda como Heredia eran conscientes de los límites existentes entre la amistad y la política.

El primer puesto de relevancia que Roda ocupó en la Administración fue el de Consejero de Capa y Espada en el Consejo de Hacienda (1757), para desempeñar más tarde el empleo de Agente de Preces en Roma (1758-1765), aunque actuó también como Embajador interino durante un largo período (17601765) antes de ser llamado por Carlos III para tomar las riendas de la Secretaría de Gracia y Justicia, de la que fue titular hasta su muerte en 1782. PINEDO, Isidoro.. Manuel de Roda. Su pensamiento regalista. Zaragoza, 1983.

6. A.G.S. Gracia y Justicia, leg. 778 .

7. PINEDO, Isidoro. Manuel de Roda. Su pensamiento regalista. Zaragoza, 1983. 
Aranda y Roda mantuvieron también una correspondencia muy confidencial, repleta de comentarios a la baturra. Para el Conde era una cuestión fundamental poder contar con un hombre tan próximo a Carlos III como lo era Roda para pulsar el ambiente que se respiraba en la Corte hacia su obra y su persona y, en definitiva, con alguien que le guardase las espaldas, en expresión del propio Embajadors. Por otra parte, Aranda mantuvo su apoyo a algunos personajes que se habían situado en su órbita durante su etapa al frente del Consejo de Castilla, trasmitiendo a Roda su voluntad de proteger sus carreras u opinando acerca de sus cualidades?.

La correspondencia de Heredia con Roda, mucho más amplia y diversa que la del Conde, puede contemplarse en ocasiones como el desarrollo de las cartas casi impresionistas de Aranda y, en cierto modo, constituye también un termómetro para medir la temperatura de las relaciones entre el embajador y Roda.

El relativo enfriamiento de las confidencias políticas entre Roda y Aranda se acentuó considerablemente desde la salida de Grimaldi y la promoción de Moñino a la Primera Secretaría de Estado, y aunque no impidió que la correspondencia entre

8. «S.E. se alegró mucho de ver la carta de V.E. que le leí, porque estaba en los mismos recelos que yo sobre el silencio de V.E». Heredia-Roda, París, 3 de diciembre 1773. «Digame V.E. -escribía Aranda- si en su despacho se miran las cosas de mi tiempo con desagrado, y si después que yo partí ha notado V.E. explicaciones en mal o en bien (...) Quanto digo aqui se me aprueba, y no han faltado asuntos fuera del común. Por lo que toca a los de por ahí ni una palabra». Aranda-Roda, París, 20 de enero 1774 [Autógrafa]; «Si V.E. no me quiere escribir, lo dispenso; yo estoi bien seguro de su afecto, y más quiero que me guarde las espaldas, que no el que me haga cumplidos». Aranda-Roda, París 22 de marzo de 1777 [Autógrafa].

9. El 28 de marzo de 1774 escribía Aranda: «Debo manifestarme reconocido a V.E. por la colocación de Bernad; por fin está en carrera, que puede seguir, y hará con el tiempo un excelente Alcalde de Corte»; el 20 de abril de 1774: «Bien me parece la elección de Mora y Jarava para fiscal de la Sala; según su modo de pensar en algunos asuntos no sé si sería igualmente bueno para el Consejo. Celebraré que Espinosa llene el hueco a que ha ascendido»; el 11 de mayo del 74: «Escriví a Bernad que por qué no se iba de Zaragoza, y si podía conocer que el Decano romano no quería de él, sino en su lugar alguna hechura suya. He sabido que ha tenido cuatro meses de prórroga, con todo le repito que no los complete; y a fe mía que me hace mui mala obra que se vaya para mis cosas»; el 30 de septiembre de ese mismo año: «No puedo escusarme de escribir a V.E. por el Relator Canet para plaza de Alcalde de Corte; si proporcionándolo la Cámara, tuviesse VE. Arbitrio, espero que se lo aplique (...) Sebastián el de Zaragoza tiene dado a V.E. un memorial, no tengo presente sobre qué solicitud. Es buen mozo de talento, aunque baldado de pies, y por ambas razones es acrehedor a la protección de V.E»; el 20 de noviembre: «Oigo que nuestra Ilustrísima Cámara va limpiando los Colegios maiores de quanto hai bueno y malo, proponiéndolos. Si VE. No procura introducir en ella algunos que contengan, ha de tener mucho trabajo en remediarlo por sí solo al dar cuenta a S.M. El más a propósito sería Acedo Rico; es hombre integro, y de tesón, que alli dentro causaría sujeción, y lo considero hombre de bien para ser reconoci$d o »$; el 25 de febrero de 1775: «Me intereso mui de veras por el abogado Cantero, uno de los mejores de Madrid; creo que huviera hecho un gran teniente de Corregidor, y está cortado para qualquiera fiscalía. Pido a V.E lo proteja y atienda, y si se le presenta, lo honrre» (...) Acedo está mui reconocido a VE. Y lo considero hombre de conservar su gratitud a sus bienechores"; el 22 de julio de 1776: «Sea motivo de manifestar a V.E mi reconocimiento, el favor que ha dispensado a Don Thomás Bernad para la plaza de Alcalde. Yo espero que su honrradez, y exercicio que ha tenido contribuyan a su desempeño»... 
ambos personajes se mantuviese viva, se hace también patente en el caso de Heredia cierta tibieza, pues, desde esas fechas fueron las noticias referidas a la vida parisiense, a la guerra de emanciación de las colonias norteamericanas -caracterizadas éstas por un marcado tono gacetillero- y las cuestiones relacionadas con los libros, las que pasaron a constituir el principal telón de fondo. Por su parte, Heredia siempre se esmeró en mantener las buenas relaciones con el Ministro, sin desaprovechar las ocasiones para colocar el mochuelo de un considerable número de recomendaciones para amigos y familiares, y especialmente para uno de sus primos, pretendiente ante la Cámara de Castilla y, sobre todo, dando casi siempre cumplida satisfacción a los encargos que Roda le hacía para alimentar a «su dama», conforme Roda gustaba de denominar a su biblioteca.

Desde la perspectiva cultural, la correspondencia permite reconstruir con algún detalle la imagen que Heredia, que nunca antes había salido de España, se forjó de la Francia real. Don Ignacio tuvo la oportunidad de contrastar personalmente los arquetipos y las distorsiones que habían ido construyéndose sobre el país vecino, tanto desde los ambientes ilustrados, como desde las posiciones de los más conservadores y tradicionalistas, para quienes los aires philosophicos de allende los Pirineos no podían traer nada provechoso ni para la religión, ni para el Estado ni para las buenas costumbres. Su correspondencia con Roda posibilita recomponer no sólo sus andanzas de bibliófilo en París, que le permitieron formar una tan nutrida como variada colección de libros ${ }^{10}$, sino también las opiniones y juicios que le merecieron las polémicas político-culturales del momento, y de manera muy especial, las relacionadas con la imagen de España transmitida por algunos «plumíferos» galos e ingleses. Cuestión esta que se convertiría en un asunto tan sustancial como los intentos realizados desde España para reivindicar la dignidad nacional y el papel de las aportaciones españolas a la cultura europea. Clarke, Reynal, Laporte, De Pauw, Robertson y otros autores no tardaron en recibir las andanadas críticas de Heredia, aunque reconociendo también sus valores, y siempre en marco de referencia de la política española en el contexto europeo en la década de 1770, por entonces sacudida por acontecimientos de tan amplia resonancia en Europa como el proceso contra Olavide, el desastre de Argel, la cuestión de Sacramento y la guerra de emancipación norteamericana.

\section{ARANDA Y HEREDIA DE CAMINO A PARÍS}

La primera de las cartas que Heredia dirigió a su paisano Roda la escribió desde Bayona, ciudad a la que la comitiva del conde de Aranda llegó la noche del 26 de agosto «sin otro tropiezo en el viage que el de havérsenos roto un exe de un coche a la salida de Tolosa, lo que por entonces nos dio un mal rato en el camino, y al día si-

10. Respecto a la biblioteca formada por Heredia en París escribía Olaechea que, en su opinión, se trataba «menos de la biblioteca de un verdadero "ilustrado" del XVIII, que de la "librería" de un honnête homme, cuya vida profesional -y social- discurría por los cauces propios de un diplomático español del Antiguo Régimen». «Ignacio de Heredia y su biblioteca», pp. 261-280. 
guiente nos retardó la jornada a esta ciudad. En todas partes han hecho mil demostraciones de estimación y amor a S.E., pues, aún en los pueblos en que no hacíamos alto, se llenaban de gente las calles para verlo. En esta ciudad se han excedido todos en cortejarlo, lo que nos ha tenido tan ocupados que ninguno tubimos ayer tiempo para escribir una carta por el correo. Sobre todos se ha excedido el Teniente General Conde del Hospital, Comandante de esta provincia, quien le ha hecho todos los honores de Mariscal de Francia, entregándole el mando en la parada y en el exercicio que hizo hacer a un Regimiento [de Vivarais], que lo exequtó con un aire, agilidad y variedad de eboluciones que nos sorprendió. Aunque no lo sabemos, tenemos por cierto que para ese tratamiento havrá tenido orden de la Corte, y que esta igualdad de honores será en consecuencia del pacto de familia.

Oy comemos en casa del Barón de Armendariz a la mano de Castelfranc, y desde alli tomamos el coche para continuar nuestro viage.

S.E. ha engordado mucho en el camino gastando en todo él bellísimo humor, y no acordándose, salvo para reir, de las cosas pasadas. Me ha encargado decir a V.E. sus expresiones, y yo quedo a su arbitrio, su más afecto y reconocido serbidor»".

Desde la ciudad del Adour prosiguieron ruta hacia París por Burdeos: «Después de haver logrado un tiempo bellísimo en el camino, de havernos continuado en cortejar en Burdeos ${ }^{12}$, de havérsenos roto dos veces más el mismo exe de antaño, y de habernos robado con la mayor desbergüenza en toda la carrera de Francia, llegamos en fin a esta Corte el día 8 del corriente, a las ocho de la mañana, con toda felicidad en la salud, y con nuevas creces en la de S.E., quien ha podido lograr lo que deseaba de mantenerse incógnito por tres o quatro días a causa de hallarse el Rey fuera de Versalles, con lo que ha tenido lugar de equiparse de coches y componer la casa, y pasará a presentarse en la Corte el domingo por la mañana.

Hasta aquí no lo han visitado sino dos o tres conocidos antiguos, y ayer tarde los Duques de Richelieu, y el de Equillon [d'Aiguillon]; y éste creo que nos ha de hacer muchas fiestas, pues en el camino tubo S.E. noticia cierta de que se havía explicado lleno de miedo de que le havía dicho que S.E. quería visitar al paso de Amboise al Duque de Choiseul» ${ }^{13}$.

La primera visita oficial estuvo dedicada al Secretario del Despacho de Negocios Extranjeros, duque d'Aiguillon, y Luis XV ofreció la recepción solemne al nuevo Embajador el día $12^{14}$.

11. [Ignacio de Heredia - Manuel de Roda], Bayona, 28 de agosto de [17]73.

12. Poco después de que se detuvieran en una posada llegaron también «el Conde de Barrí, marido de la Madana, y el Marqués de Barri, su hermano, que iba a casarse con la hija única del Conde de Fresnel, Comandante de las armas de aquella probincia en ausencia del Duque de Richelieu. Nada de esto sabia S.E. quando aceptó en aquella misma noche el combite que le hizo el Comandante para comer en su casa, con lo que logramos la honra de que nos acompañaran en la mesa estos dos caballeros». Ibíd, 10-9-1773.

13. [Heredia - Roda], París, 10 de se[p]tiembre de 1773.

14. OLAECHEA y FERRER, El conde de Aranda, I, p. 48. «Ignacio de Heredia y su biblioteca», p. 234. Aranda - Roda, París, 14 de septiembre de 1774 [Autógrafa]. 
Por su parte, Heredia, en el tiempo que le dejaban la instalación y el ajetreo de los primeros días de estancia en la entonces capital de Europa, recuperaba para sus amigos las anécdotas e incidentes del viaje. Con motivo de enviar un correo extraordinario a la corte española con la respuesta de María Teresa de Austria a la carta en la que Carlos III le comunicaba la extinción de la Compañía de Jesús, Heredia aprovechaba para contarle a Roda algunos de los incidentes pintorescos sobrevenidos en la ruta hasta París. En uno de los recambios de posta, y aprovechando la oscuridad de la noche, les habían puesto tres caballos de menos en los tiros; mientras varios posaderos pugnaban acaloradamente para que el cortejo se detuviera en su establecimiento cuando llegara a Poitiers. En Chatelereau los edecanes de Aranda se vieron obligados a intervenir para librar al Conde de la turbamulta de vendedoras de cuchillos que le asediaron al salir de misa. Las primeras imágenes que Heredia trasmite de Francia se componían de tópicos como el de «la codicia tan extraordinaria de estas gentes, y el extremo con que los domina», pues, además de la picaresca de los posaderos y las solicitudes de toda clase de vendedores, le llamó poderosamente la atención el que «en las iglesias hacen pagar un sueldo del asiento, y que después de la elevación de la misa lo van cobrando una quadrilla de mugeres con un alboroto que me dejó escandalizado» ${ }^{15}$.

\section{LA VIDA COTIDIANA EN PARÍS}

Al llegar a París Aranda se instaló en el palacio que el marqués de Soyecurt tenía en la Rue de la Université, el mismo en el que había vivido su antecesor en el cargo, el conde de Fuentes. Pero la residencia no satisfizo ni las necesidades de espacio ni las que Aranda consideraba dignas para la alta representación de su Soberano, y la suya propia. Al respecto Heredia escribía a su paisano el primero de octubre: «S.E. continua sin nobedad, pero muy ocupado desde que llegó en equiparse y alojarse. Desde luego le disgustó la casa en donde paramos. Estubo algunos días indeciso entre hacer de nuevo algunas obras, o mudarse a otra. En fin se resolvió este último partido y ha tomado el hotel Mazarin, que oy es del heredero de Paris de Monmartel, alajado en un todo por su dueño, en 22 mil libras al año. Es magnifico y estaremos todos grandemente alojados, aunque no lo empezaremos a disfrutar hasta la buelta de Fonteneblo [sic] para donde partiremos el ocho del corriente» ${ }^{16}$.

Las reformas que se hubieron de acometer en el palacio de «la rue Neuve des Petits Champs», que Aranda ocupó hasta febrero de 1782, se demoraron más de lo previsto, pero el 7 de enero Heredia escribía exultante a Roda acerca de lo contentos

15. [Heredia - Roda], París, 14 de Selp]tiembre de 1773. Con la misma fecha Aranda escribía: «Ha llegado el brebe de extinción de los jesuitas; los obispos cosquillean; el Arzobispo de París demuestra no querer conformarse. Dicen que el Papa sin concilio no puede extinguir una orden, que mereció ser aprobada, y reconocida por un concilio. Pero concibo que todo calmará. (...) En Alemania algunos Principes, y auin elector eclesiástico con sólo el impreso del brebe, sin aguardar la comunicación, y remisión de Roma en forma, han procedido a Secularizar a los jesuitas de sus dominios».

16. [Heredia - Roda], París, 13 de octubre de 1773. 
que estaban todos en la nueva residencia, «... a donde nos trasladamos en 22 de diciembre, porque los alojamientos son grandes y cómodos, y magníficamente alajados. Yo tengo en el mío cuatro chimineas [sic], ocho espejos grandes, y hermossísimos bronces dorados a fuego en la chimineas y en las cerraduras de las puertas. Se conoce en toda la casa la riqueza de su dueño que fue uno de los fermieres más ricos que ha tenido la Francia en este siglo» ${ }^{1}$.

Aunque las obligaciones oficiales cobraron ritmo enseguida, Heredia procuró siempre sacar tiempo para disfrutar de su afición a los paseos y explorar las delicias parisienses, visitando solo, o en compañía del Conde, los teatros de la Ópera, de la Comedia y el de los Italianos, de manera que Aranda se permitía bromear con Roda a costa de su secretario escribiéndole, apenas trascurridas unas semanas de su llegada a París, que: «Don Iñigo se va poniendo petimetre, pero nunca olvidará que fue del Colegio de San Vicente, y le gustaba más el gorro blanco de hilo sudadillo, que un peluquín bien ensortijado» 18 .

El 3 de noviembre escribía Heredia: «Tiene V.E. razón en havernos creído ocupados y fatigados hasta aquí, pues en realidad con el viage de Fontainebleau, la boda del Conde de Artois, y la mudanza de casa, havemos andado atropellados, y lo peor es que aún no estamos con sosiego, por no haver podido mudarnos a la casa nueva, que hace un mes nos van llebando de semana en semana, y creo se verifique en ésta. Por lo demás todos estamos buenos, y nos prueba admirablemente este país. Yo he perdido ya el miedo que tenía a las nieblas, y ni me acuerdo del sol. No he podido habituarme aún a salir de casa por las mañanas, pero paseo grandemente por las tardes, saliendo al anochecer (que es la hora poco menos en que se acaba la comida) y andando hora y media o dos horas por las calles, en las que siempre encuentro muchas señoras llenas de misericordia que creyéndome traspasado de frío me combidan con su chiminea. Ha havido noche en que han pasado de veinte en sóla la calle de Saint-Honnoré, tan bien portadas que parecen unas Duquas [sic]. Sin duda que en tiempo de Pisón no havría llegado aún a tan alto punto esta virtud, pues no se la havemos oido elogiar como merece» ${ }^{19}$.

En el mismo sentido habían girado también las primeras impresiones costumbristas que había trasmitido a Roda apenas unos días antes: «V.E. se acordará de haver oido ponderar a Don Antonio Pisón el miedo y respeto que le causaba el entrar en el paseo del Paleroyal [sic] por la sebera censura que se hacía de todos los que pasaban por sus calles. Para que vea que tengo yo más valor sírbase V.E. de decirle

17. Heredia - Roda], París, 7 de enero de 1774.

18. Aranda - Roda, París, 2 de octubre de 1773 [Autógrafa].

19. [Heredia - Roda], París, 3 de diciembre de 1773. El 16 de diciembre de 1776 el conde de Kaunitz informaba a Viena de la desgracia del «lector» - [Vorleser]- de la Princesa de Asturias, que fue privado de su cargo y de su pensión. BERICHTE.... VI, p. 451 . Heredia se refería al mismo asunto: "Escriben de ahí la desgracia de Pisón, pero a nadie he oido el motivo. Yo recelo que sea efecto de algún chisme de que parece abunda en el día ese terreno, según lo escriben generalmente». [Heredia - Roda], París, 13 de enero de 1777. 
que, en el mismo día que llegué acá, viendo que los edecanes de S.E. no se atrebian a salir a la calle con su uniforme por el miedo que les habían infundido de no llebarlo ningún oficial francés, a fin de animarlos me ofrecí a ir en su compañía con un vestido de color de porcelana, con calzones azules, porque se me havian perdido los propios del vestido, sin espada, ni palo hasta que pudiera comprar uno en la feria de la plaza de Luis 15 que se tiene aora. Que haviéndolos podido reducir paseé mucha parte de la tarde en las Tullerias, y de allí me fuí a las funciones del nuevo Coliseo (obra hecha de madera, pero la más magnífica y hermosa que creo haya en la Europa) en donde estube de dia y de noche cercado de Patimetras, y de Filles entretenues. Que con el mismo equipage me presenté ayer en el Paleroyal [sic] a la hora del paseo de medio día, sin que nadie me haya mirado a la cara en ningún parage sino los soldados, que me hacían cortesía y se quadraban al pasar, reputándome por oficial protestante de la Orden militar del Mérito, a causa de ser su Divisa la misma que la de la Orden de Carlos terceros ${ }^{20}$.

Mucho más breves, pero igualmente expresivas, eran las noticias de Aranda, quien al describir a Roda sus primeras andanzas cortesanas sentenciaba: «Aqui muchas fiestas de bodas, gastos inmensos, gente volátil más que nuestros valencianos, y de todas clases viene a parar el dinero en comer, y bebern ${ }^{21}$.

Las primeras imágenes que Heredia trazó de su vida en París alternan, pues, entre una jocosa crítica moral y el sentimiento alegre del bienestar personal de que podía gozar en la mayor de las cosmópolis europeas del momento: «Hasta aquí -había escrito el 14 de septiembre de 1773-me he manejado en esta Corte con más soltura y libertad que ahí, pero desde oy empieza a angustiárseme el corazón porque a medio día nos presenta S.E. a Equillon [d'Aiguillon], en seguida al Rey y familia real, y inmediatamente tengo yo que visitar a todos los Embajadores y Ministros, que para quien no entiende la tercera parte de lo que hablan, ni se atrebe a explicar con quien no conoce, es un bravo negocio» 22 .

Un sentimiento de mayor libertad que, no sin cierta amargura, era compartido también por Aranda, liberado de las turbulencias de la vida política en Madrid, caractertizada en los últimos años de su Presidencia del Consejo de Castilla por un tenaz cruce de navajas con Grimaldi y Campomanes ${ }^{23}$, de manera que, el 23 de noviembre de 1773, le comentaba a Roda que: «... hasta ahora me va mui bien, y vivo en suma tranquilidad. Don Iñigo se aplica al francés y da paseatas aunque haya malas calles; y si llueve que impida, hace el picadero en su quarto» ${ }^{24}$.

20. [Heredia - Roda], París, 10 de se[p]tiembre de 1773.

21. Aranda - Roda, París, 23 de noviembre 1773. [Autógrafa].

22. [Heredia - Roda], París, 14 de se[p]tiembre de 1773.

23. «Yo-escribía Aranda-estoi mui contento de aver tomado mi partido, una vez que las cosas no iban con la confianza, que me parecía aver merecido (...) Esta va por extraordinario y dentro el pliego de mi muger, por cuya razón la creo segura (...) Crea V.E. que viviré siempre réconocido a su amistad, y corresponderé a ella firmemente». Aranda - Roda, París, 14 de septiembre de 1773 [Autógrafa].

24. Aranda - Roda, París, 23 de noviembre 1773. [Autógrafa]. 
Poco tiempo antes, en el mes de octubre, con motivo de felicitar a Moñino por su éxito en el negocio de la supresión de la Compañía de Jesús -y cuando éste se preparaba ya para regresar a Madrid poco antes de que sobreviniera la inopinada muerte del Pontífice- bromeaba Heredia acerca de su vida de «perdición» en París: «No quiero perder la ocasión de decir a Vm. que he recibido su carta con muchísimo gusto, por el buen humor que Vm. gasta en ella; la he leido al Sr. Embajador [Aranda], que la ha celebrado igualmente, y más ha dicho: que siente el pensar que Vm. ha de ponerse la Golilla.

Vm. piensa ofrecerme una gran cosa con poner a mi disposición toda la potestad espiritual de esa Corte romana; pues sepa Vm. que para nada de esto la he de menester. Acá, los Embajadores y adherentes no oyen Misa, y si asisten a la que el Rey oye, leen la Gazeta o están de conversación durante ella, y comen carne todo el año. Al que no le basta una Metresa acreditada, y reconocida por tal, tiene dos o tres, hasta donde llegan sus fuerzas de cuerpo y bolsillo. [¿]Puede dudar que, cuando esta práctica es constante y general, estará fundada en buenas razones? [i]Véngaseme Vm., a vista de esto, a hacer ostentación de sus facultades romanas! Reconozca Vm. nuestra superioridad, y entonces me resolveré a pedir a la Asamblea de Embajadores, que se tiene todos los domingos en París, que lo admitan a Vm. al goce y uso de estos privilegios, y que se le despache el rescripto en debida forma.

Amigo, si vuelvo a España como he venido acá, podrá Vm. besarme el pie con más fe que al Santo Padre, pero temo mucho que no pueda presentarle sino un zancarrón como el de Mahoma. Manténgase Vm. bueno, y mande cuanto guste a su amigo» ${ }^{25}$.

A principios de abril de 1774 esbozaba un cuadro del ambiente parisiense mucho más desinhibido en el aspecto moral y religioso que el de la corte española: «Estamos al fin de la quaresma y puedo decir a V.E. que acá no tiene tan mala cara como ahí. Acá de las seis partes de París las cinco comen carne por su propia authoridad con sólo el pretexto de que es cara la comida de pescado. Todos los bienestantes comen carne y pescado, y cenan. Los espectáculos duran hasta la víspera de ramos, y el miércoles, juebes y viernes de pasión va todo París a celebrarla al paseo de Longs Champs en donde las damas cortesanas hacen ostensión de lo que han hecho padecer a los bolsillos de sus amantes.

Yo fui ayer de pillo para poder observar mejor, y reparé una cosa que prueba bien el carácter de disolución que domina a este pueblo. La que más ha brillado en estas funciones ha sido mademoiselle D'Huttè mantenida por un milord inglés. Dicen que cada día ha sacado diferente tren. El de ayer era soberbio, de una rica berlina de seis caballos arrogantes y hermosamente enjaezados, y dos cocheros y tres lacayos todos galoneados de plata. En qualquiera otra parte la huvieran escupido en la cara, pero acá, lejos de eso, ví que era el ídolo del paseo; todos los petimetres se

25. Heredia a Moñino, Fontainebleau, 25 de octubre de 1773. Apud. OLAECHEA. «Ignacio de Heredia y su biblioteca...», pp. 235.236. 
apresuraban por llegar a besar la mano y darle mil enhorabuenas. Esto nada tiene de extraordinario, lo más notable era que el populacho, entre quien yo andaba, rebosaba de complacencia, se atropellaba por verla, y la llenaba de elogios y de bendiciones, llamándola "charmante", "l'aimable" y otros epitetos a este tenor» ${ }^{26}$.

El mismo sentimiento se desprende también de los reiterados testimonios del propio Heredia con motivo de enviar a Roda recuerdos del Nuncio de Roma en París, Monseñor Doria: «El Nuncio me pregunta siempre por V.E. y me encarga que le diga mil cosas de su parte. La primera vez que lo vea le he de leer el capítulo de la carta de V.E. en que hace tantos elogios de esta Corte, y espero reírme con los apodos que le ha de hechar a V.E.; porque es el mayor elogiador de nuestra Corte que se puede imaginar y públicamente dice que más quisiera estar de Nuncio 20 años en Madrid que uno en París. No puede sufrir el carácter de estas gentes, y le sobra la razón, y lo que sobre todo le tiene aburrido son las cortesías y los cumplimientos, que en realidad, no se puede concebir su estra[va]gancia sin verlos.

Yo tengo por cierto que a V.E. le sucedería acá lo mismo que al Nuncio; con que asi no tiene V.E. embidiarme otra cosa que la holgazanería que aquí tengo, y la libertad de hacer lo que se me antoja, sin miedo de los disgustos y sinsabores que ahí eran tan comunes, y acá no veo que pueda haverlos» ${ }^{27}$.

Aranda trasmitía también a su manera lo satisfecho que Heredia se encontraba en París: «Don Iñigo gordo como el cebón de San Antón, sobre que, sus aprehensiones, y restos de ideas colegiales tenemos nuestras peloteras, y somos tozudos a qual más. Nunca empuerca las bueltas de la camisa, hace exercicio sin fin, y si no peca, más es por miedo a mí, que a Dios, pues crehe firmemente, que si yo lo supiera, me hacía pregonero con todos sus pelos y señales» ${ }^{28}$.

El ritmo de la vida cotidiana de Heredia quedaba marcado por el calendario de Corte, con los indispensables desplazamientos a Versailles y los veraniegos a Marly y Compiegne, que le fastidiaban particularmente, mientras que las largas temporadas en París, a pesar del rumboso tren que Aranda imprimió a la embajada, dejaban suficientes resquicios para que Heredia se dedicara también a cultivar sus aficiones a los paseos y, sobre todo, a los libros.

«Al sonar la campana -escribía Olaechea- se sentaban cada día a la mesa de la embajada de quince a veinte personas fijas. Aun los dias en que Aranda iba a Versailles-más de cien al año-se servía comida, y Heredia era el encargado de hacer los honores, porque siempre solía haber invitados, y los viajeros españoles de París tenían acceso abierto. Además de esto estaban los banquetes y "convites formales". En tal caso, las comidas constaban de "treinta a cuarenta cubiertos", y la cenas "de

26. [Heredia - Roda], [París, sin fecha. Primeros meses de 1774, probablemente abril].

27. [Heredia - Roda], París, 7 de enero de 1774. «Monseñor Doria, a quien leí el capítulo de la carta de V.E., estimó mucho su memoria, y me encargó con grande encarecimiento lo ofreciera siempre a la disposición de V.E. Se porta acá con mucho juicio, y hace una vida irreprensible», [Heredia - Roda]. París, 18 de febrero de 1774.

28. Aranda - Roda, París, 26 de mayo 1774. [Autógrafa]. 
ochenta, cien y más personas, que se reunían a pasar la noche en la embajada”. En resumidas cuentas, que sólo la casa - cocina, alumbrado y calefacción, junto con las caballerizas-arrojaban un saldo de cincuenta a sesenta mil libras anuales» ${ }^{29}$.

Por la embajada de España desfiló la crema de la aristocacia y de la política francesa, y entre ellos personajes que, como el choiseulista abate Beliardi, habían desempeñado papeles importantes en las relaciones hispano-fracesas: «El Abate Beliardi bino con el Duque de Choiseul hará poco más de dos meses, pues desde que estábamos acá siempre havía permanecido en su compañia. Esta bueno y alegre. Biene a vernos algunas veces y hablamos largamente de las cosas de ahí. Tiene muy buena casa y mejor renta, pues la ha aumentado mucho con su vista, con lo que lo puede pasar acá como un Papa si el diablo no le abre la puerta para bolverlo a meter en intrigas y negocios» ${ }^{30}$.

París era casi una escala obligada para los diplomáticos españoles en tránsito de o a sus destinos, y por la embajada pululaban también un sin fin de transeúntes que eran tratados con arreglo a su porte, a la calidad de la recomendación o al capricho del señor Conde ${ }^{31}$. Pero de vez en cuando asomaban por París viejos amigos. El 4 de agosto de 1774 notificaba Heredia a Roda en postada que el Ministro de Parma, Agustín de Llano, había recalado en París en compañía de su mujer y del Agente de Preces en Roma, su paisano José Nicolás de Azara: «Don Joseph Agustín [de Llano], su muger y Azara están acá muy contentos, corriendo calles, teatros y quanto ay que ver acá, porque cuentan con partir a mitad del mes, pero yo creo que aún los encon-

29. «Luego venían los salarios de aquellos que Aranda, cual otro mesnadero, llamaba "mis gentes". El conde les pagaba según las diferentes graduaciones y categorias, "dotándolas-decía-excesivamente más de lo que haría en España, porque aqui en París deben presentarse con otra decencia" "

A todo lo dicho habia que juntar "el vestuario de algunas gentes de la casa, y la librea; la compra de caballos, el frecuente ir a Versailles, y el mantener una casa en dicho sitio real, con su alquiler, conserje y silleteros propios" (...)

Otro gasto nada despreciable era el de la secretaría, la asistencia decente de sus empleados y escribientes, "que entre todos hacian de cinco a seis personas"; los portes de las cartas y paquetes, y en fin, el aposentamiento de los correos y postillones de gabinete, portadores de los despachos oficiales, que se detenian en la embajada hasta emprender nuevo viaje, sin contar otros innumerables gastos personales, de representación, de teatros, de compras de objetos y de subscripciones a revistas, que no eran pocas. El 14 de junio de 1786 Floridablanca autorizaba a Aranda los gastos de subscripción de las siguientes publicaciones periódicas: Mercure de France, Journal de París, Journal Général de France, Gazette d'Amsterdam, Courier d'Europe, Journal Encyclopédique de Bouillon y Varietés politiques et litteraires. (...) El caso es que Aranda tuvo que vender tres de sus pueblos para mantener el decoro del real servicio». Concretamente las villa de Mislata y Benilloba en Valencia y la de Biota en Aragón)». OLAECHEA y FERRER, El conde de Aranda, I, pp. 51-52. Además, Aranda corrió en muchas ocasiones con gastos más que considerables. Así, por ejemplo, con motivo de mantener informado a Carlos III de la evolución de la enfermedad de Luis XV, y a falta de correos reales, despachó a sus propios criados. Aranda - Roda, 6 de mayo de 1774 [Autógrafa]. Vid nota 65.

30. [Heredia - Roda], París, 25 de febrero de 1775.

31. Una somera descripción de la embajada de España en la época de Aranda como «brillante centro en que son recibidos los viajeros españoles de la nobleza...». SARRAILH, La España ilustrada..., pp. 363 y ss. 
tremos a nuestra buelta» ${ }^{32}$. El 15 de agosto se volvía a referir desde Compiege a las andanzas de los ilustres personajes: «Llano y Azara creo que se aburren ya en París, y mucho más La Manchega ${ }^{33}$, según me ha dicho Magallón que bino hace dos días; con todo creo que los bolveremos a ver a causa de los baños que toma La Manchega. S.E. está bueno y yo me repito a las órdenes de V.E.» ${ }^{34}$. Por allí pasaron también el conde de Aguilar ${ }^{35}$, los duques del Infantado ${ }^{36}$, el marqués de la Torre ${ }^{37}$, el conde de Lacy de regreso de su breve misión en San Petersburgo ${ }^{38}$, los marqueses de Valdeíñigo de camino hacia Londres ${ }^{39}$, el marqués de Almódovar de camino hacia Londres ${ }^{40}$, y un largo etcétera.

Pero también pasaron por la embajada de España personajes con una notable proyección intelectual en la sociedad francesa y con los que Heredia trabó diversos grados de amistad. Heredia tuvo ocasión, por ejemplo, de hablar con el abate Clement, viejo conocido del Ministro de Gracia y Justicia ${ }^{41}$, con el abate Chaupi ${ }^{42}$, o con el «famoso» abogado Linguet, «author de la Theoría de las Leyes y de otras muchas obras, con que havia alborotado a los literatos por sus ideas que graduaban de estravagantes».

Linguet (1736-1794), que había estado en Portugal sirviendo de edecán al Príncipe de Baubeau antes de convertirse en un abogado de relieve en París, se vió envuelto en 1774 en un sonado escándalo a raíz de que el Colegio de Abogados le suspendiera por un año del ejercicio de la profesión. La Memoria publicada por Linguet

32. [Heredia - Roda], París, 4 de agosto de 1774.

33. Doña Isabel María Parreño y Arce, nacida en La Roda (Albacete) el 31-3-1751. José Agustín de Llano murió en 1794 e Isabel María contrajo segundas nupcias, en 1799, con D. Fernando Queipo de Llano.

34. [Heredia - Roda], Compiegne, 15 de agosto de 1774.

35. [Heredia - Roda], Sin fecha. [17 de agosto de 1775]. «Tenemos hospedado en casa al Conde de Aguilar y permanecerá acá hasta dos días antes de partir la novia a Turín».

36. [Heredia - Roda], París, 19 de julio de 1777.

37. [Heredia - Roda], París, 20 de se[p]tiembre de 1778.

38. [Heredia - Roda], París, 1 de noviembre de 177[8].

39. [Heredia - Roda], París, 23 de noviembre de 1778.

40. Almodóvar fue presentado a Luis XVI el 3 de julio de 1778. Gaceta de Madrid, 28 de julio de 1778.

41. [Heredia - Roda], Versailles, 6 de mayo de 1774. «El abate Clement está en París y hace 15 días que comi con él en una casa en donde nos hallamos combidados. Aunque lo havia visto una vez en Madrid no me acordaba de su fisonomía. Pero haviéndolo oído nombrar nos reconocimos, y hablamos largamente de V.E.».

42. «También me ha trahído para V.E. el Abate Xchaupi [sic] un exemplar de su obra de los Ciudadanos nobles de Barcelona y Perpiñan con la adjunta carta. Hace días que me la regaló a mí, y le propuse que se la embiara a V.E. Por lo que he visto me parece que está muy bien escrita, y lo singular es que el autor tiene noventa años, pero tan fuerte de cabeza y estómago que me ha dicho trabaja diez horas por día, y no he visto otro en la mesa de S.E. que coma más que él. Es Decano de la Sorbona y jansenista, y se ha hallado metido en todas las querellas de este siglo, sobre lo que me divierte muchos ratos». [Heredia - Roda], París, 21 de junio de 1777. 
en su defensa levantó tales ampollas que sus enemigos, encabezados por Gerbier ${ }^{43}$, consiguieron que el Parlamento de París dictase una providencia expulsándole definitivamente del Colegio. El asunto pasó al Consejo de Estado y suspendió cautelarmente la sentencia de los parlamentarios, «negocio de que se habla mucho acá por la fama de Linguet, y porque se recela que si éste triunfa no querrán los abogados concurrir al Parlamento a defender las causas.» ${ }^{44}$.

El 11 de marzo Heredia informaba a Roda que: «bino a verme Linguet, con quien he hecho ya amistad y he comido en su casa. Anteayer me dixo que su causa se havia debuelto por el Consejo al Parlamento con orden de que lo oyeran, y que en la semana que biene quedaria reabilitado por el mismo Parlamento que rebocaría su arresto, cuyo medio havia abrazado el Consejo por no sonrojar al Parlamento casándole su sentencia. También he sabido por él que, efectivamente, estuvo de edecán del Príncipe de Beaubeau en toda la campaña de Portugal, y que a su buelta estubo 15 días en Madrid, de donde traxo los principales poetas cómicos, los que le sirbieron para publicar el Theatro español que dedicó a la Academia de la Lengua Española, cuya obra vi yo en Madrid pero ignoraba su author ${ }^{45}$.

Heredia se mantuvo desde entonces al corriente de las actividades de su nuevo conocido y, en marzo de 1777, remitió a Roda «una carta de Linget al Conde de Vergennes, que es rarísima acá por las grandes precauciones que ha tomado el Govierno para impedir su curso. Por ella verá V.E. que en todas partes estan expuestos los Ministros a la censura de los insolentes; y éste es uno de los de primer orden que se conocen en Europa» ${ }^{40}$

Pero los escándalos de París resultaban fugaces con frecuencia. Heredia había prestado también especial atención a un pleito protagonizado por Pedro Agustín Caron de Beaumarchais, bien conocido en Madrid desde que hiciera una airada aparición para casar su hermana con «el pobre Clavijo», haciéndose luego «tan famoso con las Memorias que ha escrito, como Bilker en Inglaterra». Caron se había erigido ahora en protagonista de otro entuerto judicial a raíz de un pleito con el conde de la Banche por un asunto económico, la herencia de Duverney, en el que se mezclaron acusaciones de soborno y calumnias, cuyo resultado resumía Heredia en los términos siguientes: «Caron salió condenado a infamia en la sentencia; pero él ha quedado tan acreditado en esta Corte y en todo el reyno, que como está desacreditado el actual Parlamento que lo ha juzgado. Todas sus Memorias son una sátira cruel de sus contrarios, sazonada con tal gracia que ha encantado a los parisienses, los quales andaban como locos en busca de la última, por no poder bastar las prensas o satisfacer sus deseos. En los seis u ocho primeros días se bendieron diez mil, y huvo día en

43. GERBIER, Jean Baptiste (1725-1788). Vid. HAURÈAU, Barthèlemy: Catalogue chronologique des ouvres imprimés \& manuscrites de J.B. Gerbier, que possé de la Bibliothèque des avocats...., Paris, Durands, 1863.

44. [Heredia - Roda], París, 18 de febrero de 1774

45. [Heredia - Roda], París, 11 de marzo de 1774.

46. [Heredia - Roda], París, 22 de marzo de 1777. 
que se pagaron a seis pesetas. El pobre Clabijo hace uno de los papeles principales de la última memoria, pero puede consolarse con que ha hecho famosa su obra del Pensador, de modo que si la tuviera acá impresa en francés se haría rico con ella» ${ }^{47}$. Pero en los primeros días de abril resultaba que de «Caron ya no se habla palabra, ni tampoco de su contrario Goerman, a quien juzgó el Parlamento, sobre la acusación que intentó contra él Caron de haver usado de un nombre fingido quando fue padrino de un niño en el bautismo, y lo condene o "étre blamé", y a pribación de oficio»" ${ }^{48}$.

Sin embargo, el clima de mayor libertad de expresión, que entendía Heredia podía dar lugar a toda clase de abusos, no dejaba de repugnar la conciencia del morigerado don Ignacio: «Desde principio del año [1775] estamos inundados de Memorias que apenas nos dan tiempo para leerlas. Bomarché [sic], Linguet y Gervier [sic] nos divirtieron el mes pasado. Aora hacen la costa Richelieu, y el conde de Guines, Embaxador de esta Corte en la de Londres, el qual lleba ya publicadas seis, y se puede decir que no ha entrado aún en materia porque tiene intaco a su principal enemigo, Fort, que acaba de publicar una, y le ofrece otra sobre la marcha. Es un escándalo y un abuso enorme el que se hace de esta libertad de escribir y publicar las memorias, pues cada uno se forja los hechos a su fantasía, y regularmente habla con más altanería el que más miente; y sin tropezar en barras sacan todos los trapos a la colada y se tratan como labanderas. Este desorden, y otras observaciones que he hecho sobre el modo de proceder en estos tribunales, me hacen conocer que les excedemos de mucho en la policía de este ramo, y infinitamente en la integridad de administrar la justicia» ${ }^{49}$.

La imagen de la Francia del racionalismo y de la Ilustración se convertiría mucho más tarde en un mito, en un referente que, en su versión hispana, sería forjado en parte como contrapunto a la sociedad española más inmovilista, y utilizado por los intelectuales críticos en clave política. Para Heredia, «católico "ilustrado", en la acepción "crítica" del vocablo», y regalista «temperado»", muchos de los aspectos de la vida francesa aparecían discordantes con los estereotipos de les Lumières. El asombro que manifestó con ocasión de su paso por Burdeos al considerar mercantilizado el culto religioso, la autoridad real en entredicho, la venalidad de la justicia parlamentaria, las extravagancias de la Corte y de las «charmants» de turno, la frivolidad, la superstición y el charlatanerismo que campaba en los salones galantes, donde se ofrecían espectáculos de falsas crucifixiones y milagrerías, apenas eran nada comparado con la conservación de la tradición taumatúrgica del rey de Francia: «[i]Qué le parece a V.E. -le escribía a Roda- de los 2.400 lamparonistas que se presentaron en Reims a ser tocados por el Rey? Pues sepa V.E. que esta ceremonia se repite todos

47. [Heredia - Roda], París, 11 de marzo de 1774.

48. [Heredia - Roda], [París, sin fecha. Primeros meses de 1774, probablemente abril].

49. [Heredia - Roda], París, 25 de febrero de 1775. El episodio relativo al duque de Richelieu en GÓMEZ DEL CAMPILLO, Op. Cit, pp. 80-81.

50. OLAECHEA. «Ignacio de Heredia y su biblioteca», p. 231. 
los años quando cumple el Rey con la Iglesia, y que se suspendió en tiempo de Luis 15 porque el tal señor no se hallaba en estado de cumplir con la Iglesia hacía muchos años. Bien hecho está lo que ahí se hizo, aunque se ve que no fueron muy verdaderas las razones que de acá se expusieron; y me parece que combendría que no se haya puesto en la gaceta de ahí el número de los tocados, porque no buelvan las gentes a su antigua crehencia» ${ }^{51}$.

\section{LA CORTE Y LA POLÍTICA FRANCESAS}

La Francia a la que llegaron Aranda y Heredia era la de los postreros meses de vida de Luis XV. El 12 de septiembre Aranda había tenido la función de su presentación solemne en la Corte, y en carta autógrafa a Roda esbozaba con su campechanía habitual un particular balance de la situación: «Según el decir de las gentes prudentes, y lo que yo voi observando, esta monarquía va caminando a su precipicio. Parece que hai un desgovierno sin igual. La administración de justicia sino es venal, oigo que sea arbitraria, y el atraso escandaloso. Los pueblos mui gravados; el real erario exhausto. Los gastos de la Corte sin límite; y está atemorizada de qualquiera otra que le hable con tesón» ${ }^{52}$.

La enfermedad del bien aimé se manifestó en toda su gravedad el 27 de abril de 1774, pues la viruela se cebó en el cada vez más impopular soberano ${ }^{53}$. Aranda y Heredia se trasladaron a Versailles el día primero de mayo al tener noticia del agravamiento de la «mala[l]tie du Roy», y el día 6 escribía don Ignacio a Roda informándole de las últimas novedades de la «enfermedad del Rey, que se halla en el estado de la supuración de las viruelas, cuya operación va bastante lenta, lo que da cuidado, aunque no se nota simptoma que no sea regular. En los primeros dias tiraron a desfigurarle al Rey la especie del mal dándole a entender que era erisipela con granos, porque sólo le havian salido las viruelas en la cabeza y plantas de los pies; pero como después se le llenó todo el cuerpo fue entrando en recelos y ya conoció en fin lo que era, lo que fue fatal para madamme du Barrí, pues la embió a llamar anteayer, y le dixo que era preciso se fuera porque no quería le sucediera lo que le havía acaecido en la otra enfermedad que tubo en Metz, en que creo huvo bastante escándalo en el modo con que salió la matresa que entonces tenía. De resulta de esta explicación se fue por la tarde a Ruel, casa de campo del Duque de Aiguillon, distante una legua y media de este sitio, a donde la llebó en su coche la muger de éste.

Esta nación ha olbidado enteramente el nombre de "bien aimé" que dió a su Soberano, pues los que no desean su muerte, miran con indiferencia el estado en que

51. [Heredia - Roda], París, 30 de junio de 1775.

52. Aranda - Roda, París, 14 de septiembre de 1773 [Autógrafa]. Los aspectos relativos a los despachos oficiales de Aranda a Grimaldi fueron abordados con detalle por DANVILA en su Reinado de Carlos III, IV, y posteriormente por GÓMEZ DEL CAMPILLO en la obra anteriormente citada, por lo que nos limitaremos aquí sólo a la correspondencia de Aranda y Heredia con Roda.

53. Gaceta de Madrid, 17 de mayo de 1774, Versailles 1 de mayo. 
se halla, y sólo sentirán su pérdida aquellos pocos que en el día gozan de fabor. A nosotros nos importa mucho su vida, porque si llega a faltar o quedará ésto en una especie de anarchía por la inexperiencia del Delfin, o gobernará a esta Corte la de Viena por medio de la Delfina que tiene ascendiente sobre su marido, y es de genio vivo e intrigantes ${ }^{54}$.

Heredia pudo mantener puntualmente informado a Roda de los asuntos relacionados con el desarrollo de la enfermendad del rey aprovechando los frecuentes extraordinarios que Aranda envió a la Corte de Madrid, de manera que, el 9 de mayo, escribía: «... aunque estoy con la cabeza como un cántaro por lo mucho que he tenido que trabajar a causa de estar sólo y haverse juntado tantas cosas de una vez, aprobecho un instante para decir a V.E. que desde ayer a las cinco de la mañana se puso el Rey en estado de no dejar esperanza de su vida, y que es regular que quando salga esta noche el correo, digamos que ya ha muerto.

Dios ha usado de misericordia con este Señor, pues en la noche del 6 al siete en que se hallaba menos agrabado que en los días antecedentes, mandó llamar de propio movimiento al abate Maudoux. Se confesó a su satisfacción, y a las siete de la mañana recibió el viático; y a presencia de su divina Magestad dixo al Cardenal de La Roche-Aimon, Grand Aumorier, que expresara lo que le tenía comunicado. El Cardenal le respondió, $[i]$ lo manda V.M.?, y haviéndole dicho que sí, dixo el Cardenal al público, que por no poder hablar el Rey a causa de las llagas que tenía en la boca, lo hacía en su nombre. Que S.M., a exemplo del rey David, se arrepentía de la vida pasada y del escándalo que havía dado a sus vasallos a quienes pedía lo perdonasen y les aseguraba, que si Dios le dilataba los días de su vida, los emplearía en su serbicio, en sostener la religión, y en el buen govierno y la felicidad de sus vasallos.

Esto está hecho una confusión. Se asegura que luego que muera marcharán los Príncipes con sus mugeres a Marli, y las tres hijas que han asistido al Rey a Trianon, y que, como es regular, no comunicarán al Delfín las personas que han entrado en el quarto del Rey durante la quarentena. Véame V.E. pribado el Delfín de todos sus Secretarios y Consejeros de Estado, en cuya caso está también S.E.; y el campo abierto a las asechanzas de los que le estan sirbiendo. En buena ocasión biene la pretensión con la Inglaterra sobre la isla que nos han tomado en América.

S.E. dice que por el criado que despacha es buena ocasión para escribir a V.E. pues se bolverá luego», y concluía en la posdata «Aún vive el Rey» ${ }^{55}$.

Apenas dos días más tarde, el 11 de mayo, Heredia le notificaba la muerte del Cristianísimo, y sus intuiciones acerca de Luis XVI: «Del nuevo Rey dicen que es muy económico, amigo de la justicia, y enemigo de fachendistas y aduladores. Si así es será muy del caso para esta monarchía. Lo que yo he concebido de las veces que lo he visto es que su génio es obscuro, y tenaz en lo que aprehenda, de modo que se me figura en sus ademanes y modo de hablar como un focín de la parroquia de San Pablo» ${ }^{56}$.

54. [Heredia - Roda], Versailles, 6 de mayo de 1774.

55. [Heredia - Roda], Versailles, 9 de mayo de 1774.

56. [Heredia - Roda], París, 11 de mayo de 1774. 
Por su parte, Aranda escribía escribía en esa misma fecha: «Va el correo con la muerte de este Soberano; príncipe amable por su buen corazón, pero desgraciado por su conducta; dejando un gozo casi universal de su pérdida, por lo gravados que estaban sus vasallos. Veremos lo que hace el sucesor; quien para marido no sirve; dicen de él que será justo, económico y firme en sus resoluciones. Como tenga estas cualidades, estará libre de metresas ya que para ésto le ayuda la primera (...) Como he estado en Versailles desde el primer día de la enfermedad del rey, estoi maduro de la vida que allí se ha hecho. No se pueda dar gentes más volátiles, y noveleras» ${ }^{57}$.

Mientras tanto ya se habían barajado en la cabeza de Aranda algunos asuntos diplomáticos de trascendencia, aunque con escasas posibilidades de llegar a buen puerto. El 26 de mayo de 1774 Aranda aventuraba sus impresiones acerca de la nueva etapa de gobierno que se abría en Francia, y acerca de las posibilidades que pudieran producirse de cara a una hipotética sucesión de la Corona francesa, puesto que, el hasta entonces Delfín había dado muestras inciertas acerca de su capacidad para proporcionar nuevos herederos al trono, y la viruela, que había acabado con la vida de Luis XV, podía llegar a comprometer el futuro de la dinastía ${ }^{58}$. Respecto al nuevo monarca Aranda aventuraba que: «Si no engaña la pinta, mudará mucho el modo de vivir, y govierno de esta monarquía, porque el nuevo soberano, aunque sin la menor instrucción de sus negocios, tiene bastante luz, y bondad para verlos claros; no tiene distracción que lo separe de tomar gusto a tratarlos, y el espejo del reino antecedente lo comprende bastante.

Nosotros estamos en el caso de pensar seriamente, y con mucha anticipación a la sucesión de esta corona, sobre lo que escrivo en este despacho con bastante conocimiento de lo que puede ocurrir. Los chicos que hagan estos señores, si ellas no la pegan por otro lado, creo que V.E. y yo nos podiamos obligar a mantenerlos. Su salud no es la más firme, y les aguarda el azote de las viruelas.

Puede ser, que el amo se explique con V.E. y el Reverendísimo, y V.E. podrá comprender como piensa, y qué le parece mi proposición.

Debe ser destino mío, el que me toquen en todas colocaciones bocados duros. Quantas vezes pudiera yo decir "Hos ego versiculos feci, tulit alter honores". La lástima es, que quando el amo lo conozca, será tarde, o nunca; porque yo no me he de hacer mérito engañándole, que es arte bien fácill ${ }^{59}$.

Por su parte Heredia pechaba con la misión de completar las noticias acerca de los primeros oficios del «parroquiano de San Pablo» que, por el momento, iba «pintando bien, y todos los pasos que hasta aqui ha dado son de no admitir en sus negocios a la Parroquiana [María Antonieta], no obstante que ella ha procurado insi-

57. Aranda - Roda, París, 11 de mayo 1774. [Autógrafa].

58. El 14 de septiembre de 1773 había escrito Aranda: «Del Delfín aún se duda que haya consumado el matrimonio; del Conde de Provenza se da por positivo, que aín no. Queda por ver el $3^{\circ}$ que es el Conde de Artois, que según la pinta no fallará, pues es más vivo y robusto, y tiene bella persona; oigo que él mismo haya dicho a sus hermanos, que él desempeñará a la familia».

59. Aranda - Roda, París, 26 de mayo 1774. [Autógrafa]. 
nuarse. Observe V.E. bien después del arribo de este correo a los dos amigos del quiero viveza, que yo me los figuro muy embarazados para resolberse, y no cierto sobre la isla de Crabe, cuyo asunto no parece que presenta mal semblante en Londres» ${ }^{69}$.

El negocio de preparar una hipotética sucesión al trono francés había ocupado la atención de Aranda desde su llegada a Francia, hasta el punto de haberse llegado aconsiderar un posible matrimonio entre Luis XV y la Infanta española María Josefa. Desestimado éste, hilvanó la idea de «casar al Infante Don Gabriel con una hermana del Rey [Isabel Felipa], como un medio muy eficaz para disponer en su caso la succesión de esta monarquía a esa rama. Su exequción en lo principal y en sus incidentes pedía mucha atención y abría una larga carrera llena de trabajo y vigilancia; tanto basta para decir que se ha desgraciado» ${ }^{61}$.

La muerte de Luis $\mathrm{XV}$, que llevó consigo el inmediato alejamiento de la Du Barry ${ }^{62}$ de la Corte y un fortalecimiento de los dévots, con Maurepas a la cabeza, abría una una fase de espectativas políticas y de cambios en el Gobierno con el ascenso del duque de Berry al trono de Francia. Lo que generalmente se daba por supuesto es que el Triunvirato Maupeou, D'Aiguillon y Terray tenía sus días contados, y el 6 de junio de 1774 Heredia informaba a Roda que: «Acá han empezado ya las nobedades que se esperaban en el ministerio, pues el Duque de Aiguillon [sic] hizo dexación de sus empleos de Secretario de Estado y Guerra el viernes pasado. Unos dicen que por insinuación que le hizo hacer el Rey por Maurepas, su pariente; y otros que de propio movimiento, haviendo expuesto al Rey, que no pudiendo prometerse la confianza de S.M. por las siniestras impresiones que le influirían contra él, nacidas de las críticas circunstancias del reinado pasado, no podía serle útil en unos empleos que sólo podrían desempeñarse gozando de la confianza del soberano. Yo inclino a esto segundo, porque fue lo primero que se dijo, y lo hallo conforme al carácter desinteresado del Duque, que aún en la pensión que le ha señalado el Rey, de 40 mil libras, ha tenido la generosidad, según aseguran, de representarle que podía escusarse de este gasto al erario en las estrecheces en que se halla, por tener él lo bastante para mantenerse con decencia. Yo creo que nos debe ser sensible este paso porque estaba bien con nuestras cosas, y me persuado a que libre de las intrigas del reinado pasado, y con la confianza del Rey, huviera hecho un gran Ministro.

En Estado se asegura que le sucederá Berge[n]nes, Embaxador que está en Suecia; y en Guerra el Marqués de Muy, que a la caída de Choiseul no quiso serlo por no depender de madamme Barrí, pero hasta aquí no se han publicado aún estos nombramientos.

60. [Heredia - Roda], París, 26 de mayo de 1774.

61. [Heredia - Roda], Marly, 2 de julio de 1774. Sobre los proyectos matrimoniales vid. GÓMEZ DEL CAMPILLO, Op. Cit., pp. 23-31

62. «Supongo que ya sabe V.E. que a madamme Barri la destinaron luego después de la muerte del Rey al combento de Pont aux Damens, en donde se la dixo se le asistiría de cuenta del Rey» [Heredia - RodaJ, París, 26 de mayo de 1774. 
El Rey va acreditándose con su nación con los edictos que ha mandado publicar, en que persona el derecho que llaman del "Joyeux avenement à la courone", que importaría como 20 millones de libras; la refundición de la moneda que también sería costosa a los vasallos; y la seguridad que ha dado de que se pagarán las deudas, y que reformará los gastos de su casa, en lo que ya está trabajando, y han bendido quatrocientos caballos. Como al mismo tiempo han rebajado algo el pan, este pueblo está contentísimo, de modo que el día del Corpus en que fue el Rey a la procesión de la parroquia de Passi, lugar inmediato a la Moutte, aseguran que fueron de París más de mil coches, y un pueblo inmenso por verlo. Lo mismo y mucho más hicieron con el difunto quando le hirió [Robert d'] Amiens, y huvieron de sacar al Rey a un balcón para que lo vieran y se retiraran porque creían que estaba muerto y que los engañaban; y quando ha muerto no se les ha dado un pepino.

El día 13 marcha la Corte a Compiegne, a donde iremos nosotros dos o tres días después, lo que me sabe muy mal, porque estaremos allá hasta fines de agosto» ${ }^{63}$.

Respecto a los cambios ministeriales en el Gobierno francés, el propio Aranda había escrito también a Roda que: «Con un medio de entre nuestras dos cortes, que en una saltan fácilmente los ministros, y en otras se mantienen algunos demasiado, concibo que las dos estarian mejor.

Que me haya de tocar en todos los destinos el allarme en las peores ocasiones parece una suerte decidida que me persigue. Ya tenía hechas mis labores con las que avía de tratar, y el difunto soberano me estimaba, quando ahora vida nueva y hecharme a pulsar en tan críticas circunstancias, sin saber uno como pensarán los que entran en cabeza y manos» ${ }^{64}$

Pero el boato principesco que Aranda imprimió desde el principio a su representación diplomática -y en el que invirtió buena parte de sus rentas ${ }^{65}$ - volvería a brillar sobremanera con ocasión de las jornadas del nuevo soberano en Marly durante el mes de junio. Mientras que, según decía Aranda, Heredia tendría ocasión de pasear «como un condenado», el Conde se disponía para «tener muchas gentes para tratarlas y captarlas a la moda del país» ${ }^{66}$.

63. [Heredia - Roda], París, 6 de junio de 1774.

64. Aranda - Roda, París, 6 de junio de 1774 [Autógrafa].

65. «En sus catorce años de embajador en Paris (1773-1787) había dejado,... un perdurable recuerdo de faustosidad y lujo cuya traducción práctica fue una constante sangría, por lo que, como decía él con humor, tuvo que dar bastantes "pellizcos" a sus bienes. (...) Entre ellos merecen destacarse los siguientes: en 1775 arrienda todos los bienes raíces que posee en Maella, al año siguiente vende la facultad de cortar pinos en las heredades catalanas de Santiga y de Caldes de Montbui, en 1780, vende a carta de gracia la casa heredad de Marata (situada en Gerona), por los mismos años arrienda las minas de cobre y de alumbre en Susqueda, y en 1793, siendo ya decano del Consejo arrienda los bienes de la baronía de Gavin». MORENO MEYERHOFF, Pedro: «Genealogía y patrimonio de la casa de Arandas, en El Conde de Aranda Zaragoza 1998, pp. 53.

66. Aranda - Roda, Marly, 19 de junio de 1774 [Autógrafa]. Y añadía: «No me embidie VE. en esta ocasión, bien que en todo lo demás es una gran vida». 
Poco después Heredia describía la actividad desplegada por Aranda, «teniendo mesa todos los dias, muchas cenas, y desde oy asamblea general todos los dias desde las tres de la tarde hasta las nueve de la noche con mesas de juego, licores, vinos y sorbetes a discreción ${ }^{67}$, festejos que resultaron un éxito, pues -conforme escribía Heredia- concurrieron a ellos «todas las personas reales. El Rey una vez, la Reyna y sus cuñadas cinco; las tías dos; y los Condes de Probenza y Artois seis o siete; y a excepción del Rey que dixo no estaba acostumbrado a los elados, todos los demás comian y bebían quanto les daba la gana» ${ }^{68}$.

Aranda y Heredia regresaron a París el 25 de junio, pues estaba previsto que el 27 se celebrasen los funerales solemnes por el rey difunto con la asistencia de «...quarenta y dos obispos, cinco más entre el predicador y oficiantes, y quatro que no pudieron concurrir por enfermos. Todos estos monseñores se hallan en la Corte y París, pues no se hace benir a ninguno de sus diócesis para dicha función ${ }^{69}$. "Las exequias se celebraron con gran magnificencia en San Dionis el 27 de junio; pero el sermón, que acostumbraba imprimirse inmediatamente, no se ha dado aún al público, porque el Obispo de Sener que lo predicó, satirizó cruelmente en algunos pasages al difunto, y a sus Ministros, y hablo mal de la extinción de la compañía. Este mismo orador predicó la quaresma pasada al Rey, siendo abate, y en el sermón de Pasión dixo cosas terribles contra el descuido y abandono del Rey, y contra sus Ministros y cortesanos; $y$ cuentan que en una de estas rociadas se bolvió el Rey al Duque de Richelieu y le dixo: "Monsieur le Maréchal c'est pour vous". Se dice que no se permitirá imprimir sin que se enmiende, pero se duda si querrá reducirse a ello el Obispo. Entretanto, embio a V.E. el que predicó sobre el mismo asunto a la Academia el abate Boismont, que ha merecido aplauso, sin embargo de que habla con la mayor claridad contra los Ministros, y contra los que estaban cerca del Rey en su última enfermedad. La pintura que hace del carácter del Rey es la más verídica y exacta que se puede imaginar; y muchas veces sucedía en el Consejo que depués de haver hablado los Ministros sobre un asunto, les hacía ver lo contrario con sólidas razones, y concluía con que se hiciera lo que ellos opinaban; y aún algunas veces añadía, "es un gran disparate, ya lo verán"»".

Con todo, la impresión de los dos aragoneses era que el relevo en el Gobierno no afectaría en lo sustancial a las relaciones hispano-francesas: «Hasta aquí todas las apariencias son faborables al sistema de nuestra unión, pues el Rey y el Ministro interino [Henri-Leónard Bertin, que lo ocupaba hasta la incorporación de Vergennes,

67. [Heredia - Roda], Marly, 2 de julio de 1774.

68. [Heredia - Roda], París, 4 de agosto de 1774.

69. [Heredia - Roda], Compiegne, 15 de agosto de 1774.

70. [Heredia - Roda], París, 4 de agosto de 1774. La aparición del sermón impreso se dilató hasta agosto, y el 15 de ese mes remitía Heredia un ejemplar al Secretario de Gracia y Justicia: «Remito a V.E. un exemplar del sermón del Obispo de Sener, que se ha impreso con la supresión de pocas palabras de ninguna imponancia, según lo ohi a uno que havía visto el original». 
entonces Embajador en Suecia] se han explicado muy persuadidos de su importancia» ${ }^{7 !}$.

El 5 de agosto, despejado el panorama de los males que habían afectado a tres de las princesas, el Conde y parte de su séquito se trasladaron a Compiegne, donde los ágapes organizados por cuenta de Aranda volvieron a resultar fastuosos a costa de su propio bolsillo. Heredia narraba el triunfo que había vuelto a representar para el Conde la asidua participación de las personas reales: «La Condesa de Noilles, Camarera mayor de la Reyna, dixo a S.E. que su Ama tendría mucho gusto en que diera una función en el bosque que ay en este sitio, y combidara a las damas de la Corte. Se tuvo dicha función el sábado pasado por la tarde, en una gran sala que se hizo capaz de contener 500 personas, y en la que, a un mismo tiempo, se jugó en 16 mesas, sin embarazar el paso para serbir los refrescos. La Reyna y sus quatro cuñadas llegaron a las cinco de la tarde; y poco después los Condes de Provenza y Artois, y estuvieron hasta las ocho y media haviendo jugado todas las Princesas. El concurso fue inmenso, y lo calculaban los mismos franceses de quatro a cinco mil personas entre la gente de distinción y el populacho, que acá se mete a la vista de las personas reales con la misma libertad que ahí los que las sirben, y entraban y salian en el salón sin que nadie se los embarazara porque no quiso S.E. que se pusiera guardia en ninguna parte. El Rey estubo de caza aquella tarde y salió con deseo de poder dirigir el cierbo a aquella parte para poder concurrir, pero tubo el chasco de que tomó la ruta opuesta. Mañana y el sábado se repetirá la misma función, y el Rey irá mañana (...) La Corte se irá a Versailles el 2 de se[p]tiembre, y nosotros a París el 29 de éste» ${ }^{72}$.

La preocupación por el contagio de viruelas que había afectado a las princesas Adelaida, Sofía y Victoria poco después de la muerte de Luis XV, hasta que quedaron fuera de peligro en los primeros días de junio ${ }^{73}$, fue abordada desde el punto de vista de la nueva ciencia médica, y la inoculación llegó a convertirse en prácticamente una moda de la sociedad elegante.

El 10 de junio Aranda ya había hecho a Roda un vaticinio acerca del impacto que causaría en Madrid la noticia que había remitido por extraordinario de haberse sometido a la inoculación el conde de Provenza y los condes de Artois, y la de que el propio Luis XVI se sometería a ella: «Aí se aturdirán de ver tantos correos de acá; creherá el público, que se revuelbe el mundo, y avrá discursos en las librerías de la puerta del Sol a montones» ${ }^{74}$

Mientras las princesas convalecían en Compiegne, en Marly la familia real y la mayor parte de los cortesanos se sometieron a la operación siguiendo el ejemplo de Luis XVI, y no sin alguna retranca escribía Heredia: «Vamos ya tocando el término

71. [Heredia - Roda], Marly, 2 de julio de 1774.

72. [Heredia - Roda], Compiegne, 23 de agosto de 1774

73. «Choisy 2 de junio de 1774. Se han terminado felizmente las enfermedades de Madamas [Adelaida] Sofia y Victoria de forma que tenemos la satisfacción de anunciar el total restablecimiento de las tres Princesas, cuya conservación interesa a todo el Reino". Gaceta de Madrid, 21 de junio de 1774.

74. Aranda-Roda, París, 10 de junio 1774. [Autógrafa]. 
de la inoculación de estos Señores que ha sido en todos sus periodos muy feliz. Ellos se han paseado y disfrutado sus diversiones ordinarias todos los días, y el Rey ha acudido a los Consejos y tenido sus despachos como antes, y no se resolbió a inocularse hasta que los médicos le aseguraron de que no le impediría el despacho, lo que prueba su grande deseo y aplicación al govierno de su reyno. Con este exemplar no quedará ya francés que no se inocule, y acá estamos rodeados de cortesanos de ambos sexos que, con pretexto de que tuvieron pocos granos quando las tuvieron naturales, o quando se inocularon, han repetido la operación sin efecto, y de alguno he oído que lleba ya quatro inoculaciones. Tengo por cierto que ellos llegarán a comunicarnos este méthodo por vía de moda, y que será más útil a la nación que las otras que nos pegan» ${ }^{75}$.

Pero una de las principales cuestiones políticas que tenía planteada Francia en aquellos momentos, además del sempiterno problema financiero, superaba el marco estrictamente coyuntural del relevo en los Ministerios para adentrarse en la definición constitucional del reino y el estatus de la Corona y de los Parlamentos, pues, en definitiva, más que de un conflicto de competencias, lo que se perfilaba era una verdadera pugna entre el absolutismo monárquico y las fórmulas parlamentarias desde el coup d'Etat Mapeou de enero de 1771: «El asunto del restablecimiento del antiguo Parlamento -escribía Heredia el 30 de septiembre de 1774- que se esperaba de un día a otro no ha salido todavía, y como estas gentes en todo obran por impetu se les ha calmado ya la furia, de modo que apenas hablan de ello. Sin embargo, el negocio se trata entre los Ministros, y no lo han resuelto ya porque no han podido acordar los diversos intereses de los partidos encontrados, ni hallar el modo de hacerlo con

75. [Heredia - Roda], Marly, 2 de julio de 1774. La Gaceta de Madrid del 28 de junio recogía Ja decisión de Luis XVI de inocularse en Marly, pues en Compiegne se hallaban convalencientes las princesas. La del 5 de julio de 1774 recogía la noticia de la inoculación de la familia real francesa en los términos siguientes: «Marly, 19 de junio de 1774. El Rei, Monsieur y los Sres. Condes de Artois fueron inoculados ayer a las ocho de la mañana, después de haberse preparado en debida forma. Se ha tomado la materia virolenta de un niño de dos años, cuyas viruelas eran de las que llaman vulgarmente locas y de la mejor calidad. Los Médicos han reconocido con el mayor cuidado la salud del niño, y también la de sus padres: el Magistrado ha hecho también por su parte las más exactas averiguaciones, y de todo se ha tomado testimonio». La del 19 de julio decía: «Marly 3 de julio de 1774: Si la Nación, que tanto ama a sus Soberanos fuese menos instruida y hubiera podido tener el menor rezelo acerca de la valerosa resolución tomada por el Rei, por sus augustos hermanos y por la Sra. Condesa de Artois de sujetarse a la inoculación, presto se habría desvanecido con las reiteradas noticias que se recibian del feliz éxito de esta operación. Tenemos en el día el consuelo de saber se hallan Su Magestad y Altezas enteramente restablecidos, Libertándonos para siempre del sobresalto de perderlos por la cruel enfermedad que acaba de arrebatarnos al amado Monarca Luis XV, y amenazó a un tiempo las vidas de tres Princesas, se han hecho más recomendables a la Francia por sus grandes virtudes. Dichas princesas vinieron aqui desde Choisy el día 26 del pasado, y fueron recibidas por los Reyes y la Familia Real con demostraciones del mayor júbilo. Los Príncipes y Princesas de la Sangre, los Ministros y Secretarios de Estado, y los Caballeros y Damas de la Corte tubieron el día siguiente la honra de cumplimentar a Sus Magestades y Altezas, con motivo de su pronta y feliz convalecencia». 
decoro del Rey. Veremos en que para este grave asunto que, ciertamente, ésta lleno de grandes dificultades ${ }^{76}$.

Heredia tampoco dejó de lado las noticias acerca de las cábalas para la formación del nuevo gabinete ministerial. La dimisión d'Aiguillon de las carteras de Estado y Guerra fue cubierta con el nombramiento del entonces embajador en Suecia, conde de Vergennes, haciéndose cargo interinamente hasta su incorporación Mr. Bertin, mientras de la cartera de Guerra se hizo cargo desde el mes de junio el conde de Muy, y el 22 de julio el exintendente de Limoges, Mr. Turgot, prestaba juramento de su nuevo cargo de Secretario de Estado de Marina, antes de ocupar el empleo de Controleur Géneral. Mr. Joly de Fleury sustituía en septiembre al abate Terray en el empleo de Secretario de las Órdenes del Rey, y Armand de Miromesnil era presentado al Parlamento como Guardasellos de Francia en noviembre de ese mismo año"

Tras un silencio en la correspondencia de casi dos meses, entre el 30 de septiembre y el 20 de noviembre de 1774, Heredia proporcionaba Roda las primeras informaciones acerca del restablecimiento del Parlamento: «Hace ocho días que estamos aguardando la impresión del Lit de justice que se tuvo el 12 del corriente para despachar el correo con el que contaba embiarle a V.E. un exemplar, quando al bolver a casa a las diez. de la noche me hallo con que S.E. ha resuelto que marche el correo mañana por la mañana con dos exemplares que le han ofrecido le embiaran muy temprano, lo que me imposibilita poderlo remitir ahora, pero sí lo bende mañana lo remitiré por el correo.

Diré a V.E. lo más sustancial de los varios decretos que se publicaron en él. Primeramente se ha restablecido el antiguo Parlamento al mismo pie.

En este momento me embía S.E. un exemplar para mí, y lo incluyo a V.E., con lo que omito la relación que havía empezados ${ }^{78}$.

En la misma ocasión Aranda pintaba un cuadro político con más colores que lo había hecho Heredia. Para el Embajador el Lit de justice era, en substancia «un pastel, aunque parece bien puesta la autoridad real haciéndose absoluta en la maniobra. [i]Pero subsistirá?

A buena cuenta el rey reconoce la inamobilidad, que era lo que sostenía el Parlamento desterrado; pues vuelbe esta todo en cuerpo, sin mezcla con los que lo avían remplazado, y con los mismos despachos cada miembro, sin aver si quiera precabido esta esencial circunstancia, con recoger los nombramientos antiguos, y darles otros nuevos.

Con el exemplar ya no encontrarán quienes en igual caso se presten a admitir las plazas, y aunque parece suplido con aver declarado el Gran Consejo habilitado para juzgar en falta del Parlamento; este puede ser un quid pro quo de boticario para el de París, pero no para las provincias, donde aún a ido peor la maniobra.

76. [Heredia - Roda], París, 30 de se[p]tiembre de 1774.

77. Gaceta de Madrid de 28-6-1774, La Muette, 12-6-74- Ibíd. 9-9-74, Marly, 24 de julio de 1774; Ibíd. 11-10-1774, Versailles, 22-9-1774, Ibíd. 14-11-1774, París, 14-11-1774.

78. [Heredia - Roda], París, 20 de noviembre de 1774. 
Si todos vuelben a un tiempo a jugar alguna morisqueta, $[i]$ quien los sujetará, seguros de que nadie se atreverá a remplazarlos? Entonces dirán que fué violencia quando los suprimieron el año 71, que fue otra tal con la que les obligaron a registrar en 74 quando los restablecieron: y los letrudos [sic] traviesos de este país que saben mui bien tergiversar las cosas, imagínese V.E. como lo pintarán de oro, y azul» ${ }^{79}$.

Las primeras noticias remitidas por Heredia en 1775 se centraron primordialmente de los sucesos protagonizados en el pulso entre el Parlamento y el Gobierno: «Ya havrá sabido V.E. como a principios del mes pasado combocó el Parlamento los Príncipes y Pares para proponerles si debia representarse sobre lo establecido en el Lit de justice, y que contra la opinión de los hermanos del Rey, a quienes sólo siguieron pocos Príncipes y Pares, todo el resto opinó que se bolbieran a juntar el 30. En efecto, lo exequtaron, y aunque la ocupación de estos días en el despacho de este correo no nos ha dado lugar a averiguar las particularidades de lo ocurrido en la asamblea, se sabe que resolbieron representar sobre la mayor parte de los decretos registrados en el lit de justice. Esto hace ver que este negocio no está aún acabado, y si el Parlamento llega a conocer la debilidad en el Rey hará de las suyas como por lo pasado; por lo que haviendo quitado la venalidad en las plazas y dejándolas sobre el pie en que las puso el Canciller, lo que en todo tiempo haría dependientes del Rey a los ministros, como sucede ahí, siempre me ha parecido sumamente arriesgada esta operación, y en el mismo día que se publicó dixe a los de casa que como viva Maurepas no me causaría nobedad verlo desterrado por haver restablecido el Parlamento.

El espiritu de aristocracia que V.E. observa en los escritores modernos de esta nación es efecto de su ligereza, y de la manía que oy tienen de imitar a los ingleses, a que también ha ayudado mucho la irreligión; pero en la realidad nada combiene tanto a esta nación como un govierno vigoroso y de uno sólo, porque su natural es indócil y altivo, y no se acomodan a obedecer a quien no miran muy superior ${ }^{80}$.

El 25 de febrero tanto Heredia como Aranda aprovecharon otra de las «ocasiones seguras» para renovar a Roda su confianza. Mientras el Conde se apresuraba a lanzar algunas sentencias a la aragonesa ${ }^{81}$, a Heredia le tocaba ser más explícito. «Su-

79. Aranda - Roda, París, 20 de noviembre 1774. [Autógrafa]. Oro y azul eran los colores de la orden del Santo Espíritu.

80. [Heredia - Roda], París, 3 de enero de 1775.

81. "Por ser ocasión segura, la aprovecho para renovar a V.E. mi afecto a su persona. Creo que también Don Iñigo la aproveche; lo que puedo decir a V.E. es, que se pasa gran vida, lee, y pasea hasta quitarse el pellejo.

Esta corte como de niños, y entre una nación toda de calaberas puede imaginarse V.E., como será. Es un teatro totalmente diferente del de Luis 15; bien que cada uno por su término a qual peor.

Con que hai Papa el Cardenal Braschi, hechura de Ganganelli, pero [i] también del partido Rezonico? Veremos como pinta.

Escrive el Abate Pico a Beliardi, que Grimaldi se da por cansado, diciendo querer soltar la carga; pero el mismo Pico da a entender, que no lo crehe. Sea lo que fuere el tiempo nos lo dirá.

Me intereso mui de veras por el abogado Cantero uno de los mejores de Madrid; creo que huviera hecho un gran teniente de Corregidor, y está cortado para qualquiera fiscalía. Pido a V.E. lo proteja, y atienda; $y$ si se le presenta, lo honrre. 
pongo -escribía Heredia- que ya se hallará V.E. instruido del paradero que tuvieron las representaciones del Parlamento, las quales estaban concebidas en los mismíssimos términos y en las mismas razones y máximas que ocasionaron su destrucción en tiempo de Luis 15. He reparado en muchas gacetas estrangeras que quando copian la respuesta del Rey, y la resolución o arreté que sobre ella tomó el Parlamento, se dejan en el tintero lo más fuerte del arreté. Tengo muy presentes la de Colonia y Dospuentes que lo truncan, lo que puede ser haya sido por influxo de esta Corte, pues se aseguró entonces que el Rey havía quedado muy sentido de esta resolución. Quien lo trahe cabal es el Diario político de Bullon que embié la semana pasada a la Secretaría» ${ }^{82}$.

De vez en cuando Heredia le trasmitía alguna noticia jocosa relacionada con la maledicencia con que los libelistas acogían algunas decisiones políticas. El 30 de marzo de 1775 se hacía eco de los chascarrillos a que había dado pie la designación de siete Mariscales de Francia: «Hace quatro o cinco días que el Rey ha hecho siete mariscales de Francia, y son el Duque de Harcourt, el Duque de Noilles, el Conde de Noilles, el Conde de Nicolai, el Conde de Mui, Secretario de la Guerra, el Duque de Fitz-James y el de Duras; y como estas gentes gustan mucho de la plaisanterie les han aplicado el apodo de los siete pecados mortales, atribuyendo a Harcourt la pereza; al Duque de Noailles la embidia; al Conde la sobervia; a Nicolai la gula; a Mui la ira; a Fitz-James la avaricia y a Duras la lujuria.

No ay otra cosa particular, ni tengo la cabeza para más por hallarme muy resfriado» ${ }^{83}$.

El nuevo reinado daba comienzo con dos medidas de largo alcance, pues a la restauración del Parlamento, le había precedido también la publicación el 13 de septiembre del decreto por el que se restablecía la libertad del comercio interior de granos y harinas, que se había ensayado desde mayo de 1763, y luego suspendido en 1770 . El decreto restablecía el libre comercio interior salvo en París, declarando expresamente que no se harían más compras por cuenta del erario real para la provisión de distintas ciudades y provincias, salvo la capital del reino, fomentando las importaciones y dejando en suspenso las medidas acerca de la exportación de granos franceses ${ }^{84}$.

A pesar de la creciente imagen de «desorden» en Francia, el diagnóstico que realizaba Heredia era bastante optimista y, en los primeros días de mayo de 1775 se refería a la guerra de las harinas y los alborotos provocados por la carestía del pan: «Este

Acedo está mui reconocido a V.E. y lo considero hombre de conservar su gratitud a sus bienhechores.

[i.] En qué está lo de colegios maiores? Ahora con el nuevo Inquisidor a la mano se podrá mejor concluir essa grande obra.

V.E. cuente con que inalterablemente soy su apasionado, sobre esto mande sin reserva, y experimentará que es su verdadero servidor». Aranda - Roda, París, 25 de febero de 1775 [Autógrafa].

82. [Heredia - Roda], París, 25 de febrero de 1775.

83. [Heredia - Roda], París, 30 de marzo de 1775.

84. Gaceta de Madrid, 10-10-1774. París, 3-10-1774. 
Reyno se halla en la mismissima situación que estubimos nosotros el año de 66, pues con motivo de la escasez y carestía de granos se han sublevado muchísimos pueblos, y es regular que lo vayan continuando otros a vista del exemplo que les ha dado la Corte y la capital. En Versailles acaeció el motín el martes de esta semana, y se repitió el miércoles. En este día lo huvo acá y se reduxo a que desde las ocho de la mañana empezaron los amotinadores a apoderarse del pan de los mercados, y del que havía en todas las casas de los panaderos, con la diferencia de que los más se lo llebaban de valde, y otros lo pagaban al precio que se fixaron de dos sueldos la libra, reduciéndolo de tres y medio a que estaba. En la alóndiga empezaron a saquear la harina, pero fue poco el daño porque los contubo la tropa que fue llegando de todas partes. Se ha dicho que huvo algunas desgracias, lo que no ha podido saberse de cierto.

Desde el medio día del miércoles pusieron dos soldados en cada casa de panadero, y subsisten aún. El juebes se publicaron carteles en que de orden del Rey se mandaba pagar el pan al precio corriente de tres sueldos y medio, y se daba facultad a la Prebosté (especie de jurisdicción militar) para proceder contra los perturbadores. En el mismo día a solicitud del Contralor general escribió el Rey al Parlamento que se abstuviera de mezclarse en este asunto; y haviendo deliberado el Parlamento sobre la orden la mañana del juebes resolbió que se fixara en las esquinas un arresto, que, según dicen, se reducía a co[n]minar [a] los amotinadores, y a expresar que representaría al Rey para que mandara bajar el precio del pan. Este arresto se supone que se fixo al anochecer de aquel día, y haviendo llegado en la misma noche la noticia a Versailles, a los doce y quarto hizo llamar el Rey a Maurepas, al Guarda Sellos, al Duque de la Vrèliere [sic], y al Contralor, y haviendo conferido con ellos resolbió tener al día siguiente un lit de justice en Versailles, el que se tuvo ayer entre tres y quatro de la tarde, y la substancia de lo que en él se ordenó se continue en el adjunto papel, en el que igualmente está copiado un cartel insolente que se halló fixado el miércoles en el rexado de un combento de dominicos. Los arrestos del Parlamento los arrancó la tropa de las esquinas, y al impresor le mandaron entregar los exemplares que tenía, y desacer la tabla en que se havian impreso.

Al día siguiente del motín quitaron los empleos a Mr. le Noir, Lieu-tenant de Police, y al Comandante de la tropa que llaman el Guet, y suponen que ambos han sido sacrificados por el Contralor, a quien atribuyen las probidencias que se han tomado, y a quien pintan encaprichado del sistema de la libertad del comercio de granos, y capaz de dar con todo al traste por sostener su idea. Para burlarse de él, y de una Marquesa d'Anville, gran protectora suya, y tan fanática como él, han publicado una estampa en que dicen estan pintados los dos con el trasero descubierto, y un rótulo que dice sobre sus nalgas "Libertad". Lo cierto es que por confesión del Govierno, en el último decreto del Consejo que se publicó hace como 12 días, la cosecha ha sido mediana y suficiente para la manutención del todo el Reyno; y con todo desde el momento en que, a instancia del Contralor, se derogaron la reglas del reinado pasa- 
do sobre el comercio de los granos, empezaron los alborotos en las provincias y no ha cesado de subir el precio.

Aquí se ha dado el mando de la tropa al Mariscal de Biron, Coronel de Guardias francesas, y se esperan de día en día varios Regimientos. Se ha mandado a los Comandantes e Intendentes, que por prescripción tienen ganado el derecho de comerse sus sueldos en París, que vayan a sus destinos; y como son tantos los pueblos amotinados casi todo el exército está en movimiento. Todo esto pasará como una nube de verano» ${ }^{85}$.

La polémica acerca de la libre circulación de granos se convirtió en el centro del debate político ${ }^{86}$. «Sobre granos se ha encendido aquí nuevamente una guerra literaria después que el actual Contralor general se ha declarado protector de los Economistas, de cuya sociedad estará V.E. tal vez instruido. Estos son acérrimos defensores de la libertad del comercio. El primero que los atacó fue Galiani, y después Linguet los satirizó cruelmente en su respuesta a los doctores modernos; y en el ministerio de Feurai [sic] estuvieron muy abatidos. Luego que empezó el actual govierno bolvieron a inundar de papeles el público, y dieron a luz la respuesta a Galiani que suponen no se la permitieron imprimir en el tiempo inmediato a la publicación de la obra de Galiani; y se bengaron de Linguet en la Broehure [sic] que escrivió el Abbée Morlais de la Theorie du paradoxe, bien que éste no tardó 15 días en pagarles con obras en la respuesta que les dió en la Theorie du libelle. Algún tiempo después Mr. Necker publicó un libro sur la legislation et le commerce des grains ${ }^{87}$, en que se opone a los principios de los Economistas, adoptados por el Contralor, cuya obra metió mucho ruido y ha alarmado a los Economistas, que han empezado ya a combatirla pero con poco succeso hasta aquí.

Una vez pues que V.E. desea tener lo que se ha escrito de nuevo sobre este asunto, he comprado, la respuesta a Galiani, que no he leido; la obra de Necker, escrita con moderación y digna de leerse con reflexión; y la respuesta que ha dado a ella el Abbe Baudeau, que es el trompetero de los Economistas. Estos libros y los que pueda haver de los que V.E. me ha pedido, los iré embiando succesivamente por los correos, y al fin abisaré a V.E. su coste.

Empiezo por remitir en éste los Edictos del Govierno sobre granos, y la obra de Necker, el qual es ginevrés, y después de haver sido mucho tiempo uno de los famosos banqueros de esta Corte, hace años que su república lo nombró por su Ministro en ellar ${ }^{88}$.

85. [Heredia - Roda], París, 6 de mayo de 1775.

86. Una apretada síntesis de lo que representó el debate del libre comercio de granos en la Europa desde la segunda mitad de siglo en LLOMBART, V. Campomanes, economista y político de Carlos III, Madrid, 1992, pp. 156-163.

87. NECKER, Sur la législation et le commerce des grains. A Paris, chez Pissot..., 1775, 2 vols, constituía una crítica de las teorías fisiocráticas, y contrario a las medidas liberalizadoras reimpulsadas por Turgot desde 1774, y defendiendo la necesidad de la intervención de los poderes públicos.

88. [Heredia - Roda], París, 30 de junio de 1775. 
Naturalmente, el interés de Roda y Heredia por las polémicas en torno a la política liberalizadora no era circunstancial. Al igual que en Francia también se dio en España un recrudecimiento de las batallas políticas en torno a la liberalización del comercio interior, pues, conforme hacía notar Vicent Llombart, la oposición al libre comercio, sobre todo después de 1767, «aparece esencialmente en el seno de la propia administración ${ }^{89}$.

Desde el mismo del Consejo de Castilla se intentó una ofensiva contra las medidas liberalizadoras impulsadas por Campomanes. Heredia, que tras haber escrito una furibunda carta a Roda el 16 de agosto, por vía segura, se mostraba más discreto y «moderado» en otra que por el correo ordinario remitió el día 17 , se refería a este intento que consideraba involucionista y desatinado: «No puedo hablar a V.E. con igual moderación de la consulta del Consejo sobre granos, de la que he leído un extracto bien circunstanciado. Sin meterme a defender la libertad del comercio interior, por considerar este punto lleno de grandes dificultades por una y otra parte, me atrebo a decir que la preocupación en que se hallaban sus individuos contra la libertad del comercio, quando entraron a examinar este asunto, los cegó de modo que no vieron la luz que ellos mismos se pusieron delante de sus ojos. De los estados que producen en la consulta resulta que en los nueve años que ha havido la libertad del comercio han sido mucho menores los diezmos que en los nueve anteriores; y lo que es consiguiente, que las entradas de granos extrangeros han sido mayores en los primeros que en los segundos. De este principio deducirá naturalmente todo el mundo que haviendo sido menores los diezmos han sido menores las cosechas; y no probándole que la escasez de las cosechas ha dimanado de no haver podido sembrar los labradores a causa de falta de trigo, o de correr a un precio tan alto que no han podido comprarlo, y que esta altura la ha ocasionado el libre comercio; no le ocurrirá echar a éste la culpa de la escasez de las cosechas, sino que la atribuirá a las causas naturales que tan frequentemente se repiten a su vista. Pero el Consejo, sin entrar en ninguno de estos puntos, hecha toda la culpa al libre comercio, y a esto se reduce la consulta» ${ }^{90}$.

Mientras tanto, aparentemente al menos, la vida en la Corte francesa continuaba con toda su magnificencia exterior, sobre todo con ocasión de visitas de trascendencia internacional o la celebración de los enlaces de la familia real.

En el primer caso, el gran acontecimiento político-social de 1775 fue la visita a París del archiduque Maximiliano, que movilizó al todo París, y naturalmente al Embajador de Su Majestad Católica: «Desde el 7 del corriente tenemos acá al Archiduque Maximiliano, y dicen que partirá para Viena el 2 de marzo. Todo el tiempo que ha estado aqui ha dibidido su estancia entre Varsailles y París, permaneciendo en Versailles los quatro primeros días de la semana, y en París los tres restantes, en donde ha ido viendo lo que ay de más particular. El 17 lo combidó a comer S.E., y le

89. LLOMBART, V. Campomanes, economista y politico de Carlos III, Madrid, 1992, pp. 155-190, cit. p. 179.

90. [Heredia - Roda], Sin fecha. [17 de agosto de 1775]. 
tuvo por compañía los embaxadores y ministros estrangeros; los ministros de esta Corte; los mariscales de Francia; y los gefes de palacio; de modo que eramos sesenta de mesa; pero el Archiduque no come otra cosa que huevos, mucho pan, berduras $y$ frutas, y no bebe vino. Aunque el Rey y sus hermanos lo han cortejado mucho creo que asi él como su hermana la Reyna estarán poco satisfechos por no haver querido visitarlo los príncipes de la sangre, los quales han pretendido que primero debía visitarlos él una vez que sólo se presentaba como Conde de Bourgau, y que así lo havía hecho el Rey actual de Suecia; pero el Archiduque no ha querido dar este paso, y se dice que la Reyna está sumamente picada contra los príncipes» ${ }^{\circ}$.

La Corte había brillado también en todo su esplendor con motivo de la boda de la princesa Clotilde. El 20 de agosto anunciaba a Roda que: «Mañana vamos a Versailles al matrimonio de la Princesa, y pasaremos toda la semana en fiestas, pues ay tres días en Versailles, y dos aquí del Embaxador de Turín» ${ }^{92}$.

Pero, en esta ocasión, el viaje a Versailles fue muy perjudicial para la salud del voraz aspirador de rapé que era Aranda. De regreso en París, el 25 de septiembre de 1775, Heredia daba cuenta a su paisano Roda de los pasajeros alifafes que aquejaron al Conde: «Como la indisposición de S.E. no fue cosa de cuidado, y sólo efecto natural de quando se le retarda demasiado la evacuación de la sangre de espaldas, no le avisé a V.E. ni a ningún otro por no alarmar. En el día está enteramente recobrado, $y$ ha leido la carta de V.E. que ha benido por el correo francés» ${ }^{93}$.

A finales de $1775 \mathrm{al}$ «espíritu de aristocracia», a las dificultades en los abastos y la discutida política de reforma económica, a la permanente crisis de las finanzas reales había que añadir también las tensiones con y entre las distintas facciones del clero francés: «Ya sabe V.E. que a consulta de la comisión que aquí se formó para la reforma de los regulares estableció el Rey en años pasados que no pudiera hacerse la profesión religiosa hasta los 21 años. Los frailes han acudido a la Asamblea del Clero pidiendo su mediación para que se reboque esta providencia como destructiba de su subsitencia. La Asamblea se ha dividido en dos facciones. Una del Arzobispo de París en fabor de las religiones, y otra del de Tolosa, que es el corifeo de la Comisión, en contra; $y$ ha venido la primera de dos votos haviendo sido 33 contra 31 . En su consecuencia fueron la semana pasada los Diputados del Clero a entregar al Rey la representación que le hace sobre este asunto; pero se dice que el Rey no condescenderá a la solicitud del clero» ${ }^{94}$.

91. [Heredia - Roda], París, 25 de febrero de 1775.

92. [Heredia - Roda], París, 20 de agosto de 1775.

93. [Heredia - Roda], París, 25 de se[p]tiembre de 1775.

94. [Heredia - Roda], París, 12 de Diciembre de 1775. También Aranda escribió a Roda sobre el proyecto de reforma de las ordenes regulares: «Para que S.E. se divierta con la idea de la reforma general de frailes, reduciéndolos a quatro cuerpos no más; le incluyo una gaceta que en el artículo de Cleves pone la especie como proyecto del Papa. Qualquiera da estas volanderas aunque tenga muchos cabos sueltos, no deja de contener algo de bueno: y el tiempo con su transcurso, y la confusión de tantas legiones claustrales, no dejará de recoger tantos específicos como se como se van produciendo, para 
Los juicios de Aranda y de Heredia acerca del desorden imperante en la monarquía francesa se repiten una y otra vez: «Este Ministro de la guerra continua en hacer "main basse" de todos los abusos que va descubriendo en su ramo. Acaba de reformar la Escuela Militar, que era la admiración de todos los que no ven las cosas sino por la apariencia; y se ha ajustado con los benedictinos para que eduquen los muchachos, hasta cierta edad, en sus colegios. El famoso hotel de los Imbálidos dicen que está también "sur le tapis" para correr la misma suerte. Es increible el desorden que ay aqui en todos los ramos, y yo acostumbro a decir que nuestra casa esta arreglada como un combento de capuchinos comparada con esta» ${ }^{95}$. Ya en la primavera de 1776 concluía respecto a la reorganización militar francesa que el «Ministro de la Guerra tiene ya formado y despachado con el Rey su reglamento del pie en que ha de quedar el exército, y se publicará en breve. Todos combienen en que lo pone sobre ciento y ochenta mil hombres de infantería, y 45 mil de caballería» ${ }^{96}$.

La correspondencia podía quedar interrumpida durante algunos meses, dependiendo, según las ocasiones, del trabajo que tuvieran los corresponsales. «No he escrito a V.E. desde la última que recibí de V.E. por no haver tenido cosa particular que decir; y porque con el viage inopinado de Marly, y los negocios que después han sobrebenido no he tenido tiempo para nada. En el mismo día que nos trasladamos a Marly recibió S.E. orden de tomar las cuentas a Mr. de la Corbiere sobre la negociación del préstamo para el canal de Murcia, y de hacer depositar en esta Tesorería del Rey los Billetes imbendidos y el caudal existente es su poder; y como era imposible que S.E. pudiera practicar estas diligencias desde Marly fue preciso que yo me bolbiera acá al día siguiente para evacuar este encargo, el que me ha ocupado mucho y todavía me dará que hacer.

El viage a Marly se havía contado que duraría tres semanas, que contadas desde el principio del sarampión del Conde de Artois, finalizaban el 28 de éste. Pero en carta que recibí anoche de S.E. me dice que el Conde de Provenza se havía retirado indispuesto a Versailles, y que se temía que fuera sarampión, lo qual si se verifica alargará otro tanto el viage, y si van cayendo poco a poco las demás personas reales no tendrá término» ${ }^{97}$.

El 5 de julio todavía estaba trastornada la Corte, esta vez con con el sarampión del conde de Provenza: «Recibí la de V.E. por el extraordinario, celebrando se mantenga V.E. sin nobedad. El viage de Marly continua a causa de la nueva cuarentena de tres semanas que ha ocasionado el sarampión del Conde de Provenza, y como dicen que Versailles está plagado de este mal, se ignora quando se restituirá allí la Corte. Viendo S.E. lo largo que iba el tal viage se bino acá la semana pasada para ver el estado en que llebábamos acá la toma de cuentas de la negociación del canal

formar una buena triaca: la lástima es, que en nuestros días no lo veremos». Se trataba del «Courier du Bas Rhin», n 77, Du mercredi, 22 septembre 1773.

95. [Heredia - Roda], París, 10 de febrero de 1776.

96. [Heredia - Roda], s.I. s.f. [H. primavera 1776].

97. [Heredia - Roda], París, 21 de junio de 1776. 
de Murcia, que fue lo que me hizo benir a esta Vila; y se bolbió a Marly el 2 de éste, quedando yo acá para continuar este negocio, que aunque me ha dado y da bastante que hacer, lo llebo con mucho gusto por ver que liberta de Marly» ${ }^{98}$.

El 6 de febrero de 1777 Heredia informaba con satisfacción del nombramiento de Aranda como Caballero de la Orden del Santo Espíritu: «En el capítulo que tuvo este monarcha de la Orden del Sto. Spiritus el día de la Purificación nombró Caballero de la orden a S.E., a quien cogió enteramente de nuevo el aviso que le comunicó por un correo el Conde de Vergennes; y con este motivo ha anticipado el embio del extraordinario, que lleba ésta, para dar la noticia al Rey y pedirle su permiso para aceptar esta gracia»" $"$.

Si el viaje del Archiduque a París en 1775 fue un acontecimiento relevante, la anunciada «visita» del Emperador en 1777 tuvo una dimensión político-social todavía mayor: «Ha buelto a renobarse la especie de la benida del Emperador, y se asegura que estará acá a mitad de abril» ${ }^{100}$. El 13 de abril anunciaba Heredia: «El Emperador entrará aquí dentro de pocos dias, pues ay noticia de su arribo a Munich. Dicen que se detendrá un mes, y que después viajará por las provincias de este reino, y empleará como tres meses en todo el viage. Viene a parar a un Hotel garni[é], y ha hecho tomar otro en Versailles, sin haver querido tomar el alojamiento que la Reina le havía propuesto fuera del palacio» ${ }^{101}$. El 10 de mayo comentaba: «Estas gentes están encantadas con el Emperador por su agrado y humanidad, pues se porta acá como el particular más desconocido sin que en la más mínima cosa haya querido parecer lo que es. No permite que le presenten a nadie, antes bien él se hace presentar a los sugetos de distinción que halla en los parages a donde va. Todo lo corre y examina entrando en las casas, aunque sean de artistas, en donde ay algo que cree digno de su atención. El miércoles de esta semana estubo en casa del Abate L'Epeé a ver su modo de enseñar los sordos y mudos» ${ }^{102}$.

Como ya hemos indicado en alguna ocasión anterior, a Heredia se le ponían los pelos de punta cuando se acercaba la hora de abandonar París camino a los sitios reales. El 19 de julio de 1777 mostraba su júbilo por haberse retrasado la marcha a Compiegne debido a «unas ligeras tercianas que ha tenido la Reina (...) se ha rebocado la orden, de lo que estoi muy contento porque nada tiene de agradable dicho sitio» ${ }^{103}$.

Desde este momento, la parte del león en la correspondencia de Heredia con Roda se la llevó, además de las cuestiones relacionadas con los libros, las recomendaciones y algunos que otros chismes, el desarrollo del conflicto entre Francia e Inglate-

98. [Heredia - Roda], París, 5 de julio de 1776. La Gaceta de Madrid del 25 de febero de 1771, recogía lacónicamente el nombamiento de Aranda en la sección Versailles, 8 de febrero.

99. [Heredia - Roda], París, 6 de febrero de 1777.

100. [Heredia - Roda], París, 22 de marzo de 1777.

101. [Heredia - Roda], París, 13 de abril de 1777.

102. L'EPEÉ, Charles M. (1712-1789) Institutions des sourdes et muets par la voie des signes methódiques, Paris, 1776 [Heredia - Roda], París, 10 de mayo de 1777.

103. [Heredia - Roda], París, 19 de julio de 1777. 
rra, al que España se sumó en 1779, tras fracasar los intentos conciliadores que Carlos III encomendó al embajador Almodóvar, mientras que los asuntos político-cortesanos de Francia quedaron minimizados.

\section{LAS COSAS DE ESPAÑA}

Las noticias sobre los aconteceres de la política española quedan, por lo general, subsumidas en asuntos de mayor calado, como sucederá con ocasión del famoso autillo de Olavide, el desastre de Argel y el relevo de Grimaldi en la Secretaría de Estado. No faltan, claro está, las referencias a acontecimientos de relieve, como la salud o el fallecimiento de personajes de la casa real ${ }^{104}$, las cuestiones jesuíticas o la reforma de los Colegios Mayores impulsada por Roda, y algunos permenores que afectaban a conocidos o amigos comunes.

Más interesantes que las cartas de Heredia resultan las primeras que envió al Secretario de Gracia y Justicia el mismísimo conde de Aranda ${ }^{105}$, pues presentan como característica principal la intención de mantener un prudente contacto informa-conspirativo con Roda, con la esperanza de arrancarle algún gesto de complicidad con su persona -y con su política - frente a la cábala que Aranda consideraba responsable de su destierro dorado a París, es decir el macarroni Grimaldi, la camarilla de los golillas y Campomanes, el díscolo Fiscal del Consejo de Castilla ${ }^{106}$.

A pesar de no disponer de las cartas de Roda, la mera lectura de las misivas del flamante embajador en París permite concluir que Aranda tuvo poco éxito en sonsacar información y obtener la complicidad de Roda a la hora de procurar su regreso a la Corte. Las cartas, notas y recados de Aranda, muy comprometidos en el año $1774^{107}$,

104. "Recibi la de V.E. de 7 del pasado con el sentimiento que V.E. puede discurrir nos causó la muerte del Infante, que nos tuvo atolondrados por algunos dias». [Heredia-Roda], [París, sin fecha. Primeros meses de 1774, probablemente abril] «Recibi la de V.E. por el extraordinario, el que nos sacó del gran cuidado en que nos havian puesto algunas cartas de Madrid, que se recibieron el correo del miércoles, en que suponían al Principe con tabardillo y resuelta la quarta sangría, lo que nos tenía sin sombras. [Heredia - Roda], París, 6 de junio de 1774.

105. Las cartas conservadas de Aranda en este atadillo de correspondencia abarcan desde el día $11 / 14$ de septiembre de 1773 al 22 de marzo de 1777.

106. "La supervisión del comercio de granos, la investigación del motín, el dictamen y expulsión de los jesuitas, las reformas administrativas (sindicos y personeros del común), Sierra Morena, la legislación agraria y un largo etcétera, son claras muestras de que los años siguientes al motín significaron uno de los momentos álgidos [sic] de la influencia política del asturiano, lo que naturalmente le hizo entrar en conflicto con Aranda -la otra personalidad fuerte de aquellos momentos». LLOMBART, Campomanes..., p. 178

107. «Mui Señor mio: Con la ocasión de correo que despacho, y bajo el pliego de mi muger que espero llegue intacto a sus manos, escrivo esta a V.E. diciéndole, que reciví la suya de 20 de diciembre a su tiempo regular, y es la última que ha llegado a mis manos.

He oido que aunque las máscaras públicas se han quitado, se permiten bailes nocturnos en casa. de un bailarín italiano llamado Fabri a 8 u 10 reales de entrada por cabeza. Una de las cosas que yo prohibí con orden expresso a la sala para que lo delase, y assí lo hacía, fueron los bailes de casa de los maestros de danzar, porque todos eran un putaismo como lo serán los de Fabri. No entiendo los escrúpulos. 
van perdiendo «calidad». Si en los primeros momentos el Embajador en París escribe con cierta ansiedad, y pone al alcance de Roda los medios para sincerarse sin peligro, el paso del tiempo las irá dejando reducidas a meras salutaciones y recados de cortesía, que muchas otras veces se limitaban a «recuerdos» recogidos en las cartas de $\mathrm{He}$ redia ${ }^{108}$. La realidad de su dorado ostracismo acabó por imponerse, y también las cortesías particulares se hacen cada vez más espaciadas en el tiempo hasta quedar reducidas, tras la elevación de Moñino, a vagos testimonios protocolarios durante los años siguientes. Sólo en aquellos momentos en que las atentas orejas del conde sintoniza-

Mucho tarda a salir el $3^{\circ}$ Fiscal vacante por la muerte de Mena; ahora no hai Presidente contra quien convenga escogerlo a garra.

Dígame V.E. si en su despacho se miran las cosas de mi tiempo con desagrado, y si después que yo partí ha notado V.E. explicaziones en mal o en bien.

Quanto digo aquí se me aprueba, y no han faltado asuntos fuera del común. Por lo que toca a los de por aí ni una palabra.

La idea de las quintas parece que se sostiene, temo mucho que han de ser la ruina del reino, siendo anuales, y han de causar muchos disgustos.

Es regular que me despachen extraordinarios a tres o quatro días de recivido éste; si V.E. quiere responderme, embie su carta a mi muger.

La que yo escrivo a ésta por extraordinario la embio a Don Bernardo del Campo, y mi muger las suyas en igual caso. Tengo por hombre de bien a Campo, y que assí se evitan azares.

En un paquete que también pasará a V.E. mi muger le embio unos almanaques; lea V.E. el de Versailles donde verá hasta los dropes de la casa real, y formará juicio del desorden de esta Corte: en inteligencia que en él no se comprenden los dependientes de ninguno de los infinitos sitios reales, ni palacios de Paris.

Con una remisión de libros que me dice Heredia está para hacer, remitiré a V.E. diferentes mapas útiles para el estado presente de Europa, y un árbol genealógico mui grande de la familia Borbón moderno.

Aqui me hallo hasta ahora bien recivido, y considerado. Nemo propheta in patria sua. Si V.E. oye que me muelan por aí los huessos, avísemelo para mi govierno, y hazerle ver la injusticia con que me acusen.

Sabe V.E. que he sido suyo, y lo seré deseoso siempre de sus órdenes para obedecerle su verdadero servidor». Aranda - Roda, París, 20 de enero de 1774 [Autógrafa].

108. Así, por ejemplo, el 6 de mayo de 1774 escribía Aranda con motivo de las viruelas que aquejaban a Luis XV: «Mui Señor mio: Aquí se puede decir bien a la vejez viruelas. [¿] Quien se lo podía esparar? Pero va bastante bien, y yo espero que salga.

Imaginese V.E. la gazapera de maitresse y sacramentos. La primera salió a una legua y media, y a una casa de campo del Duque de Aiguillon haze tres dias, donde se mantiene como la usma.

De lo segundo se habla, y no sé si llegará el caso.

Como no me han quedado correos del Rey, empiezo a despachar criados mios; el que va este viage se quedará aí para traherme unos cavallos; el que le seguirá tres dias después, me lo volverán a despachar, y estará prevenido de presentarse a V.E. por si me quiere escrivir.

No me ha venido mal rompimiento de cabeza con la droga de la de enfermedad, y es menester conducirse con mucha maña. Escudriñe V.E. si se dan aí por bien servidos, y adviértame lo que le parezca, pues la ocasión será segura con mi criado que ha de volber.

Creo que V.E. no dudará del inalterable afecto que le profeso, y que mandará con toda confianza a su verdadero servidor». Aranda - Roda, París, 6 de mayo de 1774 [Autógrafa]. 
ron con los mentideros madrileños a la hora de husmear las posibilidades de recobrar el favor político de Carlos III, las cartas de Aranda recuperan su intensidad ${ }^{109}$.

El desastre de Argel fue el ariete más certero empleado contra el marqués de Grimaldi, pero las espectativas políticas del conde de Aranda quedarían nuevamente frustradas con el nombramiento de José Moñino como Primer Secretario de Estado en 1776.

El desastre de Argel

Conforme escribían Olaechea y Ferrer Benimeli, la «veta militar de Aranda se puso nuevamente se manifiesto, durante su embajada de París, con ocasión de la desastrosa expedición española a Argel...» ${ }^{110}$, hasta el punto de apresurarse a enviar a España a sus edecanes Oquendo y Cornel, a pesar de que desde Estado no se le había informado de que el objetivo de la empresa sería Argel y no Marruecos "1".

De nuevo fue Heredia quien volvió a tomar sobre sí la tarea de informar con detalle de cómo se contemplaba el negocio desde su perspectiva: «Con las noticias que nos han llegado de la expedición que ahi se prepara ha tenido por combeniente S.E. el que se hallen en ellas sus edecanes Oquendo y Cornel, y en su consequencia han partido oy a las dos de la mañana en posta hasta Bayona, y de allí se trasladarán a esa Corte con la mayor brevedad que les sea posible; y concluida que sea la expedición se bolverán acá sino [sic] ay nuevo motivo que los detenga ahí. S.E. les ha prebenido que hablen libremente con V.E. de lo que aquí pasa; y como por lo que han visto, y han oido en nuestras combersaciones, tienen bastante idea de estas cosas, podrá V.E. quedar bien instruido» ${ }^{112}$.

Sin embargo, a juzgar por la correspondencia, Roda no se mostró muy propenso a confiarse a los edecanes de Aranda, pues el 10 de febrero de 1776 Heredia escribía:

109. «Por fin se fue Gerónimo; temo mucho que haya dejado indispuesto al amo contra sus mejores vassallos. Lo que no comprendo es, el porqué [sic] no entrará en Roma hasta el otoño, quando han sido todos sus deseos, y sin fin particular no lo hace, porgue me río del colorido de descansar.

Si V.E. no me quiere escrivir, lo dispenso; yo estoi bien seguro de su afecto, y más quiero me guarde las espaldas, que no el que me haga cumplidos. Mande V.E. a su verdadero afecto servidor». Aranda - Roda, París, 22 de marzo 1777. [Autógrafa].

110. OLAECHEA, R. Y FERRER BENIMELI, J.A: El Conde de Aranda..., I, $65-66$.

111. «Mui Señor mio: Sepa V.E. que estoi bueno, y para servirle a pie, y a cavallo.

No se sorprenda V.E. quando vea mis capitanes Oquendo, y Cornel que llegarán aí a mitad del mes de abril, pues con motivo del armamento escrivo esta noche para que S.M. les permita ir de voluntarios. Espero se les conceda, porque estando distantes muestran sus deseos de hacer mérito, y van a buscarlo sin perder tiempo. Se presentarán a V.E., quien confio los reciva favoreciéndoles. Después de concluido lo que haya, pido que vuelban acá.

Naturalmente escrivirá Don Iñigo a V.E. de quien yo me repito verdadero servidor». Aranda - Roda, París, 30 de marzo 1775. [Autógrafa]. Joaquín Oquendo y Antonio Cornel eran militares y protegidos de Aranda, que, según el coronel Cadalso, se caracterizaron por engañar al conde de Aranda desde los tiempos en que ocupaba la Presidencia del Consejo de Castilla Apud. OLAECHEA: «Ignacio de Heredia y su biblioteca», p. 230-231, citando a CADALSO, J. Escritos autobiográficos y Cartas. Londres, 1978. Ed. de N. Glendinning y N. Harrison, pp. 12-19. 187, 202-203.

112. [Heredia - Roda], París, 30 de marzo de 1775. 
«Por los capitanes Oquendo y Cornel supe que V.E. estaba bueno, y que quiso escribirme por ellos, y ya supuse que las muchas ocupaciones se lo havían impedido a V.E.» ${ }^{13}$

Mientras tanto Aranda continuaba tan espectante como ayuno de noticias e instrucciones acerca de la operación militar, puesto que todavía el 30 de junio Heredia confesaba a Roda que continuaban «esperando con impaciencia el correo que nos traiga la noticia de la salida de la esquadra, cuyo objeto no se nos ha comunicado hasta aquí, y es regular que nos lo abisen con extraordinario a fin de participarlo a esta Corte» ${ }^{114}$.

La escuadra española, comandada por Castejón, partió de Cartagena a finales del mes de junio, confiado el mando de las tropas de desembarco al conde de O'Reilly, quien ordenó el comienzo de las operaciones de desembarco en las costas argelinas el día 15 de julio, y la Gaceta de Madrid publicaba, convenientemente maquillada, la noticia del estrepitoso fracaso el día 18 de julio.

La noticia del descalabro sufrido en Argel «corrió como un reguero de pólvora», y en cierto modo, la opinión de Heredia es reflejo directo de la del propio Aranda. La responsabilidad final del entuerto fue a parar sobre las espaldas de G[rimaldi]: «La oportunidad de dirigir esta carta con toda seguridad por el correo que embió aquí el Embaxador de Inglaterra -escribía Heredia el 16 de agosto- me proporciona el poder hablar con libertad de nuestra desgraciada espedición y de algunas cosas que tal vez no sabrá V.E.

Acá nos tratan como a los conquistadores de la cosa santa, y dicen que somos verdaderos imitadores de los héroes de las Cruzadas, y de Don Quixote nuestro paisano. A estas voces dió motivo el Príncipe Camilo de Rohan luego que llegó acá, con las noticias de lo que havía visto, y de que nuestros generales havian emprendido el proyecto sin conocimiento del terreno, ni de las disposiciones y fuerzas de los argelinos. No nos era muy dificultoso el disuadir a muchas gentes de juicio que conocen la ligereza del Príncipe de estas impresiones, y yo la havía logrado con algunos, pareciéndome imposible la falta de conocimiento que suponía el Príncipe en nuestros Gefes. Qual pues havrá sido mi sorpresa quando he visto confirmada esta especie en la misma relación que se publica por nuestra corte para su defensa, pues la serie y modo de reconocimientos que se refieren, y una carta de Ricaud de una data de mas 20 años, que es lo único que se produce, hace ver al más ciego que nada sabían del estado actual. $[i]$ Pues que diré del proyecto del desembarco y plan que acompañan de la costa? Es imposible que esos hombres no hayan perdido el juicio quando no ven que un desembarco hecho en un parage en que no havia terreno para poder formarse y obrar la tropa, con un exército a las espaldas, y con una cordillera de montañas al frente de la plaza dominadas unas de otras, es un pensamiento verdaderamente Quixotesco. Para que vea V.E. hasta que punto llega su ceguedad, ha creido G[rimaldi]

13. [Heredia - Roda], París, 10 de febrero de 1776.

114. [Heredia - Roda], París, 30 de junio de 1775. 
que con él podría pillar de nuestro hombre [Aranda] alguna prenda que hacer valer ahí en apoyo de su héroe [O'Reylly], y le embia hecho a la mano el plan de operaciones que ha embiado el Ingeniero Abarca para que le diga su dictumen; pero él se arrepentirá de la tentativa.

Para dibertir un poco este asunto tan melancólico voy a contar a V.E. una anécdota que es regular ignore. Esta Corte ha estado tan sentida del desprecio con que la han tratado en haverse guardado de ella, que si los Ministros no fueran tan moderados, y huviera estado a la frente de ellos Choiseul, huviera havido un escándalo. Llegó el caso de que dió quenta ahí el Ministro al Embaxador de Francia, y le aseguró que las medidas estaban tomadas de tal modo que no podía faltar el golpe. Según mis cómputos pasó esta explicación del 12 al 13 de julio, pues el Embaxador la escribió el 13, y justamente llegó su carta en la misma mañana en que el encargado de los negocios de Londres llenó la corte de la noticia de la derrota, por el correo que le havia llegado la noche antecedente del Embaxador de ahí.

Si esas gentes tuvieran vergüenza para morirse, podría ayudarles la purga que les embió este Ministerio por el correo que llebó la notica del parto de la Condesa de Artois; y se reducía a que Milord Rochfort havía dicho buenamente al Embaxador de Francia en Londres que en el estado en que se hallaban sus cosas con las colonias, el único o el mejor medio que creían poder tomar para reunir los ánimos era declarar la guerra a España y Francia; y que haviéndole objetado entre otras muchas razones, la de que como pensaban poder contrastar las dos naciones, le respondió que sólo tendrían que entenderse con ellos, porque se acababa de ver en Argel el cuidado que podían darles los españoles. Las cartas de Maserano, que llebó el mismo correo, confirman esteramente el riesgo que nos amenaza; y estos Ministros recelan que el aparato y movimiento de los portugueses en nuestras fronteras de América son la manecilla que indica el ánimo de los Ingleses. Esos señores proponen en vista de las últimas noticias que han tenido de América, que esta Corte les saque las castañas del fuego esplicándose con la de Portugal, sobre lo que no se ha tomado aún resolución acá»"1'.

Mientras Madrid se inundaba de sátiras contra Grimaldi y O'Reilly, Heredia iba completando el rompecabezas de lo sucedido en Argel, y de sus consecuencias. Probablemente fue el 17 de septiembre cuando escribió a Roda: «He recibido la de V.E. de 24 de julio con las cartas impresas, de que doi a V.E. gracias. Es regular que mañana nos llegue la nueva relación que ofrece la gaceta de ahi, y me alegraré mucho de que pueda desimpresionar a estos militares del concepto poco ventajoso que han formado de los gefes de nuestra expedición, pues su censura no se limita al de tierra sino que se extiende también al de la marina, y le hacen los cargos con sus mismas cartas impresas. Como ignoro estas materias, y por otra parte conozco la facilidad con que conciben y hablan estas gentes. Suspendo mi juicio hasta ver más claro en el asunto» ${ }^{116}$.

115. [Heredia - Roda], París, 16 de agosto de 1775.

116. [Heredia - Roda], Sin fecha. [17 septiembre 1775]. 


\section{El relevo de Grimaldi}

Ei relevo de Grimaldi en la Secretaría de Estado, si bien no podía considerarse inminente debido al respaldo que le prestaba el propio Carlos III, era particularmente esperado por muchos, y los rumores acerca de sus deseos de retirarse del ministerio circulaban ya desde los primeros meses de $1775^{117}$.

Las tormentosas relaciones de Aranda con «el bello abate» llegaron a un punto sin retorno con motivo de la empresa de Argel ${ }^{118}$, y Aranda llegó a estar convencido de que Roda sería el llamado a ocupar la Secretaría de Estado. El ascenso de Moñino, hasta entonces sólo presumido como una posibilidad más de recambio en el gabinete carolino, representó un gran chasco para los aragoneses de París, sobre todo por no acabar de entender bien del papel que había desempeñado Roda en el trasunto sucesorio, pues, en opinión de Olaechea y Ferrer, Roda «no en todas las ocasiones fue fiel al conde» "19: «He visto -escribía Heredia-en la gaceta, que ha llegado oy, la promoción; y aún que no me ha cogido de nuevo, no he podido evitar una grande rebolución que me ha causado, de la qual no he podido aún recobrarme» ${ }^{120}$.

A finales del mes de diciembre de 1776 escribía Heredia: «He recibido dos cartas de V.E., y he diferido responderlas hasta la ocasión de extraordinario por poderlo hacer con más libertad.

Acá estábamos noticiosos de todos los antecedentes que ahí havían ocurrido, los quales nos persuadian que no podia dejar de suceder el retiro de mi Gefe; y como teníamos bien presentes sus antiguas ideas, lo mismo fue anunciarnos su demisión [sic] que dar por cierto lo que ha sucedido. Lo único que me ha cogido de nuevo es haverme dicho S.E. como cosa cierta que se le havía propuesto a V.E. la Secretaría de Estado con la idea de traher a Moñino a la de Gracia y Justicia, lo que, si es así, parece que indica no haver sido tan dueño de la elección de su sucesor como yo me lo figuraba; bien que por una parte me ocurre que esta misma idea ha podido nacer de él para ocultar mejor su juego, estando asegurado de que no la abrazaría V.E. En todo caso, aunque puede V.E. imaginarse bien que nada nos podía ser más agradable que el que V.E. huviera admitido la Secretaría de Estado, havemos juzgado que ha hecho muy bien en reservarla, y que ha obrado con el conocimiento y juicio que le es tan propio.

117. «Escrive el Abate Pico a Beliardi, que Grimaldi se da por cansado, diciendo querer soltar la carga; pero el mismo Pico da a entender, que no lo crehe. Sea lo que fuere el tiempo nos lo dirá». Aranda Roda, París, 25 febrero de 1775. [Autógrafa].

118. «El propio Aranda tampoco estuvo callado en aquella ocasión. Culpó a Grimaldi del fracaso, y le echó en cara que, una vez más, hubieran prescindido de él como militar. En adelante, Grimaldi y Aranda cortaron su correspondencia confidencial, y si al margen de los despachos oficiales, queria el conde que sus opiniones más íntimas llegaran a oídos del rey, debía valerse para ello del confesor real $P$. Osma, o de su propia esposa, Ana $M^{a}$ del Pilar, que se habia quedado en Madrid sin acompañar a su esposo a la embajada de Paris". OLAECHEA, R. y FERRER BENIMELI, J.A.: El conde..., I, 66.

119. OLAECHEA, R. y FERRER BENIMELI, J.A., El conde de Aranda, I, p. 44.

120. [Heredia - Roda], París, 10 de febrero de 1776. 
Acá es general la combersación sobre los deseos del nuevo Embaxador de obtener la Virreta. Yo no dudo de ellos, y aún le juzgo este nuebo estado casi tan necesario como el antiguo Duque de Lerma. Pero por otra parte me figuro que para preparar el logro de su idea havrá dicho mil veces que no debe fiarse el Ministerio de Roma a un eclesiático; y en este caso, [¿] quién echará el cascabel al gato? [i] El succesor? V.E. lo conoce. No le veo otro medio que el de hacerse proponer por la corte de Roma, que no carece de dificultades» ${ }^{21}$.

En la misma carta se hacía también referencia a otra caída política sonada, la del íntimo colaborador de Carlos III, el marqués de Tanucci: «Rara constitución ha sido la de nuestro Amo en verse forzado a desprenderse de sus dos Ministros faboritos a un mismo tiempo. Puede ser que V.E. lo sepa, pero poco se pierde en que yo lo repita. La desgracia de Tanuci se ha preparado en Viena, y el principal motor ha sido el Barón de Breteuil, Embaxador de Francia, que aora está aquí, hombre hábil y osado, que consubaba aversión contra Tanuci desde su residencia en Nápoles, y que sabía quan agradable havía de ser a esta Corte su desgracia, por lo exasperada que estaba por el asunto de los granos, de que no han podido sacarle un marabedí; y en efecto se ha celebrado mucho en esta Corte su caida» ${ }^{122}$.

El panorama del torbellino creado por la caída de Grimaldi y la elevación de Moñino a la Primera Secretaría tardó en apaciguarse, y ni Aranda ni Heredia ocultaban su preocupación por el rumbo que en adelante tomaría la dirección de la Primera Secretaría: «Su carta de V.E. ha llegado tan a tiempo, que antes de haverla abierto me havía dado a leer S.E. otra en que hablando de los motivos porque no se miraba bien a V.E., refería entre otros la gran protección que havía hallado en V.E. el que se va, lo que nos havía dejado llenos de confusión. Pero todo se nos hizo claro en vista de la de V.E., porque justamente el que escribe es el mismo que dió la noticia de la renuncia o resistencia de V.E. en admitir, de que hablé en otra ocasión; y aunque el tal sugeto no ha entrado jamás en la oficina donde se forja la moneda, la recoge de los que andan en ella, con quienes tiene conexión, y la comunica como éstos se la dan. En todo caso yo compadezco infinito a V.E. pues, aunque conozco bien su modo de pensar y estoi bien persuadido de lo que desea, todo esto no basta para quitar el disgusto de la situación, ni a mí el sentimiento de verlo en ella.

De Moñino sólo havemos sabido que llegó a Génova por las noticias públicas; y por carta de nuestro Cónsul de Marsella, que havía orden para hacerle a su paso los honores de Mariscal de Francia; y haviendo procurado aclarar esta especie por la nobedad de los honores militares a quien no lo es, havemos sabido que de acá se dió la orden para que lo traten como a los Ministros de Estado, que equibale ahí a Consejero, y que los honores que a éstos se hacen acá son los mismos que a los Mariscales. No es poca fortuna para él hallar ahí formada la Junta que le serbirá de escudo con que abroquelarse, y no dudo que piense como quiera en su interior, seguirá la

121. [Heredia - Roda], [s.l.] [s.f./finales de diciembre de 1776 o primeros de enero de 1777].

122. [Heredia - Roda], [s.l.] [s.f./finales de diciembre de 1776 o primeros de enero de 1777]. 
ruta que encontrará trillada, por lo que las cosas seguirán el mismo rumbo que hasta aquí. Lo que me tiene con más curiosidad es ver como se manejará con la oficina de que he hablado arriba, pues suponen que no le es faborable, y si llega a captarla temo que mi [(antiguo tachado)] quondam mayor tendrá un beneficio simple como nuestro Pisón, cuya suerte que antes me lasmimaba [sic, por (lastimaba)] embidio aora» ${ }^{123}$.

Pero Moñino fue generalmente bien acogido y, como el propio Heredia escribía: «Todos combienen en el buen recibimiento del nuevo Ministro, y me alegro mucho de ello, pues puede ser que teniendo proporción trabajará en reunir los ánimos, y como no le falta habilidad puede esperarse que lo consiga» ${ }^{124}$.

\section{La ofensiva contra los colegios mayores}

Roda estaba por entonces enteramente dedicado a la reforma de los colegios mayores. En 1770 se había presentado al rey el Memorial por la libertad de la literatura española redactado por Pérez Bayer ${ }^{125}$, y el 23 de febrero y 3 de marzo de 1771 se dictaron las reales cédulas que abordaban las primeras reformas en profundidad, que venían a significar el control gubernamental de la provisión de las becas, y el golpe definitivo llegó el 21 de febrero de 1777, fecha en la que Carlos III firmaba el decreto de reforma de los seis colegios mayores ${ }^{126}$.

La ofensiva contra los colegios venía a complicarse con la delicada situación política por la que atravesaba el gobierno, puesto que, al mismo tiempo, el asunto del autillo de Olavide, que había sido detenido el 14 de diciembre, se situaba también en el centro de la palestra, y Francia reclamaba una acción más decidida por parte de España ante el conflicto abierto con la guerra de emancipación de las colonias inglesas de Norteamérica.

El 22 de marzo Heredia encontró otra «ocasión segura» para enviar a Roda un largo epistolón, en el que, entre otros muchos asuntos, se hacía referencia expresa a la reforma: «La ocasión que huvo de poder escribir con seguridad nos ha instruido de lo que pasa, y en realidad el teatro presenta una perspectiva bien melancólica para lo benidero.

Tengo por cierto que la probidencia sobre Colegios embrabecerá la tempestad; y sino reflexionara que es V.E. quien lo ha hecho, casi caería en la tentación de pronosticar que no se exequatará, o que será con tal tibieza que en el primer momento faborable bolverán las cosas a su antiguo ser». Por otra parte, algunos de sus corresponsales pintaban una situación bastante comprometida para el propio Ministro de

123. [Heredia - Roda], París, 6 de febrero de 1777.

124. [Heredia - Roda], París, 22 de marzo de 1777.

125. PÉREZ BAYER, Francisco. Por la libertad de la literatura española. Estudio preliminar Antonio MESTRE SANCHIS, Alicante, 1991.

126. SALA BALUST, Luis. Visitas y reforma de los Colegios Mayores de Salamanca en el reinado de Carlos III, Valladolid. 1958. MESTRE, A. Gregorio Mayans y Siscar. Epistolario VI. Mayans y Pérez Bayer, Valencia, 1977, pp. LIX-LXI. 
Gracia y Justicia, pues el 10 de marzo le habían escrito desde Madrid que Roda había presentado su dimisión, que Carlos III estaba furioso por no querer que se fuese y que había habido «algo con este motibo entre Padre e Hijo», pero que, al no tener confirmación del asunto por ninguna otra vía, había considerado «imbentada la especie» ${ }^{127}$.

La reforma de los colegios, y sobre todo la provisión de las plazas que habían quedado vacantes, pasó a ocupar un puesto destacado en la correspondencia entre los dos aragoneses. «He recibido las dos cartas de V.E. de 5 de mayo, y 2 de junio; y con esta última los decretos que V.E. me embía sobre los Colegios, de que doi a V.E. mil gracias, y he entregado un exemplar a S.E. Los he leido con mucho gusto, y me sirbe de grande satisfacción lo que me dice V.E. de ser muchos los opositores que se han presentado. Prueba de ello es que hasta acá bienen a buscar recomendaciones, como puede V.E. verlo por la adjunta esquela que me ha entregado el Tesorero Llobera, y le he ofrecido embiársela a V.E." 128

\section{El autillo de Olavide}

El proceso inquisitorial a Olavide fue, sin lugar a dudas, uno de los asuntos más polémicos del reinado de Carlos III, puesto que para el mundillo ilustrado la nueva ofensiva de la hidra inquisitorial representó la confirmación del vigor del oscurantismo, sorprendentemente consentido por el «melifluo san bernardo» de Carlos III.

«El 14 de noviembre [de 1776] -escribía Defourneaux-, a las seis y media de la tarde, el alguacil mayor de la Inquisición, un grande de España, el Duque de Mora, se presentó en el domicilio que ocupaba Olavide en Madrid, el de Luis de Urbina, y en tanto comenzaban los resgistros, Pablo de Olavide era conducido a la prisión del Santo Oficio. Durante dos años, iba a ser borrado del mundo de los vivos, haciéndose el más absoluto silencio sobre su suerte» ${ }^{129}$.

Parte de la intelligencia española, que había hecho de la exaltación del reformismo borbónico sinónimo de la «modernidad» de España quedó pofundamente desconcertada ante la inesperada noticia ${ }^{130}$.

Desde Roma, José Nicolás de Azara escribía a Roda: «¿Es posible que se vean aún cosas como la que acaban de hacer con Olavide? Yo no soy su amigo, pero la humanidad me hace llorar lágrimas de sangre?» ${ }^{131}$.

En París no terminaban tampoco de dar crédito a las noticias que llegaban de España relacionadas con la prisión del intendente de Sevilla, como evidencia la escasa, pero temerosa, alusión que Heredia hizo en una densa y secretísima carta en la que también se ocupaba del relevo de Grimaldi, de la caída de Tanucci, de la división del

127. [Heredia - Roda], París, 22 de marzo de 1777 y [Heredia - Roda], París, 13 de abril de 1777

128. [Heredia - Roda], París, 21 de junio de 1777.

129. DEFOURNEAUX, M.: Pablo de Olavide el afrancesado. Sevilla, 1990, p. 256.

130. Vida literaria de Don Joaquín Lorenzo Villanueva, Ed. Germán Ramirez Aledón, Alicante, 1996, pp. 119-133.

131. Azara - Roda, Roma, 5 de diciembre de 1776. III, p. 57-58. El espíritu de D. José Nicolás de Azara descubierto en su correspondencia epistolar con Don Manuel de Roda, Madrid, 1846, III, pp. 57-58. 
gabinete y del pueblo francés entre partidarios y no partidarios de lanzarse a una nueva confrontación con Inglaterra, de los encargos literarios de Roda, y de la llegada de Franklin a Francia: «Acá -escribía Heredia- se ha hecho bastante pública la prisión de Olabide, y nos atacan estas gentes con la mayor insolencia. Si llega a publicarse, como es regular, en las gacetas extrangeras, y si es cierto, como lo escriben de Cádiz, que se preparaba alli un auto de fe público, havemos de ser la irrisión de estas gentes, y nos veremos forzados a cerrarnos en casa mientras dure la tempestad» ${ }^{152}$.

El 13 de enero las prevenciones de Heredia se vieron plenamente confirmadas: «Se han verificado, aún mucho más de lo que me imaginé, los temores que expliqué a $V . E$. de la impresión que havia de hacer en este pueblo la prisión de Olabide, y el expectáculo que anunciaban de Cádiz como un auto de fe, que parece se ha reducido a la publicación del edicto con grande pompa y aparato.

Esta mogiganga es la que nos ha arruinado, pues como aquella ciudad está llena de comerciantes franceses, han inundado este reino de relaciones exageradas y equivocadas pintando que se havía restablecido la Inquisición en todo su antiguo vigor, y que hasta el mismo Rey se havía declarado que estaba sugeto a ella. Esto me hace recelar si havrán publicado la Bula de Paulo $4\left[^{\circ}\right]$ " "Cum ex apostolanis officio", como lo dicen muchas cartas, pero que no puedo acabar de creerlo porque no creo que ni la insolecia, ni la debilidad lleguen a tal extremo. Sea lo que sea de ésto, lo que puedo asegurar a V.E. es, que desde que estoi acá no he visto ningun acaecimiento cuya combersación haya durado tanto tiempo y haya sido tan general, como éste. No causará nobedad a V.E. el que nos tengan por más bárbaros que los salbages de Canadá; pero sí lo sorprenderá la desbergüenza con que con este motivo hablan del Confesor y el penitente, diciendo del primero que es un embustero ignorante, $y$ del segundo un imbécil que ha perdido la cabeza; y para acreditarlo corre en el vulgo la historieta de que paseándose los dos al anochecer vió el penitente unas lucérnigas que lo sorprendieron por su brillantez, y que haviendo preguntado al compañero que era aquello, le respondió que las ánimas del Purgatorio que estarían penando hasta que se restableciera la Inquisición, lo que se ofreció exequtar inmediatamente.

El Embaxador de París y el Secretario de Embaxada también andan en la danza sin comerlo ni beberlo, pues se supone que están llamados, según unos para quemarlos, y los más moderados dicen que para ponerlos en prisión; y como no nos creen con deseos de ser asados, dan por sentado que havemos renunciado al serbicio de España y que nos quedamos acá a vivir como particulares. Esta noticia me ha llegado por muchos conductos, y anteayer nos la confirmó el Abate Roxas de oidas a Mr. de Seguier, el abogado general. Sin duda la han fundado sobre lo que se hizo ahi en nuestro tiempo, y sobre la idea general en que están todos de que se ha restablecido el Tribunal en toda su fuerza; $y$ de estos principios deducen, y no mal, que debemos purgar este pecado. V.E. se reirá con razón, como lo hacemos nosotros, de la simple-

132. [Heredia - Roda], [s.l.] [s.f./ finales de diciembre de 1776]. 
$z a$ de estas gentes; pero conocerá igualmente quan sensible debe ser que unas gentes que ignoran absolutamente como piensa el mundo, nos hagan ridículos en toda Europa, justamente por el mismo medio que parece han escogido para hacerse admirar a vista de todas las naciones que concurren en Cádiz.

Hasta aquí tenía escrito quando me han traído la Gaceta de Dospuentes, que entre otras remito a la Secretaría, y he hallado en ella el artículo de que embio a V.E. copia. La última cláusula alude a la especie que también corre aquí, de la idea que debe formarse esta nación de la rama de España para en el caso de faltar la succesión de esta casa real. Me ocurre con este motivo el uso que se acordará bien V.E. hizo en nuestro tiempo la Inquisición de las gacetas, y si huviera proporción se les podría pagar con la misma moneda» ${ }^{133}$.

«Las gacetas -escribía Heredia el 6 de febrero- han continuado en batirnos furiosamente, y por remate se ha publicado en estos días una obra de Marmontel intitulada los Incas, o la destrucción del Imperio del Perú, cuyo objeto es hacer ver los males que han causado el fanatismo y la superstición, y ya puede V.E. suponer que no se olbida en ella la Inquisición. Es una mexcla de historia y de novela, muy al gusto de estas gentes, pero que un hombre de juicio no puede aprobar. Son dos tomos en octavo carísimos, pues los venden sin enquadernar a 18 libras» ${ }^{3.34}$.

A finales de 1778 Heredia retomaba la cuestión Olavide: «La famosa sentencia de Olabide ha hecho olbidar por algunos días a estos monsieures de sus enemigos los ingleses, pues no se ha hablado de otra cosa. Como yo estoi cruxido a estas baquetas me ha hecho poca impresión oirnos tratar de bárbaros y de todos los demás epítetos con que nos faborecen. El Conde de Torreblanca me envió una relación en que decía lo havían amonestado tres veces antes de prenderlo, y que le havian hecho hacer unos exercicios. Esto me ha servido para tapar la boca a quantos me han insultado, pues no pueden dejar de reconocerlo por loco; pero la verdad es que como no he visto confirmada esta noticia en ninguna otra relación, tengo mis dudas sobre ella, y me las aumentan Villahermosa y Ramos que combinándola con lo que ellos vieron ahí la tienen por falsa. Las relaciones que han venido hasta aora son tan diminutas y tan varias en las circunstancias, que no sabemos otra cosa de cierto sino que lo declararon herege, y lo condenaron a destierro de ciertos lugares y a ocho años de reclusión en un combento» ${ }^{135}$.

El 24 de febrero de 1779: «Todavía dura acá, sin que haya cesado un momento, la combersación de la Inquisición y de Olavide. Cada día inventan nuevas historietas para ridiculizarnos. La del día es de que se ha escapado y ha llegado a Perpiñán bestido de fraile y pidiendo limosna por el camino. Lo singular es que ay cartas de Perpiñán que lo dicen; y antes de ayer me aseguraron que el Arzobispo de Tolosa es-

133. [Heredia - Roda], París, 13 de enero de 1777.

134. MARMONTEL, Jean François (1723-1788): Les Incas ou la destruction de l'empire de Pérou, Paris, 1777, 2 vols. [Heredia - Roda], París, 6 de febrero de 1777.

135. [Heredia - Roda], [s.1] [s.d]. [noviembre-diciembre 1778]. 
cribia que estaba en Narbona. Yo he creido que algún Pícaro ha tomado su nombre viendo una ocasión tan buena para estafar, porque Olavide oy en Paris, y en toda Francia sería más cortejado que el Emperador.

Hasta esta ocasión no havía yo comprendido bien de donde nacía el odio con que miran a la Inquisición hasta las personas que más aman la religión en este Reino. El Libro que acompaño a V.E. publicado el año de 1762 por el Abate Morelet, que vive aún, me ha quitado todas las dudas. Como tengo a Aymerico he cotejado todas las citas y las he hallado exactas, aunque no corresponden los lugares a la edición de 1585, que es la que yo tengo, por haverse governado el author por la de 1558 mucho más diminuta, y variada en la forma por el mismo Peña en la posterior de $1585 »^{136}$.

En la útima de las cartas conservadas en el legajillo, la del 11 de abril de 1781, se hacía también referencia al asunto Olavide: «El negocio de Olavide ha salido mucho mejor de lo que yo crehi, pues temi que se traspirara nuestra solicitud y que nos hiciéramos el objeto de las sátiras de las gacetas y de las combersaciones de aquí. Pero veo que nadie lo ha olido, y que estas gentes han guardado un gran secreto, lo que no ha sido poca fortuna. No me pasó jamás por la imaginación que este Ministerio lo entregara, porque los huvieran apedreado; pero tampoco crehi que lo negaran, y tuve por cierto que para evitar el lance le avisarían bajo mano que se fuera, $y$ responderían que quando havían dado la orde estaba fuera de Francia. Ya que no practicaron antes esta diligencia la han exequtado sin duda después, porque pasados algunos días de la respuesta escribieron de Tolosa que se havía ido, y me ha dicho S.E. que estaba en Laussana, en donde debe de vivir muy retirado, pues que no lo he oído a ningún otro» ${ }^{13}$.

\section{LA IMAGEN DE ESPAÑA Y LA CULTURA ESPAÑOLA}

\section{La traducción francesa de Clarke}

La cuestión de la imagen de España trasmitida por la cultura literaria había aparecido de forma inmediata en la correspondencia, pues nada más hacerse cargo de los papeles de la Embajada, Heredia encontró «un montón de exemplares» del «Etat present de l'Espagne et de la nation espagnole. Lettres ecrites à Madrid pendant les Annes 1760 et 1761 par le Dr. Eduard Clarke» ${ }^{138}$, que fueron recogidos por el gobierno francés a instancias del embajador conde de Fuentes.

Desdevises, al servirse, entre otros ejemplos, del caso Clarke para ilustrar el peso negativo que para el desarrollo de las ciencias y el espíritu crítico habían tenido tanto el tribunal de la Inquisición, como el férreo control que ejercían el Consejo de Castilla y el Juez de Imprentas sobre las publicaciones, resaltaba que los motivos que

136. [Heredia - Roda], París, 24 de febrero de 1779.

137. [Heredia - Roda], París, 11 de abril de 1781.

138. CLARKE, Edouard, Etat présent de L'Espagne et de la nation espagnole. Lettres ecrites a Madrid, pendant les annes $1760 \& 1761 / .2$ vols, Bruselas/París, 1770 . 
se aducían para la prohibición de determinadas obras resultaban a veces pueriles: «El Gobierno español, prevenido por la policía francesa, impide durante varios años la puesta a la venta de una traducción francesa de un viaje por España de M. Clarke, capellán de Lord Bristol. La razón es que el rey Carlos III es calificado en ella de "Nemrod de su siglo" y acusado de "haber hecho zapatos". El autor tampoco ha comprendido que "si una parte de las provincias meridionales de España no es tan industriosa como los catalanes, esto se debe tan sólo al calor excesivo del clima". El autor se atrevió a escribir que "todos los imputsos dados por el rey Fernando VI a la industria parecían una lluvia que cae sobre un desierto árido, en el que ni raíces ni semillas podrán nunca prender" ${ }^{139}$.

Sin embargo, las consideraciones acerca de la obra del antiguo capellán de lord George Willian Hervey no siempre respondían a las estrechas miras de algunos censores, pues hombres de la categoría de Roda y Heredía mantenían posiciones ciertamente críticas, pero mucho mejor justificadas, ante la obra de Clarke.

Respecto a la traducción francesa de la obra de Clarke, que Roda no conocía ${ }^{140}$, escribía Heredia: «Los desatinos que ay en ella me han hecho reir mucho, porque no me parece que no los escribió con malicia. El tal Clarke, según me han informado, estubo ahi de Capellán de Milord Bristol, Embaxador de Inglaterra, y se conoce que tubo amistad y comunicación con Mayans y Bayer, pues pone en dicha obra dos cartas que le escribieron esos señores. Si acaso no huviese llegado ahí, con el aviso de V.E. embiaré un exemplar por el primer extraordinario que parta» ${ }^{: 41}$.

El capellán de Lord Bristol había aprovechado su breve estancia en Madrid entre 1760 y 1761 para recopilar las más variadas informaciones sobre el país. Sus Letter concerning the Spanish nation, publicadas en 1762 tras su regreso a Inglaterra constituían «un mero catálogo de información por temas en el que no hay línea narrativa» ${ }^{142}$, porque el capellán Clarke, «a la vez hombre erudito y teólogo anglicano un si no es pedante, no tenía estofa de narrador de viajes», incluía en su obra «largas disquisiciones históricas del marqués de Mondejar y doctas cartas por él recibidas de Mayans sobre la situación literaria de España, y de Pérez Bayer sobre los estudios hebráicos en la Península (...) Se interesa por el gobierno de España, sus tribunales (principalmente por el de la Inquisición, como es obvio), las academias, el teatro y la

139. DESDEVISES DU DEZERT, G. La España del Antiguo Régimen. Red. FUE, Madrid, 1989. Los comentarios los debe sacar de una de la muchas «censuras» escritas contra la obra de Clarke, pues cita, en la nota 69 A.G. Central de Alcalá, Estado, leg. 3.559.

140. Si la obra había, como había, circulado en España, no llegó a manos de Roda, pues, el 3 de diciembre de 1773 escribía Heredia: «Si me huviera llegado ocho dias antes la carta de V.E. tendría ya ahí la obra de Clarke, pues la huviera remitido por el extraodinario que partió por ese tiempo; pero la embiaré por el primero que despachemos. [Heredia - Roda], París, 3 de diciembre de 1773. El 20 de enero de 1774 le comunicaba haberle remitido «la obra de Clarche [sic] que le tenía ofrecida».

141. [Heredia - Roda], París, 1 de octubre de 1773. Sobre las circunstancias de las relaciones con Mayans, PESET, V. Gregori Mayans i la cultura de la Il.lustració. Valencia, 1975, pp. 169-173.

142. GUERRERO, Ana Clara, Viajeros británicos en la España del siglo XVIII, Madrid, 1990, pp. 44. 
literatura (sus listas de autores son un verdadero cajón de sastre), las pinturas y los libros de El Escorial, la agricultura y el arte de las varias regiones que puede visitar: el centro, Andalucia, Valencia y Cataluña; en Madrid casi sólo merecen su atención las instituciones de cultura y los autos religiosos representados en los teatros. Halla en el pueblo español los mismos tópicos, más que rasgos, generalizados por los precedentes viajeros: gravedad, generosidad, inteligencia, sangre fría, belicosidad (cual se vio en la guerra de sucesión), beatería, aferramiento a la tradición, de lo que halla los más pintorescos y significativos ejemplos en la universidad de Salamanca» ${ }^{143}$, de manera que la Critical Review remataba la reseña sobre la obra de Clarke diciendo que había dado a luz un texto «parecido al país que describe, con amplias zonas estériles entremezcladas con algunos lugares agradables» ${ }^{144}$.

William Beckford, viajero por España en los años 1787-88, calificó las observaciones de Clarke de «pesadas», pues, en cierto modo, esta época empezaba a escapar ya de los esquemas del viaje «filosófico» para rozar el «prerromanticismo»o, como parece imponerse, el viaje augustean, que prestaba más atención a los saraos cortesanos de la nobleza ${ }^{145}$.

La relativa ponderación de que Heredia hizo gala respecto al $\mathrm{P}$. Clake se tornaba, en cambio, en ira en el caso de algunos «plumíferos» franceses, especialmente Marmontel, Laporte o Raynal, al menos antes de tener ocasión de conocer personalmente a este último: «Es una lástima -escribía el 3 de diciembre de 1773-la ignorancia y desbergüienza conque nos maltratan estas gentes en sus escritos. Es niño de teta Clarke en comparación de un Mr. La Porte ${ }^{146}$ [sic], author del viajador francés, en que dice de España cosas que, por tan desatinadas, no puede uno menos que reirse al leerlas. [i] Pues el exjesuita, el Abé Raynal en su Historia philosofica de los establecimientos de los Europeos en las dos Indias) ${ }^{147}$ [sic]. Es una insolencia como

143. BATLLORI, «Presencia de España en la Europa del siglo XVIII». Historia de España (Menéndez Pidal), XXXI-I, p.XVI.

144. GUERRERO, Op. Cit. p. 58.

145. GUERRERO, Op. Cit. p. 47.

146. LAPORTE, J (1713-1779), formado con los jesuitas, se separó de la orden en 1742 tras alcanzar un considerable éxito con la publicación de su Pastorale héroique. Buen compilador de obras literarias, es España no gustaron nada las alusiones que hizo en la colección Le voyageur français o connaissance de l'Ancien et de Nouveau Monde (1765-1795), que alcanzó los 42 tomos, de los que Laporte colaboró en los 26 primeros. Desde 1751 a 1778 publicó, en colaboración con Clements, Les Spaectacles de Paris ou calendrier historique et cronologique de tous les théâtres.

147. RAYNAL, Guillaume Thomas François (1713-1796) exjesuita provenzal, autor de la Histoire philosophique et politique des établissements et du commerce des européens dasn les deux Indes, (Amsterdam, 1770, Geneve, 1780-1781, chez Jean-Leonard Pellet). Raynal criticaba apasionadamente a los españoles y a los portugueses, pero también a los franceses. De ahí que la obra fuera prohibida por el Parlamento de París, y Raynal obligado a exilarse. No halló refugio en la corte de Federico de Prusia, y anduvo por la de San Petersburgo, con Catalina II, durante algún tiempo. «Al parigual que la de Buffon -escribe Batllori- la América de Raynal era impúber: como para De Paw, el hombre americano, un ser decrépito, suceptible de ser subyugado y explotado. Esta Histoire sólo pudo publicarse en castellano por Eduardo Luque de Malo en forma reducida (tres tomos, 1784-1789); pero 
nos trata. Yo comí con él, a poco tiempo de llegado a esta Corte en casa del Ministro de Ginevra, y me preguntó muchas cosas alusivas a la expulsión de los Jesuitas de España, proponiendo mil dificultades y dudas sobre lo que yo le decía. Entonces ni sabía yo que havía sido Jesuita, ni havía leido su Historia filosófica; pero si buelvo a encontrarme con él, y me proporciona ocasión, le he de calentar bien las orejas. La tal obra, que ya la tiene ahi el Marqués de Mora, está llena de pasages torpísimos, de odio contra la religión, de un sin número de mentiras, de un furor frenético contra todos los monarcas, y de un fanatismo ridículo; pero, con todo, no se puede negar que ay excelentes reflexiones, y una colección de noticias tan raras que con dificultad se hallarán en ninguna otra obra; por lo que yo la juzgo muy importante para qualquiera Ministro, especialmente en el sistema actual de la Europa en que todas las disputas han de girar sobre aquellos establecimientos.

Uno de los ídolos de Raynal son los chinos, y sabe V.E. que lo han sido igualmente de muchos eruditos franceses, que han delirado con ellos, y aún les han servido para impugnar nuestra religión. Por fortuna el autor [C. de Pauw] de les recherches sur les Americaines ha publicado hace poco les recherches philosophiques sur les Egiptiens et les Chinois, en que hace ver la ilusión con que los misioneros havian deslumbrado a la Europa sobre esta nación, que según sus pruebas, es tan despreciable en su ciencia, artes y costumbres como las demás de la Asia» ${ }^{148}$.

\section{Los plomos de Granada}

Sin embargo, la primera misión que Roda le encomendó relacionada con las actitudes críticas que representaba ahora desde la Secretaría de Gracia y Justicia se relacionaba con un nuevo capítulo del novelón de los Plomos de Granada.

En septiembre de 1773 Roda le encargó que procurase conseguir una «copia de la Censura de la Academia en el asunto de los nuevos descubrimientos de Granada». Heredia, muy ocupado por entonces en los detalles de su nuevo establecimiento, encargó la misión al exsecretario Fernando Magallón, quien se ofreció gustoso a realizar el encargo, aunque el aragonés desconfiase, con motivo, de su diligencia, «porque al carácter de olbidadizo que V.E. le ha conocido, ha añadido el que reina en esta Corte, y lo ocupa todo entero» ${ }^{149}$.

sus doctrinas obstuvieron la mayor difusión a través de la traducción española (Valladolid, 1992) de las Lettres d'une Pérouvienne, de Madame de Graffigny (1747) anteriores a Raynal». BATLLORI, «Presencia de España en la Europa...», pp. XVI-XVII.

148. [Heredia - Roda], París, 3 de diciembre (noviembre tachado) de 1773. PAUW, Conelio: Recherches philosophiques sur les americains ou Mémoires intéresants pour servir à l'Historie de l'Especce Humaine / par Mr. De Pauw, avec una Dissertation sur l'Amerique et les Américains, par Don Pernety, Londres, 1770, 2 vols. Ibíd. Recherches philosophiques sur les egyptiens et les chinois pour servir de suite aux recherches philosophiques sur les américains / par Mr. De Pauw, 2 vols. Londres/Lausana/Ginevra/Berlín, 1774.

149. [Heredia - Roda], París, 1 de octubre de 1773. 
La vieja polémica acerca de los hallazgos en el Sacromonte de Granada ${ }^{(50)}$, lejos de apaciguarse con la condena dictada por Inocencio XI en 1682 se mantuvo latente, y de acuerdo con la feliz expresión de Caro Baroja, de nuevo «la herida, no curada, se infectó en el siglo XVIIl», está vez por obra de los pintorescos Juan de Flores, maestro de Filosofía en Granada y Académico de Buenas Letras de Barcelona y Sevilla, quien llevó a cabo una nueva campaña de excavaciones y descubrimientos en la Alcazaba desde $1754^{151}$, y de Cristobal Medina Conde (1726-1793), canónigo de la catedral de Málaga ${ }^{152}$.

Fernando Magallón era el covachuelista que había desempeñado el cargo de Secretario de la Embajada con el conde de Fuentes y, a pesar del nombramiento de $\mathrm{He}$ redia, recibió orden de Grimaldi de permanecer en París, donde estuvo hasta agosto de 1774. Oficialmente su permanencia se explicaba por haber sido el encargado de los detalles de la negociación para la delimitación de fronteras hispano-francesas que todavía estaba pendiente de concluir, pero, según interpretaciones menos bien intencionadas, para que actuase de espía para Grimaldi acerca la actuación del conde de Aranda, según pensaba el embajador danés Saint Saphrorin ${ }^{153}$. Fuera como fuese, las relaciones personales entre Magallón y Heredia fueron buenas, y motivo de comentarios entre los corresponsales, puesto que también Roda parecía conocer bien el carácter despistado del ahora comisionado ${ }^{154}$.

Mientras en España se avivaba la polémica acerca de la autenticidad de los nuevos descubrimientos de la Alcazaba, tanto Medina Conde, autor del Fingido Dextro, como Pérez Bayer recurrieron en defensa de sus respectivas posiciones a la Academia de Incripciones francesa. Roda insistió en diferentes ocasiones a Heredia para que, de exisitir, consiguiera el informe de la Academia, aunque a decir verdad con escaso éxito ${ }^{155}$.

Heredia iba teniendo conocimiento del asunto no sólo por las cartas de Roda, sino también por otro de sus corresponsales, que, ya en el verano de 1774, le había escrito informándole que se había «empezado a descubrir las falsedades de los documentos de Granada; pero ni me decía el origen de la pesquisa, ni las particularidades del descubrimiento; por lo que he leído todo esto con mucho gusto en la carta de V.E., admirando al mismo tiempo lo basto de la empresa y la temeridad de sus authores.

150. GODOY ALCÁNTARA, Historia crítica de los falsos cronicones, Madrid, 1864, que estudia fundamentalmente el proceso desde los descubrimientos de la Torre Turpiana en 1588 hasta la condena por Inocencio XI en 1682. Especialmente, cap. VIII, pp. 305-333. Red. Facsímil, Madrid, 1981; Granada, 1999; HAGERTY, M.J. Los libros plúmbeos del Sacromonte, Madrid, 1980.

151. AGUILAR PIÑAL, F. Bibliografía, III, pp. 493-494.

152. CARO BAROJA, J. Las falsificaciones en la historia (en relación con la de España), Madrid, 1991, pp. 115-158.

153. OLAECHEA Y FERRER, El conde de Aranda, I, p. 47.

154. «Magallón está tal que puede desafiar a los más finos parisienses, porque el carácter distraído que naturalmente tiene vale aquí una India, y él ha procurado perfeccionarlo» [Heredia - Roda], París, 14 de se[p]tiembre de 1773 .

155. El 3 de diciembre le advertía Heredia que no dejaba a Magallón «de la mano sobre la consabida censura de la Academia, y cree que la tendremos» [Heredia - Roda], París, 3 de diciembre de 1773. 
Muchas veces he recordado a Magallón la especie de la censura de la Academia, pero siempre sin fruto. Aora se ha acalorado mucho y me ha hecho grandes ofertas para quando bolvamos a París. Quando se le coge de manos a boca tiene una actividad extraordinaria, pero en mediando 24 horas todo voló. Veré si puedo cogerlo en uno de sus momentos faborables, y quando no procuraré aberiguar si está en París Mr. Clement, y me entenderé con él») ${ }^{156}$.

Heredia regresó a París a finales de agosto, una vez agotadas las jornadas estivales en Marly y Compiegne, y la cuestión de Granada volvió a recuperar protagonismo: «Recibí la de V.E. al día siguiente que remití a V.E. las copias de las cartas de Medina Conde al padre Tassin y las respuestas de éste al mismo, y a Don Francisco Vayer. En consecuencia de lo que en ella dixe a V.E. fuí a ver la semana pasada al padre Tassin con quien, $y$ [con] el padre [François] Clement, editor del Arte de verificar las datas, estube más de una hora y media, y los instruí de todas las patrañas que se iban descubriendo en Granada, leyéndoles los artículos de las cartas de V.E. en que habla de este asunto. Quedaron muy contentos de saber las particularidades y la felicidad con que se van justificando los embustes, y me dixeron que debía publicarse la noticia en los papeles periódicos para que se hiciera general en toda la Europa, a lo que les respondí que la cosa no estaba aún en ese estado, y que me persuadía que cuidaría nuestra Corte de publicarla a su tiempo. Me confirmó el padre Tassin lo que ya dixe en mi anterior, de que no havía havido acuerdo ni deliberación formal en la Academia sobre este asunto» ${ }^{157}$.

En la correspondencia conservada de Heredia no aparecen más alusiones a los falsarios hasta el 19 de julio de 1777: «En este correo he recibido carta de Martínez, el Alcalde del Crimen de Granada, en que me dice que está trabajando Burgos la relación del proceso de los falsarios, y que cree que la acabará dentro de un mes. Supongo que V.E. querrá que se haga correr acá la noticia, y para esto será preciso que por un extraordinario me embie V.E. abundancia de exemplares, pues cuento embiarlos a los principales diaristas, por cuyo conducto se esparcirá luego la noticia por todas partes» ${ }^{158}$.

Las polémicas y críticas eruditas, en las que, como es bien sabido, tuvo participación fundamental Pérez Bayer ${ }^{159}$, culminaron en un sonado proceso, abierto en

156. [Heredia - Roda], Compiegne, 15 de agosto de 1774. El benedictino P. François Clement (17141793) fue encargado, junto con el P. Biral, por su congregación de continuar el Recueil des Historiens de France... Colaborador también en la Hisoire litteraire de la France..., revisó y reimprimió la tercera edición del Art de verifier les dates, de Clemencet, que conoció múltiples ediciones. Entre sus manuscritos se conserva la obra $L$ 'Art de verifier les dates avant de Jésus-Christ.

157. [Heredia - Roda], París, 30 de se[p]tiembre de 1774.

158. [Heredia - Roda], París, 19 de julio de 1777.

159. «Historia secreta y Diario de lo sucedido en las conferencias que de orden del R. P. Fr. Joaquin de Osma, tuvo en esta ciudad de Toledo desde el día 11 hasta el 24 de abril de 1765 el Sr. D. Christoval de Medina Conde Herrera...con D. Francisco Pérez Bayer, acerca de la legitimidad y suplantación de los nuevos monumentos descubiertos en la Alcazaba de la ciudad de Granada y sus inmediaciones desde el año de 1754 hasta el de 1764. Escrita por el mismo Francisco Pérez Bayer para su gobierno 
1774, y en el que, según Godoy Alcántara, la «Secretaría de Gracia y Justicia previno al presidente de la Chancillería "que deseaba su majestad que se arrancase de raiz la oficina de semejantes ficciones, tan contrarias a la fe pública y perjudiciales al Estado" " ${ }^{160}$, y del que Medina Conde salió finalmente condenado a cuatro años de reclusión en un convento, con prohibición expresa de escribir sobre la materia, aunque se sirvió en adelante del nombre de su sobrino, Cecilio García de la Leña, para defender sus posiciones ${ }^{161}$.

A pesar de la perviviencia de la campaña de los Diaristas contra el antiespañolismo de Mayans ${ }^{162}$, la polémica sobre las aportaciones de la cultura española no alcanzaría cotas de verdadera paranoia gubernamental hasta la aparición del famoso artículo de Masson de Morvillers ¿Qué es lo que se debe a España?, que fue publicado en 1783, un año después de la muerte de Roda, aunque Heredia vivió el proceso con toda

y provado uso y para mayor calificación de la verdad [1764], 19 fols. Igualmente Apuntamientos acerca de las nuevas excavaciones de la Alcazaba...» Mss. Apud. AGUILAR PIÑAL, 2457, 245859. De conflictis Granatensibus Monumentis anno MDCCLV. Ac deinceps detectis atque in lucem prolatis sunopsis Historica. Matriti. Apud Viduam et Heredes D. Joachino Ibarra, MDCCLXXXIX [1789], 38 pp. Apud AGUILAR PIÑAL, 2498. VEGUE Y GOLDONI, A. «Para la historia de la Arqueología en España. El canónigo Pérez Bayer y los nuevos monumentos de Granada». Homenaje a... Mélida, II, Madrid, 1934, pp. 369-382. Idem. 2512. MESTRE, Antonio. Ilustración y reforma de la Iglesia. Pensamiento político religioso de Don Gregorio Mayáns y Siscar (1699-1781), Valencia, 1968, pp. 197-206. El 26 de septiembre de 1780 escribía a Gregorio Mayans que se había entretenido en la revisión de los apuntamientos que hizo en 1765 contra los falsarios de Granada, pues estaba a punto de publicarse la sententencia condenatoria y añadía «A la verdad que es justo se vindique el honor de la nación y no nos tengan los extrangeros por más bárbaros de lo que somos, fuera de que, amigo, mi assunto me ha hecho descubrir en muchíssimos de ellos una gran superficialidad aun en aquello de que se tienen por maestros...». La correspondencia Mayans - Pérez Bayer en Gregorio Mayans y Siscar, Epistolario VI Mayans y Pérez Bayer VI, Valencia, 1977, cit. p. 404-405.

160. GODOY ALCÁNTARA, Op. Cit. p. 325.

161. Razón del juicio seguido en la Ciudad de Granada ante los ilustrisimos Señores Don Manuel Doz, Presidente de su Real Chancilleria, D. Pedro Antonio Barroeta y Ángel, Arzobispo que fue de esta diócesis; y Don Antonio Jorge Galban, actual sucesor en la Mitra, todos del Consejo de S.M.; contra varios falsificadores de escrituras públicas, monumentos sagrados, y profanos, caracteres, tradiciones, reliquias y libros de supuesta antigüedad. Madrid, 1781. Ibíd. AGUILAR PIÑAL, F., nº 4395 y 4397.

162. Heredia y Mayans se conocían personalmente de la época en que Aranda fue Capitán General en Valencia y mantuvieron correspondencia en distintas ocasiones. Cómo no podía ser menos, la polémica suscitada por la Gramática de Mayans, y las turbias maniobras de sus contrarios, que falsificaron solicitudes dirigidas a todas las Academias europeas para que dictaminaran sobre la obra mayansiana, aparece también reflejada en esta correspondencia. En la posdata de una carta del 10 de mayo de 1777 comentaba: «Al tiempo que acabo de escribir ésta me trahe un español llamado Izquierdo, la carta, de que incluyo copia, dirigida a la Academia de Pintura de esta villa, que le ha entregado uno de sus miembros para que tradugera en francés el papel impreso que la acompaña. Como Izquierdo no estaba en los antecedentes no comprendía qué era ésto; pero lo he desengañado de que era una burla de los enemigos de Mayans, y que dijera al académico que no merecía aprecio. Es regular que hayan hecho lo mismo con las demás Academias de acá» [Heredia - Roda], París, 10 de mayo de 1777. MESTRE; A. Historia, fueros y actitudes políticas, Valencia, 1972, pp. 430-431. Ibídem. Epistolario Mayans con Manuel de Roda y Conde de Aranda, Valencia, 1990, pp. 307 y ss., 363 y ss. 
intensidad, facilitando al apologeta Cavanilles el contacto con Juan Antonio Mayans, quien le suministró algunos materiales para redactar la apresurada impugnación de Masson que publicó el valenciano en $1784^{163}$. Pero otros defensores de honor patrio proliferaron con diversa fortuna y, en algunos casos, en forma de empresa mercantil.

Proyectos periodísticos

No habían trascurrido todavía cuatro meses de su llegada a París, y cuando todavía estaba fresca su indignación con Laporte y Raynal, Heredia le daba noticia acerca del proyecto que le había hecho llegar para publicar un «Diario de las bellas artes, y de las ciencias, en que, como verá V.E. ofrece el autor tratar particularmente del estado que tienen en España. Yo pienso verlo y ofrecerle los libros españoles que he traído, y los demás auxilios que pendan de mí, para ver si por este medio se puede desimpresionar a estas gentes de la falsa idea que tienen de nuestras cosas. El verdadero modo de taparles la boca sería haciendo una historia apologética del estado actual de España, y hacerla traducir e imprimir acá en francés. Assí lo han hecho los rusos, contra quienes no se atreben ya a chistar» ${ }^{164}$.

En este caso, Heredia se anunciaba partidario de un proyecto similar al que años más tarde impulsaría Floridablanca, del que saldría premiado Juan Pablo Forner. Sin embargo, no parece que la idea de Heredia fuese la de contratacar con obras al estilo de las de Cavanilles o Forner, sino que se presume más cercano a la elaborada luego por Sempere y Guarinos, aunque ampliando el panorama a los progresos económicos, técnicos, de las artes, la literatura, las ciencias...

A falta de una verdadera obra apolegética, Heredia pudo quitarse alguna espina de encima presumiendo con la edición de Salustio del Infante Don Gabriel, cuya alma había sido Pérez Bayer y que, en general, fue bien acogida por los bibliófilos europeos. Heredia le mostró un ejemplar al librero e impresor Boudet quien, según le contaba a Roda, se «quedó pasmado y prorrumpió diciendo: Aora comprendo lo que antes me causava admiración, de que los libreros de Madrid me encargan que les embie las mejores ediciones de los libros que me piden, y veo que tiene razón a vista de esta obra; y continuando con el mismo estusiasmo añadió: no la havía visto Milord But quando en el mes pasado me decía en Londres que los españoles no hacían cosa de probecho, seguramente que quedrá bien sorprendido quando la vea. La examinó con todo cuidado, y a sangre fria me dixo estuviera cierto de que en punto a impresión ni en Francia ni en Inglaterra no se havía hecho cosa tan buena; pero que en lo grabado hallaba algunos defectos principalmente en el diseño.

Yo me alegré infinito de oirlo porque creo que es el primer elogio que he oido a un francés de España. Puede V.E. decirlo al Sr. Vayer que no dudo lo celebrará igualmente.... ${ }^{165}$.

163. Al respecto, OLAECHEA. «Ignacio de Heredia y su biblioteca», pp. 246-249.

164. [Heredia - Roda], París, 3 de diciembre de 1773.

165. [Heredia - Roda], París, 20 de enero de 1774. El 10 de mayo de 1777 rogaba a Roda le hiciese de intermediario con Bayer: «Sírbase V.E. de hacer entregar esa carta a Bayer que supongo se halla ya 
No todos los intentos de contrarrestar la imagen de los españoles gozaron de la aprobación de Heredia. En una carta fechada el 7 de enero de 1774 aludía a la aparición en el Mercure de France del «Prospectus de una obra periódica intitulada la España literaria. Luego que se publicó me lo traxo un hombre que hablaba bien español y que dixo era su author. Yo crehi ver el cielo abierto, y después de haverlo leido a su presencia, le dixe que havía pensado ir a ver al autor del otro proyecto, que remití a V.E., y ofrecerle mis libros y auxilio; pero que una vez que él destinaba únicamente su obra para la España lo consideraba más acrehedor y podía contar conmigo. Considere aora V.E. mi chasco al saber que, haviendo sacado su pribilegio para asegurarme de la solidez con que procedia, me encuentro en la primera linea a nuestro muy amado el Conde de Cardona [por Moncada, es decir D. José Torres] ${ }^{166}$. Sin pasar adelante le pregunté si era él, y me respondió que sí. Por lo que le pregunté entonces, y dos veces más que ha benido a saber alguna noticia de España, he sacado en limpio que ni tiene libros ni idea ninguna de España, y que el author del otro Proyecto [Diario de las Bellas Artes...] que embié a V.E. ni sabe español ni ha visto otro libro que el que últimamente publicó Ulloa sobre cosas de Indias, que se lo regaló un estrangero amigo suyo que lo havia trahído de Madrid. ${ }^{167}$

Estos son golpes proprísimos del carácter de estas gentes» ${ }^{168}$.

El proyecto de L'Espagne Littéraire nació de la mano del pretendido conde de Moncada como un periódico de carácter bimensual, pero tuvo una corta vida, pues dejó de imprimirse en 1776. Su propósito declarado era desarrollarse como «un véritable cours de litterature espagnole et portuguaise», y en su primer número se hizo

ahí. En ella le aviso que el correo lleba el Salustio que acaba de publicar el primer Presidente del Parlamento de Dijon para el Sr. Infante Don Gabriel a quien lo regala. Si V.E. quiere esta obra podrá abisármelo» [Heredia - Roda], París, 10 de mayo de 1777. Efectivamente, Roda lo solicitó, pero no pudo remitírselo en balote que, apenas unos días antes de recibir la carta de Roda, había enviado por Ruán: "Quando he recibido la de V.E. en que me pide el Salustio del Presidente Brosses havian partido ya los libros para Ruân, y lo embiaré en otra ocasión.

Don Francisco Bayer no me ha escrito, al menos no he recibido su carta; y puede V.E. decirle que he sabido en estos días dejó el Presidente concluida la obra latina del mismo Salustio, y que se está imprimiendo». [Heredia - Roda], París, 21 de junio de 1777.

166. «El Conde de Moncada, a quien yo llamé por equivocación de Cardona, es el mismo Don Joseph de Torres que V.E. ha conocido». Ibíd. 20 de febrero de 1774. D. José de la Torre había sido el impulsor de las Memorias para la historia de las Ciencias y las Artes, que se empezaron a imprimir [el] año 1701. En Trevoux. Traducidas en castellano por D. Joseph de la Torre. Madrid, Juan de Zúñiga, 1742. AGUILAR PIÑAL, F. La prensa española en el sigo XVIII. Diarios, revistas y pronósticos. En Cuadernos Bibliográficos, XXXV, Madrid, 1978, p. 19.

167. ULLOA, Antonio. (1716-1795) Noticias americanas: entretenimientos físico-históricos sobre la América Meridional, y la Septentrional, Oriental. Comparación general de los territorios, climas, producciones, en las tres especies, vegetales, animales y minerales, con reación particular de las petrificaciones de cuerpos marinos; de los Indios naturales de aquellos países; sus costumbres y usos: de las antigïedades: Dircuso sobre la lengua, y sobre el modo con que pararon sus primeros pobladores, Madrid, 1772, F.M. de Mena.

168. [Heredia - Roda], París, 7 de enero de 1774. 
una especie de presentación de «la culture espagnole dans touts les domaines, mais ne poursuit para une longue traduction de les "Cartas Españolas" de Pedro de Arévalo, destinée à presenter l'Espagne au lecteur» ${ }^{169}$

Con la oportunidad que le brindó el desapacho de un correo extraordinario la primera semana de enero de 1774 remitió a Roda la primera muestra de La España literaria, «en la que verá V.E. un Don Pedro Pérez de Arévalo, célebre literato espa$\tilde{n}$ ol, que tengo por cierto que no ha tenido otro padre que al Conde de Cardona, sin embargo de que me ha dicho que vive aún retirado en un lugarcillo cerca de Madrid, que crehe se llama Torrejón.

Casi la mayor parte de lo que hace decir a Arévalo se lo havía dicho yo en las dos o tres veces que ha estado conmigo; y para que pueda tener materia para algunos meses le he ofrecido que le prestaría el viage de Ponz ${ }^{170}$ con conocimiento de que me expongo a no recobralo más» ${ }^{171}$.

Heredia siguió de cerca los pasos del periodista, y el 18 de febrero informaba a Roda que: «El Conde de Moncada, a quien yo llamé por equivocación de Cardona, es el mismo Don Joseph de Torres que V.E. ha conocido. Después de la última aventura que tramó ahí, se fue a Berlín en donde estubo algunos años, y bolvió acá con varias comisiones del rey de Prusia, según dice él, y con el grado de Coronel de sus exércitos, cuyo título ha tenido la misma suerte que las comisiones, las quales se desgraciaron por las intrigas comunes en todas las cortes, y especialmente por la mezquindad del rey de Prusia. Este es su lenguage. Por lo que toca al condado de Moncada, aunque yo no le he preguntado directamente su origen, me lo dió a entender en días pasados, pues hablando de un abogado [Linguet] (que en el día es el objeto de las combersaciones de este pueblo, y de que hablaré a V.E. después) y díchome que havía sido dicho abogado ayudante del Príncipe de Bobo [Beaubeau] en Portugal, viendo la estrañeza que me causaba la transformación de un soldado en un abogado famoso, ocurrió a mi admiración diciendo, acá son muy comunes estas mudanzas, oy verá usted un médico y mañana lo hallará Conde; y para que no me quedara duda en la aplicación me añadió, que haviendo escrito una carta al Sr. Nava desde Alemania en que le refería varias cosas muy ridículas que havía notado en aquel país, y entre ellas la facilidad de titularse, en prueba de ello le dixo que al que havia conocido Don Joseph de Torres lo vería firmado Conde de Moncada.

También me ha dicho que se mantenía de una rentita viagera que se havia fundado en el tiempo de su prosperidad, pero yo creo que no le ha quedado más fondo que el de su industria y el del Diario Literario, de que hablaré a V.E. quando haya ocasión de embiarle los tomos que hayan salido hasta entonces» ${ }^{172}$.

169. SGARD, Jean (dir) Dictionnaire des Joumeaux, 1600-1789, Paris, 1991, 2 vols. I, pp. 384-385.

170. PONZ, Antonio (1725-1792) [Secretario de la Academia de San Fernando] Viage de España en que se da noticia de las cosas más apreciables y dignas de saberse que hay en ella..., Madrid, 1772-1784, por Ibarra.

171. [Heredia - Roda], París, 20 de enero de 1774.

172. [Herediá - Roda], París, 18 de febrero de 1774. 
Efectivamente, el 1 de marzo anunciaba a Roda haberle remitido los números 2 y 3 del Diario Literario, junto con las memorias de Linguet y Carón de Beaumarchais, aprovechando el viaje que desde París hizo a Madrid un ayudante de guardias valonas llamado Colomer ${ }^{173}$. El día 11 del mismo mes de marzo informaba de la aparición de un nuevo número de la obra: «Ayer salió el número 4 del Diario de España en que se dice en una nota que se han visto los authores llenos de cartas que piden se les de a conocer el Pensador, y ofrecen executarlo, pero dudo que puedan cumplirlo porque no creo se halle acá. Son tres o quatro los que trabajan en esta obra y sólo entiende el español Torres. Él les da sueltas las especies o apuntamientos en la francesa, y los otros las ordenan y las bordan a la marabilla, de modo que si Torres tuviera cabeza la obra pudiera ser buena; pero este confunde y equivoca lo que lee y lo que oye como lo verá V.E. en los dos números que he enbiado. El disparate que dice de que el Govierno encargó a Pons el combatir al Padre Caimo ${ }^{174}$ fue efecto de haverle dicho yo que le havía dado la comisión de reconocer las pinturas de los colegios de los ex-jesuitas. Lo recombine después y me ofreció que lo enmendaría, pero lo que hizo fue añadir esta segunda circunstancia, y no hablar palabra de la primera. La famosa historia que trahe en el segundo del secretario Marqués la forjó sobre haverme oido que en España havía una ley que castigaba al criado que se casaba con la hija o parienta que tenía en casa su señor no consintiéndolo éste. Dice que sin estas nobelas y otras bagatelas de este tenor no despacharían su Diario, porque es preciso dar este pábulo a las damas que son las que dan el tono y el crédito a las obras periódicas. Por Iriarte remito a V.E. el número 4 en que se habla de su tío» ${ }^{175}$.

\section{La Historia de América de Robertson}

A Heredia tampoco le pasó desapercibida la publicación en Inglaterra de la polémica obra del obispo escocés William Robertson: «El otro día me dixo el Abate Rainal que el inglés Rober $[\mathrm{t}]$ son havía empezado a imprimir su historia de la América, y que a medida que se impriman los pliegos en inglés los embiaba acá al traductor francés, de modo que se publicaría en los dos idiomas casi a un mismo tiempo» ${ }^{176}$.

La obra de Robertson constituía, junto con las del propio Raynal y las Cornelio De Paw, la quintaesencia del determinismo climático defendido por Montesquieu, pero desde el punto de vista político el aspecto más delicado eran las posturas críticas adoptadas respecto a los procesos de la colonización por parte de los estados europeos, «de la Iglesia evangelizadora y, en especial, de la actuación de los jesuitas» ${ }^{17}$.

17.3. Colomer salió de París el 9 de marzo, y Heredia calculaba que tardaría unos 20 días en llegar a Madrid. |Heredia - Roda], París, 11 de marzo de 1774. El 20 de abril acusaba Heredia recibo de la carta de Roda en que le comunicaba haber recibido los papeles que le envió con Colomer.

174. El viaje del P. Norberto Caimo en GARCÍA MERCADAL, Viajes de extranjeros por España y Portugal, Madrid, 1962, Vol. III.: «Viaje de España hecho en el año 1755».

175. [Heredia - Rodal, París, 11 de marzo de 1774.

176. [Heredia - Roda], [s.1.] [s.f./ finales de diciembre de 1776, primeros de enero de 1777].

177. BATLLORI. «Presencia de España en la Europa...», p. XVII-XVIII. Acerca de la prohibición de la obra de Raynal por el Parlamento de París en 1781, por sus proposiciones impías y ánimo de disolu- 
La polémica que se suscitó en España en torno a la obra de Robertson se sitúa en el escenario del enfrentamiento no siempre larvado entre Pérez Bayer y sus acólitos del grupo valenciano contra la facción más cercana a Campomanes, Presidente de la Academia de la Historia, y resulta bien conocida en sus líneas generales ${ }^{178}$ La propia Gaceta de Madrid publicaba mediado el mes de septiembre una extensa y elogiosísima reseña acerca de la aparición en Inglaterra de la Historia de América del rector de la Universidad de Edimburgo, y el anuncio de haber la Real Academia de la Historia no sólo encargado su traducción a uno de sus miembros, sino de haber nombrado al cronista escocés Académico correspondiente, «en señal de aprecio por la predilección y desvelos que este sabio ha acreditado merecerle el estudio de la historia de aquella nación, y en recompensa de quan benemérito se ha hecho de ella contribuyendo tanto a ilustrarla y derramar su conocimiento en los países extrangeros con las historias de Carlos V y la presente; esto es de dos épocas antiguas de los más gloriosas, memorables y fecundas en sucesos extraordianrios de los anales Españales».

Pero por entonces, la obra estaba incompleta, pues faltaba por aparecer «otra parte, en que se tratará de las colonias Inglesas, de los establecimientos Portugueses en las Indias Occidentales y de los de otras naciones Europeas en las Islas de las mismas, cuyo trabajo va ya mui adelantado» ${ }^{179}$.

Poco antes, en junio de ese mismo año, llegaba también la obra en inglés a manos de Heredia, e informaba a Roda que era «regular que se publique luego en francés» ${ }^{180}$.

Tras un largo vacío en la correspondencia, y mientras la diplomacia francesa procuraba uncir a España con Francia en su guerra contra Inglaterra, escribía Heredia el 4 de agosto de 1778: «Como el sistema actual de nuestra Corte es de huir el cuerpo a ésta, no van ni vienen correos como antes, y por ese motivo no he acusado hasta aquí el recibo de la de V.E. de 15 de junio. Ahora despacha S.E. un correo con motivo del combate naval que tuvieron las dos esquadras francesa e inglesa el 27 de julio, (...) He comprado ya a Robertson, pero no se quando havrá ocasión de poder embiarlos ${ }^{1 \$ 1}$.

ción de la religión y de los fundamentos del Estado, vid. «Discurso pronunciado en el Parlanerito de Paris por Monsieur Antonio Luis Seguier, Fiscal de S.M. Chistianisima, contra la obra intitulada Historia Filosófica. (...) Traducido del francés al castellano por el R.P. Fr. Gabriel de Homar, Agustino». Semanario Erudito, Madrid (1789), XXIL, pp. 3-22.

178. NAVA RODRÍGUEZ, Ma Teresa. «Juan Bautista Muñoz y la Academia de la Historia». B.R.A.H. Madrid, (1990) CLXXXVII, Sep-Dic. 1990, pp. 435-455. Estudio introductorio de MESTRE, A. Gregorio Mayans y Siscar. Epistolario VI. Mayans y Pérez Bayer, y especialmente «Juan Bautista Muñoz. Cronista de Indias» en Historia del Nuevo Mundo de Juan Bautista Muñoz, Valencia, 1990. Una reciente síntesis de la bibliografía acerca de Muñoz en BAS MARTÍN, N. «Juan Bautista Muñoz (1745-1799) y la restauración humanístico-filosófica en la España del siglo XVIII》 Estudis, 24, Valencia (1998), pp. 355-390. ESPONERA CERDÁN, Alfonso. «El alicantino Antonio de los Reyes (OFM) y su dictamen sobre la Historia de W. Roberson (1778)». Estudis, 23, Valencia (1989), pp. 297-320.

179. Gaceta de Madrid, 16-09-1777.

180. [Heredia - Roda], París, 21 de junio de 1777.

181. [Heredia - Roda], París, 4 de agosto de 1778. 
Mientras tanto, en abril de 1778 la Real Academia había emitido su dictamen favorable sobre la traducción de la obra del historiador escocés, que había sido encomendada a Ramón Guevara Vasconcelos, pero la pugna entre el grupo de Pérez Bayer y Vicente Blasco con Campomanes y sus académicos, determinó que con el apoyo de Gálvez primero, y del propio Floridablanca más tarde, se prohibiese, en el contexto de la nueva guerra contra Inglaterra, la circulación de la obra de Robertson en todos los dominios de la Corona, y que se encomendase la tareá de lavar el honor patrio a Juan Bautista Muñoz. Campomanes y la Academia quedaron desairados ante la decisión por «vía reservada» de preparar una Historia del Nuevo Mundo que sirviera de réplica a la obra de Robertson y rescatase la historia de América de manos de los extranjeros, pero su gran proyecto no daría un modesto fruto editorial hasta 1793.

En la correspondencia de Heredia el asunto volvió a aflorar de nuevo en febrero del año siguiente $y$, pese a la longitud del texto, resulta interesante su reproducción, no sólo en cuanto el propio Heredia había tomado sobre sí la tarea de hacer algunas observaciones a la obra, con el desinterés y desprendimiento que Olaechea supo captar al trazar su perfil psicológico, sino porque constituye un testimonio importante de su actitud ante el problema de la proyección de la imagen de España:

«Por el último correo me avisan el que acaba de recivir sobre la traducción de la historia de Robertson, y que el Ministro de Indias [Gálvez] havía encargado la impuganación de esta obra. Me alegraré mucho de que este encargo esté en manos de algún sugeto de juicio que sepa tratar a Robertson con la atención que merecen su crédito literario y su carácter personal; y que por otra parte tenga la instrucción y discernimiento necesarios para no empeñarse en la defensa de cosas que se ven oy con otras luces que en lo pasado.

Quando lei esta obra noté algunas faltas de exactitud en hechos que refería sobre la fé de nuestros authores. Se lo hice ver a Huerta ${ }^{182}$ que venía de Inglaterra con grande idea de Robertson, y me instó mucho para que hiciera el examen de la obra, y le remitiera al autor los reparos que hallara, asegurándome de su docilidad y agradecimiento. Poco después llegaron acá dos españoles que venían de Inglaterra, y havian visitado a Robertson en Edimburgo, los quales me dijeron mil bienes de su carácter, de su afición a los españoles, y de los deseos que les havía explicado de que le advirtieran los hierros que huviera cometido en su historia para enmendarlos. Esto me decidió a dedicarme al examen ciñéndome únicamente a las faltas de exactitud en las citas, con ánimo de enviarle lo que huviera notado. He trabajado en ello algunas temporadas, porque es tarea muy molesta y fastidiosa, y tengo notados bastantes pasages nacidos, unos de equivocación, otros de falta de inteligencia de nuestra lengua, y algunos pocos de un poquito de malignidad. Voy a continuar el examen, y si $V$.E. cree que el sugeto encargado ahí de la impugnación es capaz de desempeñarla con honor de la nación, le remitiré a V.E. mi trabajo para que pueda comunicárselo.

182. Se refiere al filólogo y humanista José López de la Huerta (1743-1809), conocido por su obra lexicográfica sobre los sinónimos en la lengua castellana, que ejercía entonces como Oficial de la Secretaría de la Embajada en Londres desde 1774, y sería trasladado a la de París en 1777, antes de ser destinado a Viena. 
No puedo dexar de reirme de la extravagancia humana al ver la suerte de esta historia. Los ingleses han hecho poco aprecio de ella porque en el estilo ha imitado a los franceses, y porque a nosotros nos ha hecho menos malos de lo que ellos nos creen. Acá y en la mayor parte de Europa nos ha hecho un grande bien porque creiéndola verdadera han formado de nosotros mejor concepto del que tenían; y en España se prohive como denigrativa a la nación. Dado ya el paso es conveniente justificarlo lo mejor que se pueda, porque de otro modo confirmaremos lo que dice el Abate Raynal en la pintura que hace del carácter de nuestra nación de que "jamais peut étre aucune nation ne fut idolatre de ses préjugés, au point au l'etoient alors, ou le sont encore aujourd'hui les espagnols" etc.» ${ }^{183}$.

Robertson fue una de las víctimas de los motines protagonizados por los presbiterianos en 1779 -los motines Gordon- y Francisco Escarano ${ }^{184}$, destinado en la embajada en Londres, informó a Heredia de cómo el reputado historiador escocés «estuvo a pique de ver quemada su casa por sospechado partidario de los cathólicos. No estrañaré que esta nota se la haya ocasionado la defensa que hace en su historia del clero cathólico en América, y la idea en que están los más en Inglaterra de que ha vendido su piuma a la España. En estas circunstancias podrá servirle de consuelo la prohibición que se ha hecho ahí» 185 .

A pesar de haberse dedicado pacientemente a revisar la edición de la Historia de América, cuando tuvo noticia por medio del marqués de Torreblanca de que D. Miguel Gálvez se ocuparía de la impuganación de la obra, escribió a Roda el 1 de mayo de 1779: "Con esta noticia cerré el libro, y no lo he buelto a abrir más» ${ }^{186}$.

\section{LA PASIÓN POR LOS LIBROS}

Aunque no le falta razón a Isidoro Pinedo cuando anteponía la pasión que Roda sentía por la política a la que profesaba por la cultura, la dimensión del Ministro aragonés como erudito y bibliófilo, como «hombre de libros», es bien conocida ${ }^{187}$. La «notabilísima» biblioteca de Roda, que legó a su muerte con parte de su archivo particular al Seminario de San Carlos de Zaragoza ${ }^{188}$, se caracterizaba por ser, «con toda probabilidad» la «biblioteca antijesuítica más rica de su tiempo» ${ }^{18}$.

183. [Heredia - Roda], París, 5 de febrero de 1779.

184. Francisco Antonio de Escarano (1730-1794) Secretario de la Embajada en Londres desde 1768 y encargado de negocios durante las largas ausencias de Masserano (1772-1775) y de nuevo hasta la llegada del Duque de Almodóvar a Londres en julio de 1778.

185. [Heredia - Roda], París, 24 de febrero de 1779.

186. [Heredia - Roda], París, 1 de maio de 1779.

187. Roda era: «Hombre de libros [que] demostró sin embargo más pasión por la política que por la culiura; de la misma manera subordinó sus sentimientos de amistad a su trabajo al servicio de la Corona». PINEDO, 1. Manuel de Roda..., p. 185.

188. LASTRE, Luis. Manuscritos e incunables de la Biblioteca del Real Seminario Sacerdotal de San Carlos de Zaragoza. Zaragoza, 1943. Los valiosos manuscritos e incunables que recoge Lastre en esta obra pertenecían «a la Biblioteca de Roda», p. 6.

189. PINEDO, 1. Manuel de Roda..., p. 130. 
Roda supo y pudo servirse de los diplomáticos españoles acreditados en el extranjero para surtir a «su dama», conforme gustaba de donominar a su biblioteca, de ejemplares raros, curiosos, y claro está, también de las novedades editoriales que aparecían en Europa.

Ciertamente, el mercado de libros en las ciudades españolas, y en particular en la Corte, había cambiado respecto al más bien triste panorama de la primera mitad del siglo a juzgar por las descripciones del P. Sarmiento, de manera que las posibilidades de contar con libreros capaces de importar con agilidad libros desde Europa eran mayores, pero para conseguir determinadas obras resultaba recomendable una vía más directa $^{150}$.

En 1762 Roda, entonces Agente de Preces en Roma, escribió al embajador en París, Grimaldi, manifestándole su interés por «adquirir libros editados en Francia y Holanda y, sobre todo, en recibir noticia de primera mano acerca del proceso que en la nación vecina se había entablado contra los jesuitas y que iba a acabar con su disolución Por ello no dudó en dirigirse a Grimaldi, quien procuró satisfacerle buscándole buenos informadores: Antonio Navarro, recién nombrado secretario de la embajada de Holanda, para la compra de libros, y Francisco Carrión, quien según notificaba a Roda "me ha dicho que escribiría a V.E. cuanto ocurre en el día de los buenos Padres" $\gg 191$.

Resulta bien conocida la correspondencia que a lo largo de muchos años mantuvo Roda con quien fue su sucesor en la Agencia de Preces romana, el también aragonés José Nicolás de Azara, y en la que los asuntos «político-literarios» tienen un notable peso específico ${ }^{192}$.

Ya en Madrid mantuvo muy estrechas relaciones con los bibliotecarios reales, y de forma muy singular con el bibliotecario mayor y preceptor del Infante Francisco Pérez Bayer, quien, además de colaborar en la formación de la biblioteca de Roda, también aprovechó la vía ministerial, y los servicios del propio Ignacio de Heredia, para conseguir obras que difícilmente podían adquirirse en España ${ }^{193}$. A estas alturas Roda parecía haber dejado ya lejos la reflexión que hiciera a su amigo Juan Martín en 1762 con motivo de aconsejarle acerca de fomentar en los jóvenes el hábito de escribir bien, con letra clara y buena ortografía, pues, a él mismo le servía «de mucha

190. «Catálogo de algunos libros curiosos y selectos, para la librería de algún particular, que desee comprar de tres á quatro mil tomos. Por el R.P.M. Fray Martín de Sarmiento, Benedictino de Madrid». Semanario Erudito, Madrid (1787) V, pp. 97-174. Igualmente «Reflexiones literarias para una Biblioteca Real y para otras Bibliotecas públicas, hechas por el R.P.M.F. Martín Sarmiento, Benedictino, en el mes de Diciembre del año de 1743», Semanario Erudito, Madrid (1789) XII, pp. 99-273.

191. Grimaldi - Roda, París, 30 de marzo y 11 de mayo de 1762. B.N. Mss 7171, 1 y 8 . Apud. PINEDO, I. Manuel de Roda, p. 117. En 1 p. 130 vuelve a hacer referencia a la red de corresponsales que compraban libros para Roda «en París, Amsterdam y diversas ciudades italianas».

192. El espiritu de D. José Nicolás de Azara descubierto en su correspondencia epistolar con Don Manuel de Roda, Madrid, 1846, 3 vols.

193. En [Heredia - Roda]. París, 21 de junio de 1776 hace referencia expresa a la correspondencia con Pérez. Bayer: "No creo que al recibo de ésta se halle ya ahí Don Francisco Bayer, pues me escribe en 
mortificación el escribir de mi puño por hacer mala letra», por lo que había dejado «de escribir infinito, [1o] que después me ha pesado» ${ }^{194}$

El primero de octubre de 1773, apenas trascurridas tres semanas de su llegada a la entonces capital cultural de Europa, Heredia decía encontrarse ya en condiciones de comenzar sus pesquisas de bibliófilo y de llevar a cabo los encargos que el Ministro considerase oportuno hacerle, pues había empezado «a tener conocimiento... con los colporteurs».

Heredia, que sabía que Roda había adquirido algunos fascículos de la enciclopedia de Artes y Oficios, se apresuró a remitirle el índice de todos los que habían aparecido hasta entonces con la relación detallada de sus precios para que pudiese avisarle de los cuadernillos que le faltasen. A él mismo se le había presentado una buena ocasión de adquirir los primeros 42 fascículos, encuadernados en 8 tomos, y encargó a su proveedor que fuese «comprando de lance» los que encontrase para completar la obra al menor coste posible, añadiendo que «sabiendo los que le faltan a V.E. le haré la misma prebención» ${ }^{195}$.

El secretario de Aranda se mantuvo fiel a su palabra, remitiéndole en diversas ocasiones algunos cuadernos, y todavía en febrero de 1776, puesto que Roda le había solicitado ocho que le faltaban en su colección, le advertía Heredia: «...me admira le falten sólo los ocho que expresa la nota, quando después de éstos se han publicado otros muchos, y algunos el año pasado. En la lista que embié a V.E. noté los que se han publicado últimamente de los que estaban sous presse. Hágala V.E. reconocer nuevamente, pues no es posible que no le falten más de los que indica la nota; y en caso de que sea así podrá V.E. abisármelo para comprarlos» ${ }^{196}$.

No tardó tampoco mucho Heredia en ofrecer al Ministro sus oficios para alimentar la pasión de Roda por los autores jansenistas: «Si V.E. quiere alguna obra relativa al jansenismo no tiene sino abisar, porque me he hallado acá con un Soldevilla, Prior de San Martín de la Gacanne, hijo de mi lugar, que renunciaría desde iuego al priorato antes que subscribir el formulario, ni a la Bula Unigenitus, y tiene amistad con todos los gefes del partido. Le encargué que me buscara un confesor que supiera la lengua española, y me llebó ayer al Procurador general de los Trinitarios, con quien quedé citado para la víspera de la Concepción. Él me asegura que es jansenista a mi moda, pero yo temo no lo sea a la suya, en cuyo caso no me queda otra espe-

este correo que iba a partir para Valencia. Si por alguna casualidad estuviera aún ahí, puede V.E. dexarle ver el catálogo para que escoja los libros que necesite; y en caso de que haya partido, ruego a V.E. le mande dirigir esta carta. No tengo lugar para más, y se repite a las órdenes de V.E. su mayor serbidor y amigo».

194. «Copia de la carta que Don Manuel de Roda, siendo Auditor de Rota en Roma por la Corona de Aragón, dirigió a Don Juan Martín, con fecha de primero de junio de 1762, para la educación de sus sobrinos», Semanario Erudito, Madrid (1788), pp. 225-242.

195. [Heredia - Roda], París, 1 de octubre de 1773. Los 8 tomos de Artes y Oficios los adquirió por 230 libras, cuando sueltos costaban, según el índice de precios, 366 libras.

196. [Heredia - Roda], París, 10 de febrero de 1776. 
ranza sino la de que no nos entendamos, pues el tal Procurador es tan corta pala en la lengua española como yo en la francesa» ${ }^{197}$.

Heredia mostró siempre gran diligencia en solucionar los encargos de libros que le hacía Roda. En cartas de 24 de enero y 4 de febrero del 74 el Secretario de Gracia y Justicia le remitió algunas listas de libros en los que estaba particularmente interesado, y el 18 de ese mismo mes Heredia le daba cuenta de haberlos comprado ya todos, «a excepción de los dos tomos de Tabulae terra sanctae elucidatio ex collectaneis Gulielmi del'Isle ${ }^{198}$, cuya obra no se ha encontrado ni ay noticia de ella, no obstante que el sugeto a quien lo he encargado ha estado con Mr. Buache, que compró todas las obras y papeles que dejó en su muerte del'Isle, quien le ha dicho que éste havía hecho algunos mapas de la Tierra Santa pero no obra que comprendiera dos tomos en quarto. No quedo plenamente satisfecho de esta respuesta porque el título de la obra no dice que la haya hecho del'Isle, y puede muy bien ser de otro; por lo que haré repetir nuevas diligencias en su solicitud, y si V.E. gusta podrá darme las noticias que tenga del autor, o lugar de la impresión. Las obras de San Máximo y San Gregorio Thaumaturgo ${ }^{199}$ son raras acá, especialmente las de San Gregorio, que se han hallado de casualidad y las han hecho pagar caras. De Artes y Oficios he comprado los tres quadernos que V.E. me pedía y ocho más nuevamente publicados. De todo incluyo a V.E. la lista que me ha traído el colporteur con sus precios, de cuyo total le he rebajado 15 libras, y queda reducida a trescientas catorce y media libras o pesetas, que si V.E. gusta podrá mandarlas entregar en Madrid a D. Joaquín Prior, Teniente del resguardo de la Corte, que vive al lado del quartel de Guardias Walonas.

Oy o mañana saldrán de aquí estos libros para [El] Havre de Gracia con los que embia Fournié a D. Vicente Blasco, a quien me ha dicho Fournie que lo abisaría en este mismo correo» ${ }^{200}$.

Por lo general, las noticias de las obras interesantes que llegaban a manos de Heredia -quien, según Aranda «lee que se quita el pellejo, pero no adelanta en petitmai-

197. [Heredia - Roda], París, 3 de noviembre [tachado, por diciembre] de 1773. Al tiempo le decía que Aranda se había alegrado de recibir noticias suyas, pues estaba receloso de haber perdido su confianza. Aranda, por su parte tenía ya preparados «varios Mapas» para enviárselos a Roda cuendo se proporcionase la ocasión.

198. Guillermo Delisle (1675-1726) hijo y discípulo del también geógrafo real Claudio Delisle (16441720) se le atribuye el haber rectificado el sistema de representación cartográfica de las longitudes de Ptolomeo en la representación de los continentes. Luis XV le concedió el título de Primer Geógrafo Real. Miembro de la Academia de Ciencias de París desde 1702.

199. S. Gregorio Taumaturgo. Gregor. Neocaesariensis episc. Cognomento Thavmatur... Macarii Aegyp et Basilii Seleuci Isauriae Episcopi. Opera omnia, quae reperiri potuerunt. Nunc primun Graece et latine coniunctim edita cun indicibus necess, Accesit Joannis Zonarae Expositio Canonicarum Epistolarum reliquarum canon Commentrio subiugenda. Parisiis, MDCXXI [1621], cum privilegio Regis. Existe otra edición de 1625.

200. [Heredia - Roda], París, 18 de febrero de 1774. 
tre ${ }^{201}$ - aunque estuviesen relacionadas con sus labores en Ia Embajada, llegaban también a manos de Roda.

El 20 de enero de 1774 le escribía: «La semana pasada dexaron en mi quarto todos los quadernos que ha publicado el abate Gorier de su Diario Observations sur la Phisique, sur l'histoire naturelle, et sur les Arts, con una carta dirigida al Presidente y miembros de la Academia de las Ciencias de Madrid. Como ahí no ay tal Academia abrí la carta y vi que se dirige a solicitar la correspondencia con ella y la comunicación de sus descubrimientos sobre los objetos de su Diario, como lo verá V.E. por la copia que incluyo, la qual hace ver que esta obra está apoyada del Ministerio, lo que he sabido por otra parte.

En estos términos nos ha parecido que el único partido que havía que tomar era embiarlo todo al Sr. Marqués de Grimaldi, como lo exequta S.E., por si quiere embiar la carta a alguna de las Academias de ahí o algun otro sugeto, versado en los asuntos que trata.

Para que V.E. pueda formar idea de este Diario incluyo algunos exemplares de su prospectus, y el Índice de los artículos que contienen los doce primeros volúmenes» ${ }^{202}$.

El encargo de los mapas de Tierra Santa llevó de cabeza a Heredia por una larga temporada, en la que que se afanó en pesquisas con los eruditos libreros de París. En los primeros días de abril escribía al respecto: «He hecho hacer nuevas diligencias sobre la obra de Guillelmo del'Isle, pero han sido inútiles, y a mi me parece que la Nota que V.E. me embía da a entender que los dos tomos en $4\left[^{\circ}\right]$ de Collectaneas no se han impreso jamás, y que se conserban manuscritos en el Archivo Geográfico de la Marina de este reyno.

El sugeto a quien encargué la averiguación me dixo que havía visto una carta geográfica de la Tierra Santa con su explicación en un quadernillo de pocos pliegos, y aunque por entonces no creí que pudiera ser esta la obra por tener yo en mi cabeza.

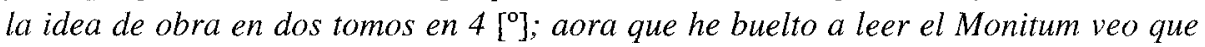
sin duda alude a ella quando dice: "Hicius tabulae elucidatio scorsim est edita ex collectaneis Guillelmi de l'Isle, propria que eius manu scriptis in 2 vol. in 4. Que quide collectanea in re navalis archivo geographico conserbantu". Haré ver denuevo esta explicación, y si es a la que alude el Monitum se la embiaré a V.E. por el correo, como lo exequto ahora con las Horas militares que me pidió» ${ }^{203}$.

El 20 de abril Heredia había solucionado por fin el enigma: «Me han trahído el Mapa de la Tierra Santa y su explicación, y he hallado que es lo que buscábamos. Por estar la explicación en quarto grande la he incluido en un paquete que embio al Conde de Rebillagigedo prebiniéndole la entregue a V.E. No he incluido el mapa

201. Aranda -Roda, París, 20 de noviembre de 1774 [Autógrafa].

202. [Heredia - Roda], París, 20 de enero de 1774.

203. [Heredia - Roda], [París, sin fecha. Primeros meses de 1774, probablemente abril]. 
porque con las dobleces se hecharia a perder, y porque veo que ya lo tiene V.E. en el Atlas de Mr. Bonne ${ }^{204}$; pero si V.E. lo quiere lo remitiré en la primera ocasión» ${ }^{205}$.

Poco antes, el 18 de febrero, le había informado de la nueva edición de Bossuet que estaba realizando el abate Boudet: «Ya sabrá V.E. que Boudet hace una nueva impresión de las obras de Bosuet, en la que havrá muchos tratados que hasta aquí no se havian publicado, de modo que cuenta con que la edición tendrá 28 o 30 tomos en $4\left[^{\circ}\right]$. De esta clase son los sermones los que bende sueltos en tres tomos en $4\left[^{\circ}\right]$ para que puedan comprarlos los que tienen la antigua edición de Paris, y en $\left.81^{\circ}\right]$ para la de Aviñón; con que si V.E. tiene alguna de ellas y los quiere podrá abisármelo, y expresar si los he de embiar en papel o encuadernados» ${ }^{206}$.

En respuesta a una carta de Roda de 7 de marzo, en que le había comunicado entre otros asuntos la muerte del Infante, Heredia retomaba la cuestión de la edición de Bosuet: «La reimpresión de Boudet de las obras de Bosuet va muy larga según me ha dicho él mismo. Hasta aquí ha publicado seis tomos, y en todo este año dará a luz. otros seis. Yo he suscrito pagando los seis, y anticipando el precio de los otros seis a razón de 10 libras cada tomo en papel; de donde resulta que si la obra tiene 30 tomos costará 300 libras. La antigua edición de París cuesta 180 libras; y los tres tomos de sermones encuadernados $45 \gg^{207}$

Las noticias acerca de las novedades literarias van apareciendo con cadencia irregular en la correspondencia. En los primeros días de abril Heredia le anunciaba la aparición de la traducción francesa de «la historia de los viages que han hecho quatro capitanes ingleses a la mar del Sur, en quatro volúmenes en $4\left[^{\circ}\right]$ con láminas, su precio en cartón 54 libras. He comprado un exemplar para Estado, y lo embiaré la semana que biene con los 50 exemplares del tomo 16 del Diccionario de Sabbathica, que se ha publicado» ${ }^{208}$. Roda debió mostrar interés por la obra de los viajes del capitán Cook, pues Heredia se la remitió en el mes de mayo por mano de Iriarte ${ }^{209}$.

204. BONNE, Rigobert. Atlas encyclopédique, contenant la géographie anciene et quelques cartes sur la géographie du moyen âge, la géographie moderne et les cartes relatives a la géographie physique, par Bonne ... et par Desmarest; [Première Partie]. A Paris: Hôtel de Thou, 1787 (A Orléans: de l'Imprimerie de Couret de Villeneuve), 65 p., 77 h. de mapas; $4^{\circ}$. Atlas encyclopédique, contenant la géographie anciene et quelques cartes sur la géographie du moyen âge, la géographie moderne et les cartes relatives a la géographie physiquel par Bonne ... et par Desmarest ... ; [Seconde Partie]; A Paris : Hôtel de Thou, 1788. Naturalmente, Heredia se refiere a una edición anterior que no he podido localizar.

205. [Heredia - Roda], París, 20 de abril de 1774.

206. [Heredia - Roda], París, 18 de febrero de 1774. En el inventario de los libros que Heredia compró en París, aparecen los Discours sur l'histoire universelle, París, Imp. Didot l'âine, 1884, 1 vol en $4^{\circ}$, y las Oeuvres de la nouvelle édition. Paris, s.f., 6 vols in $4^{\circ}, 73$ libras y 10 sueldos.

207. [Heredia - Roda], [París, sin fecha. Primeros meses de 1774, probablemente abril].

208. [Heredia - Roda], [París, sin fecha. Primeros meses de 1774, probablemente abril].

209. [Heredia - Roda], Versailles, 6 de mayo de 1774 . El 26 de mayo acusaba recibo de la carta de Roda en la que le confirmaba el recibo de los los «quatro tomos de los viages» $\mathrm{y}$, según parece, atendía también la solicitud del Ministro para que le informase del precio, cuyo monto ascendía a 53 libras. 
También Aranda se mostró obsequioso con Roda, regalándole mapas, libros y láminas en diversas ocasiones ${ }^{210}$. El 18 de febrero le informaba Heredia que: «S.E. me ha dado para que lo dirija a V.E. un tomo muy grande de Anathomia, obra digna de la librería de V.E., y algunas cartas geográficas y genealógicas, que se ha llebado oy Fournie para dirigirlas con los demás libros; y me ha dicho S.E. que dixera a V.E. ha recibido su carta, y que responderás ${ }^{211}$.

Sin embargo, el Conde, que podía ser muchas otras cosas, no era precisamente un hombre versado en el sutil arte de regatear con los libreros. Aunque en una ocasión escribera a Roda que «Don Iñigo y yo andamos entre libreros, cada uno por las ramas que le convienen ${ }^{212}$, Heredia se permitía bromear con Roda acerca del escaso olfato del Conde para tratar con los colporteurs, pues Su Excelencia decidió acompañarle a recorrer algunas almonedas aprovechando la primavera parisiense, pero «como no estaba acostumbrado a estas armas pagó el aprendizage; pero lo que le voló sobre todo fue el que un libro que le costó 27 pesetas, lo compré yo en la misma librería pasados dos dias por 3. Con todo dice que no ha tenido tarde más dibertida en París» ${ }^{213}$.

Heredia se ocupó también de enviar al Ministro inventarios y repertorios que se habían convertido ellos mismos en raras guías para bibliofilos. «Tengo en mi poder - escribía Heredia el 6 de mayo- los dos Cathalogos del Abbé de Rothelin, y Mr. de Bore, cada uno en un tomo regular de lo que acá llaman octavo; pero tan caros que el de Rothelin no quieren darlo [por] menos de 25 libras, y 12 el de Bore, por lo que no me he resuelto a comprarlos hasta informarle a V.E, y aguardar sus órdenes. Los dos exemplares tienen la particularidad de estar apuntados al margen los precios a que se bendieron los libros, lo que es muy apreciable el aumento que se ve tuvieron los precios desde el año de 1746 en que se bendió la librería de Rothelin, hasta el de 53, que fue la venta de la de Bore. La de éste no era tan copiosa como la de Rothelin, pero le hacía infinita ventaja en lo raro de las obras y de las ediciones, y admira el ver pagar tres mil libras de una Bíblia impresa en dos tomos; y dos mil de un código de sólos los Psalmos, impresas las dos obras en Maguncia por Fust y Schoiffe en 1457 y 62. El libro de Serveto Christianismi restitutio, que según dice el cathálogo es

210. «Voi juntando algunos mapas como tengo ofrecido a V.E. Hasta ahora con sólo disponer mis cosas de establecimiento tengo bastante en que pensar». Aranda - Roda, París, 2 de octubre 1773. [Autógrafa] «Con una remisión de libros que me dice Heredia está para hacer, remitiré a V.E. diferentes mapas átiles para el estado presente de Europa, y un árbol genealógico mui grande de la familia Borbón moderno». Aranda - Roda, París, 20 de enero 1774. [Autógrafa].

211. [Heredia - Roda], París, 18 de febrero de 1774. El tratado a que se refiere puede ser el de ALBIN, B. Sigfrid [Albinus] Tabulae squeleti et musculorum corporis humani, Lyon, 1747, 1 vol. in folio con láminas, o Tabulae ossium humanorum, Leyden, 1753, 1 vol. In folio. Heredia commpró para su biblioteca ambos ejemplares en París.

212. Aranda -Roda, París, 30 de septiembre de 1774.

213. [Heredia - Roda], París, 6 de mayo de 1775. 
el único que ay, se vendió en 1.200 libras. Oy lo tiene el Duque de la Valiere y le costó 3.000 ${ }^{214}$. El Misal y Brebiario mozárabe se bendieron en 3.000» ${ }^{215}$.

El 2 de julio todavía estaba pendiente el envio de los eruditos inventarios de Bore y Rothelin: «No se si el correo podrá llebar los dos tomos de los Índices porque ay muchos paquetes que embiar. Lo diré en postdata. Ya dixe a V.E. que en los dos están los precios a que se bendieron los libros por libras y sueldos; pero para inteligencia del de Mr. Boré es preciso saber que su librería se bendió por junto a una mano, bajo el precio en que los tasó el famoso librero Martin, haviendo dado facultad al comprador de dexar los que no quisiera. Por eso ay dos Índices, el primero es de toda la librería con los precios de la tasa, a que pagó el comprador los que no descartó. El segundo es de los que dexó y se bendieron después por menor a los precios que están anotados. En el de Rothelin nada ay que advertir porque toda su librería se bendió por menor al estilo de este país, que es al más dante, y por eso advertirá V.E. tantos sueldos impares en los precios» ${ }^{216}$.

El envio de los libros presentaba a menudo problemas, y Heredia, salvo que pudiese utilizar los correos extraordinarios para encomendarles algún libro, procuraba juntar un buen número de volúmenes para remitirlos con mayor seguridad y menor coste, generalmente, aprovechándose de algún librero como intemediario. Así, por ejemplo, el 26 de mayo escribía: «Supongo que ya havrá recivido V.E. los libros que embió Fournier, pues haviéndolo recombenido me dixo que a D. Vicente Blasco le havia hecho dos remesas, y que los de V.E. iban en la segunda, que sabia havía llegado a Bilbao» ${ }^{217}$.

La correspondencia entre ambos personajes discurre a menudo por los poco frecuentados caminos de la erudición bibliográfica. Roda, sin duda tenía noticias del catálogo de Bore, pues le preguntó a Heredia acerca de la existencia de otra edición distinta de la que le había enviado. Heredia, por su parte, afirmaba su autoridad en la materia: «No he hallado noticia de que haya havido otra impresión de la Bibliotheca de Bore que la que le embié a V.E.; y tengo por una prueba conbincente de ello el que no se halla impreso su cathálogo en el artículo que ay de Bibliothecas, lo que ciertamente huviera sucedido si el lo huviera hecho imprimir. No se han podido hallar las cartas de M[adame] Pompadour, que se bendieron de contrabando a 30 y 36 libras. En días pasados vi un Prospectus de las obras de Antonio Arnau[l]d que se van a imprimir por subscripción en Lausana en 30 tomos en $4^{\circ}$; pero como V.E. no gusta de subscripciones no he cuidado de solicitar un exemplar» ${ }^{218}$.

214. En carta de 10 de julio de 1776 rectifica esta información: «También he sabido que su librería lla de Bore] la compró el Presidente Cotte, que oi vive, y que en su poder, y no en el del Duque de la Baliere, está el famoso libro de Serveto Christianismo restitutio».

215. [Heredia - Roda], París, 26 de mayo de 1774.

216. [Heredia - Roda], Marly, 2 de julio de 1774.

217. [Heredia - Roda], París, 11 de mayo de 1774.

218. [Heredia - Roda], París, 4 de agosto de 1774. Antoine Arnauld (1612-1694), uno de los más destacados representantes del movimiento jansenista, defensor de las tesis agustinianas sobre la gracia y po- 
A veces las peticiones de Roda eran incluso prematuras. En mayo había mostrado interés por que Heredia consiguiese en París lo que Roda calificaba como el «poema» de Guilleaume, es decir, la Apologie ou Défense du trés ilustre Prince Guilleaume Prince d'Orange, atribuida a Pierre Loyseleur de Villiers, editada en Amberes en 1581, cuyo extracto había aparecido en los periódicos, pero Heredia no pudo cumplir por entonces el encargo, pues, la obra no había llegado todavía a París, o al menos no se hallaba venal ${ }^{219}$. De nuevo los comentarios de Heredia se centraban en el desconocimiento acerca de la historia española: «Estas gentes no saben, ni conciben de Phelipe $2^{\circ}$ sino lo que leen en los escritos de sus enemigos, y juzgan de todo según las ideas y costumbres con que oy viven» ${ }^{220}$.

Por fin en julio de 1775 Heredia localizó, conforme Roda sospechaba, otra edición del catálogo de Bore: «Me acuerdo que quando embié a V.E. el catálogo de Mr. Bore dixe que no se havía impreso en folio, porque así me lo informó el librero que me lo vendió. Aora puedo decir a V.E. que he visto bender un exemplar de este tamaño en una almoneda; y con este motivo he averiguado que Mr. Bore hizo imprimir en vida cinquenta exemplares en folio pequeño para repartirlos entre su Amigos, y se apreció tanto que mientras él vivió huvo exemplar que por muerte del sugeto a quien lo havía regalado, se bendió en almoneda en 250 libras. Después de su muerte, como se imprimió el pequeño, ha decaído mucho su precio, pero todavia se conserba entre 50 y 60 libras. También he sabido que su librería la compró el Presidente Cotte, que oi vive, y que en su poder, y no en el del Duque de la Baliere, está el famoso libro de Serveto Christianismo restitutio. En el catálogo pequeño de Bore, que yo he comprado, se advierte por una nota manuscrita, que tasaron separadamente los libros de David y Martin, y está puesta la tasa de cada uno en los muchos artículos en que discreparon, lo que no me acuerdo si se halla en el de V.E.» ${ }^{22}$

El 20 de noviembre enviaba dos nuevos catálogos de libros «que se benden con rebaja de su antiguo precio, por si su baratura lo tienta a V.E. como me ha sucedido a mí, que he tomado muchos, en cuyo caso podrá V.E. embiarme la lista de los que quiera, y los remitiré en papel que es como los benden. No tengo lugar para más que repetirme a la obediencia de V.E. su mayor serbidor» ${ }^{222}$.

De los negocios de Heredia en Madrid se ocupaba su apoderado Joaquín Prior, Teniente de las Guardias Valonas, que fue el encargado de ir liquidando las cuentas

Iemista antijesuita. Entre sus obras más destacadas se citan Téologie moral des Jesuites (1643), De la frèguente comunión..., Apologie pour les Saints Pères de l'Eglise, defenseurs de la grâce de JésusChrist contre les erreurs qui leur sont impossées..., y otras sobre Lógica (1662), Gramática general (1661), Impieté de la moral des calvinistes... (1675); Apologie pour les catholiques... (1681). Sus Obras completas fueron reunidas y editadas por el abad de Hautefage, Lausana, 1775, en 45 vols.

219. [Heredia - Roda], Marly, 2 de julio de 1774. GARCÍA CÁRCEL, R. La leyenda negra. Historia y opinión Madrid, 1992 (1998, 2a), pp. 36-37.

220. [Heredia - Roda], París, 6 de junio de 1774.

221. [Heredia] - Roda. 10 de julio de 1775.

222. Heredia - Rodal, París, 20 de noviembre de 1774. 
pendientes entre los dos aragoneses ${ }^{223}$. El 12 de enero el apoderado de Heredia remitió a Roda una carta que, al parecer por una confusión fue a parar a sus manos ${ }^{224}$, y en la que el Secretario de la Embajada en París le informaba del partido que le había sacado a estas últimas almonedas: «Remito a V.E los dos tomos que me ha pedido de la historia de los estados barbarescos, cuyo precio es de cinco pesetas, pero no tiene V.E. que entregarlas, porque lo pondré en cuenta quando V.E. me de otros encargos.

En esta Quaresma se han vendido algunas librerias buenas, y haviéndome hallado algunas tardes en sus almonedas (que aqui se hacen por obra al que más puja) he comprado varios libros, algunos de ellos con la mira de embiarlos a V.E. en caso de que no los tenga y sean de su gusto, pues por lo que mira al precio son baratos. Son la Historia del Concilio de Trento de Fra Paolo [Sarpi] por el Padre Courayer ${ }^{225}$, en tres tomos en quarto, bien tratados y de buena edición; la Historia del Concilio de Constanza de L'Enfant en francés, en dos tomos en $4\left[^{\circ}\right] ;$ y la del de Pisa por el mismo en otros dos tomos en $4\left[^{\circ}\right]$. Estas tres obras las compré juntas por 28 pesetas ${ }^{226}$. La obra de Edmundo Richer de Eclesiastica et política potestate con su defensa, en dos tomos en $4\left[^{\circ}\right]$, y la del mismo, Vindiciae doctrine majorum schola parissiensis, en otros dos en $4\left[^{\circ}\right]$, costaron 10 pesetas ${ }^{227}$. Launoi, Regia in matrimonium potestas, la impugnación de este tratado, y su defensa, en 3 t[omos] en $4\left[^{\circ}\right]$; y otro tratado del mismo, Traditio circa simoniam ${ }^{228}$, en 1 vol, en $8\left[^{\circ}\right]$, costaron siete pesetas.

223. [Heredia - Roda], París, 6 de junio de 1774.

224. «Excmo Sr: Muy Señor mio: Oy he recivido carta de Don Ignacio de Heredia, de quien soy apoderado, y en ella, la que acompaño para V.E., incluida, sin duda, por equivocación de quien cerró el pliego, porque nada me previene. Sólo esta casualidad, u otra equivalente, podia alentarme a hacer presente a V.E., por este medio, mi veneración y respeto a su persona». Joaquín Prior - Excmo Sr. D. Manuel de Roda, Madrid, 12 de enero de 1775.

225. COURAYER, P. F. De (Ruan 1681-Londres, 1776). Teólogo francés. En 1723 publicó una disertación anónima en la que defendía la validez de la sucesión apostólica en la Iglesia Anglicana, que fue condenada por el Arzobispo de París y por el abad de Santa Genoveva a cuya congregación pertenecía. Tras publicar una carta en el Journal des Savants reconociéndose autor de la obra condenada se retiró a Inglaterra. Su Histoire du concile de Trente, en París, en 1751 y 1768, 3 vols, en $4^{\circ}$.

226. LENFANT, Jacobo Carlos (1661-1728). Pastor de las iglesias de Heidelberg y Berlín. Publicó la Histoire du Concile de Trente, Asterdarm, 1714 y los aludidos Histoire du Concile de Constance, Amsterdam, 1727. Histoire de la guerre des Hussites et du Concile de Bâle, Utrecht, 1731. Histoire dit Concile de Pise, Utrecht, 1731.

227. RICHER, Edmond (1559-1631) defensor de tesis galicanas condenadas en 1629, editor y apologista de Gerson. Su obra más polémica fue De ecclesiastica et politica potestate libellus, Paris, 1611. La obra a que se refiere Heredia contenía también la defensa que realizó contra los belaminianos el propio Richer: Demonstratio libelli de ecclesiastica et politica potestate, Parinsis primun edita anno 1611 , in quo praedictus libellus refertur integer, majus culislitteris excudintur et demostratur, Paris, 1622. La otra obra es Vindiciae doctrinae majorum scholae Parisienis seu constans et perpetuct scholae Parisiensis doctrina de auctoritate et infallibilitate Ecclesiae in rebus fidei et morum, contra defenores monarchiae universalis et absolutae Curiae romanae, Colonia, 1683, 1 en 12. D.T.C. 2698-2702.

228. LAUNOY, Jean de (1603-1678) Desde 1643 el Canciller Séguier le designó uno de los cuatro censores regios encargado de suprimir los libros en que se propagaban las doctrinas de Jansenio y Arnauld. 
Si V.E. los quiere todos, o alguno de ellos, con su aviso los remitiré en la primera ocasión que se presente» ${ }^{220}$.

La preocupación por algunos grupos de marginados se manifiesta en la correspondencia en abril de 1774 con ocasión de exponer a Roda la admiración que le había producido la labor que desarrollaba el abate L'Epée, quien sistematizó un método de enseñanza y de expresión por señas para los sordomudos, además de perfecciónar un sistema taquigráfico. Heredia remitió al Ministro el «exercicio de Mudos y Sordos que tuvo el abbate de L'Epée en su casa el año pasado, a fin de que pueda V.E. juntarlo por apéndice a nuestro Bonet ${ }^{230}$. Todo quanto dice lo havemos visto practicar S.E. y todos los de la casa, que quedamos pasmados al ver que unas muchachas escribian una misma cosa en quatro lenguas con tanta velocidad y exactitud de puntuación y ortographía como puede hacerlo un maestro de la propia. El méthodo de este abate es muy superior al de Bonet y Pereira, pues éstos sólo tiene signos para las letras del abecedario, y en una palabra es menester que hagan tantos como tiene letras; pero el abate sólo emplea uno para cada cosa, y como lo toma de la naturaleza da a conocer la idea que debe formarse de ella. Las circunstancias que concurren en este insigne hombre demuestran que Dios lo ha criado para alivio de estos infelices. Me han asegurado que de bienes propios y de sus beneficios compone más de cincuenta mil libras de renta, de la que emplea mucha parte en socorro de sus discípulos pobres. Su paciencia, candor y humildad son admirables. Tiene un gran talento para las lenguas, pues sólo con el socorro de los diccionarios y para poderlas ense-

Reputado autor de obras de crítica, historia y disciplina eclesiástica. El abate Granet publicó sus obras completas: Joannis Launoi opera omnia, ad selectum ordinem revocata, ineditis opusculis aliquot, notis nonnullis dogmaticies, historicis et criticis, auctoris vita, variis monumentis tum ad Launoium, ium ad scxripta ipsius pertinentibus, praefactione cuique volumini offixis, indicibus locupletissimis aucta et illustrata. Accedit Tractatus de varia Launoii librorum fortuna, 5 vols. en 10 tomos in fol. Genève, 1731-1733. Seguidor de las doctrinas agustinistas acerca de la gracia, mantuvo posiciones muy críticas respecto al jansenismo doctrinal. Como polemista Launoy adquirió una notable reputación como refutador de las falsas tradiciones piadosas, mostrándose especialmente combativo contra el principio de la infabilidad pontificia, defendiendo por el contrario la de los concilios. criticando las doctrinas de Cayetano y de Belarmino. Contrario igualmente a considerar dogmática la inmaculada concepción de María. Entre sus estudios históricos acerca de los sacramentos su obra más polémica fue Regia in matrimonuim potestas vel tractatus de jure saecularium principum christianorum in saciendis impedimentis matrimonum dirimentibus, Paris, 1674, en el que, con ocasión del matrimonio de Gastón d'Orleans, defendía que el matrimonio era un contrato civil, en el que la autoridad secular tenía el derecho de establecer «des empêchements dirimants, même depuis que l'Eglise a élevé ce contrat ì la dignité de sacrement, et l'Eglise n'a aucum pouvoir sur ce punt». La impugnación a que se refiere debe ser la de Domingo Galésius, obispo de Ruvo (Nápoles), publicada en Roma en 1676, a la que Launoy respondió con la obra Contentorum in libro sins inscripto: Dominici Galesii...eclesiastica in matrimonum potestas, erratorum index locuplentissimus, Paris, 1677, en $4^{\circ}$. La obra de Launoy fue condenada por Roma en 1688. D.T.C. IX-16.

229. Adjunta a la citada de Prior. Probablemente es de finales de diciembre o primeros días de enero de 1775.

230. BONET, Juan Pablo, Reducción de las letras y arte para enseñar hablar a los mudos. Madrid, por Francisco Abarca de Angulo, 1620, $4^{\circ}$. 
ñar a los mudos ha aprendido cinco u seis de las vivas y la griega. Su zelo para propagar esta enseñanza toca casi en fanatismo, pues no pierde ocasión de instar oportuna e importunamente a los Ministros de acá, y a los extrangeros para que lo establezcan en todas partes. Viendo yo las vivas solicitudes con que atacaba a S.E., persuadi a un muchacho que traxe de ahí, y me lo dió Borques, a que se dedicara a esta arte, y en efecto ha empezado su curso hace ocho dias con tanto gusto de mi buen abate, que se promete formar en él en seis meses un maestro de la nación española, y me ha pedido por un gran fabor que no le embarace el que pueda concurrir todas las mañanas a su casa. La última vez, que bino a ver a S.E. nos dixo que si encontrara un sordo mudo de nacimiento, que huviera quedado ciego a los seis u ocho años, emprendería su instrucción por medio del tacto, pero que no havía podido hallarlo sin embargo que Mr. Sartine havía practicado a su instancias las diligencias» ${ }^{231}$.

Casi un año más tarde informaba a Roda que el «Abate l'Epëe [sic] ha dado al público su méthodo de enseñar a los sordos y mudos, y me ha embiado tres exemplares para el Príncipe, el Sr. Infante Don Gabriel y V.E., los que le he ofrecido embiar. Si un mercader que llebará esta carta quiere encargarse del paquete los embiaré con él; y quando no, los remitiré uno a uno por los correos ordinarios, y V.E. podrá darlos como la otra vez a Bayer y Pisón, o como mejor le parezca a V.E.» ${ }^{232}$.

En los primeros meses de 1775, aunque la atención de los enviados españoles en París estaba centrada en la pugna abierta entre el Gobierno y el Parlamento, y con Heredia más cargado de trabajo que en otras ocasiones, no sólo no había dejado de lado el envio obras para Roda, sino que se dedicó también a deshacer algunos entuertos y dar por falsa la colección de las cartas de la Pompadour, que Roda le había solicitado algún tiempo atrás: «Aora me ocurre lo que se me ha olbidado muchas veces, de decir a V.E. que las cartas de madame Pompadour son supuestas, lo que confirmé por uno a cuyo nombre, y de su muger, ay muchas, que es el Conde, o Marqués de Baschi, quien me dixo que ni una palabra havia de verdad» ${ }^{233}$.

Ya nos referimos a que los problemas derivados de la muerte de Luis XV, del abastecimiento de harinas y las polémicas sobre los precios tasados habían recobrado nuevo vigor, tanto en Francia como en España. El 3 de enero de 1775 Heredia avisaba a Roda que hacía algunos días que Aranda le había dado «unas Memorias que se imprimieron acá el año de 69 sobre el govierno de las rentas de la Francia, para que las remitiera a V.E.; pero como son quatro tomos en quarto y los correos van siempre cargados no pueden llebarlas, y será preciso aguardar a embiarlas con la remesa que se haga a algún librero de ahi» ${ }^{234}$. Pero hasta el 30 de marzo de 1775 no se presentó ocasión de remitir los tomazos sobre las rentas de Francia: «En una remesa de libros que ha embiado un comisionado de acá a Alfonso la Higuera, van los quatro tomos de las Memorias sur les finances de este reyno, de que tengo hablado a

231. [Heredia - Roda], París, 20 de abril de 1774.

232. [Heredia - Roda], París, 12 de diciembre de 1775.

233. [Heredia - Roda], París, 3 de enero de 1775.

234. [Heredia - Roda], París, 3 de enero de 1775. 
V.E.; y he hecho prebenir a la Higuera que los dirija a V.E. luego que los reciba. Es obra interesante para el conocimiento de esta monarquia; y si V.E. tiene lugar para recorrerlos por mayor verá que todos los proyectistas del tiempo de Phelipe $4\left[^{\circ}\right]$ eran niños de teta en comparación de los arbitristas de acá; y quedará asombrado de la multitud de impuestos y de empleos que han imbentado para sacar dinero. Por estos medios han puesto esta Monarchía en estado de no poder lebantar cabeza, sino dando enteramente por el pie al sistema actual, y refundiendola de nuevo, lo que no sucederá en el reynado presente, que será muy débil, según el conocimiento que vamos adquiriendo cada día» ${ }^{235}$.

A pesar de la crisis o guerra de las harinas que se produjo en Francia en la primavera de 1775, con asonadas y motines en París y provincias, como consecuencia de la carestía el pan, Heredia no perdía de vista sus ocupaciones de bibliófilo, y en la misma carta en que acababa de describir los motines, las medidas militares adoptadas por el Gobierno y los relevos que conllevó en puestos claves, escribía: «Puede V.E. enbiarme la Lista de los Libros que le faltan que yo tendré el cuidado de comprarlos quando haya ocasión. Aora se han bendido excelentes librerías, y casi las más de las tardes del mes de abril ha sido mi diversión el concurrir a ellas, lo que me ha costado muchos quartos. (...) y es cierto que en las tales ventas se ve a donde llega la locura de estas gentes. En su presencia se vendió un Tácito de Brotier ${ }^{236}$ impreso en esta villa en 1771 en 4 tomos en $4\left[^{\circ}\right]$ carta máxima que biene a ser como el Salustio del Sr. Don Gabriel, en cuya forma de papel sólo se imprimieron 25 exemplares, que se bendieron luego a 140 pesetas: los de papel ordinario se hallan en todas las tiendas de los libreros por 90 pesetas; pues este exemplar por sólo tener dos dedos más de margen subió a 501, y havía seis u ocho libreros que lo pujaban como leones. Otro libro intitulado Ars moriendi, impreso por Joannem Costerum sin data, pero que se crehe de los primeros años de la imbención de la imprenta, compuesto de 24 hojas en un octavo igual al dozavo de acá, se bendió en 1.070 libras. Otro en alemán intitulado Fewrdanncths [sic, por Theuerdank], o las aventuras del famoso héroe y caballero Fewrdanncths, por Melchor Pfintzing con figuras en madera de Alberto Durero, impresos en Nuremberga en 1517 en folio, subió a 1.010 libras. En siendo libro raro, que tenga estampas o buena edición no ay fuerzas, de modo que yo he cobrado ya horror a todo libro que lo veo señalado en el cathalogo cum figuris, marroquin rouge, belle épreuve, o carta magna» ${ }^{237}$.

Roda le había prevenido de que faltaba en su biblioteca la Historia del Concilio de Basilea, de Lenfant, y a Heredia se le presentó la ocasión de comprar «un bello

235. [Heredia - Roda], París, 30 de marzo de 1775.

236. BROTIER, Gabriel (1727-1789) Exjesuita y bibliotecario del Colegio de San Luis el Grande. Son conocidas sus excelentes ediciones anotadas de las obras de Tácito (París, 1771) - C. Cornelii Taciti opera / supplementis notis et dissertationibus illustravit Gabriel Brotier, anot. Delatour, Louis Denis, imp Edición: Parisiis : ex typographia L.F. Delatour ..., (1776). Theatre d'Aristofane / traduction françuise d'André Charles Brotier; revue et corrigée precedée d'une introduction et augmentée d'une notice sur chaque piè ce par Louis Humbert. Paris, Librairie Garnier, Frères, [s.a.] (Imp. Hemmerlé, Petit et Cie.); de la Historia Natural de Plinio (1779), y la obra Sur les Jardins Paris, 1779.

237. [Heredia - Roda], París, 6 de mayo de 1775. 
exemplar en papel grande» en una almoneda por 12 pesetas, y que, al igual que en otras ocasiones, remitió a Roda por vía de Alfonso la Higuera. Heredía se refería también a los libros que había podido encontrar de una nueva lista que Roda le había remitido el 12 de junio: «sólo he hallado hasta aquí l'historia de Pierre de Montmaur de Salengre ${ }_{2}$ en dos tomos en [12]; pero en ella tiene V.E. las dos piezas de Menage ${ }^{238}$, y todas las que escribieron contra Montmaur con las mismas estampas con que salieron las obras originales; por lo que omitiré el buscar separadamente las piezas de Menage, que sobre la dificultad de hallarlas, serían muy costosas por la furia con que buscan estas gentes las ediciones originales de las obras de alguna antigüedad ${ }^{239}$.

A mediados del mes de julio Heredia había podido satisfacer buena parte de las demandas de Roda: «En los correos anteriores he embiado a V.E. los tres tomos sobre granos de Necker; respuesta a éste del Abate Beaudau; y otra al Abate Galiani ${ }^{240}$. Ahora remito los dos tomos del Salengre; y por más diligencias que he practicado no he podido hallar les sentiments de Clearque, ni las dos piezas sobre la Tragedia de Mahomed; pero estaré a la mira por si en adelante puedo dar con ellas.

He leido ya en los papeles periódicos hasta quatro impuganciones de Necker; pero como no las he visto, ni oido hablar de su mérito no me he resuelto a embiarlas.

El precio de los libros que he embiado importa 27 libras, en la forma siguiente. La Historia del Concilio de Basilea 12; los tres tomos sobre granos a tres cada uno 9; y seis el Salengre.(...) He examinado con mucho cuidado varios catálogos que tengo de librerias famosas de aquí, y la Bibliographia de Mr. de Bure ${ }^{241}$. que trahe todo lo raro que ay en esta Corte, por ver si podía hallar los libros que V.E. tiene y pudo lograr en Roma; pero me he desengañado de que no los conocen aquí; por lo que estimaré a V.E. que me embie una descripción tipográphica bien circunstanciada de cada uno de ellos, y de su historia, para poder consultar con ella a Mr. de Bure, cuya Bibliographia se estima aquí mucho» ${ }^{242}$.

238. MENAGE o Aegidii Menagii (1613-1692). Autor del Dictionnaire etymologique..., (Paris, 16501670), más conocido por Origenes de la langue française... Entre otras de sus obras: Iuris civilis Amoenitates, Francofurti et Lipsiaa: impeusis Hered. Frederiü Lanckisii: typis Christophori Guntheri, 1680; en Nápoles, Vicentium Orsino, 1779. Ibíd. Poemata, Amsterdam, H. Wetstenium, 1687: Ibíd. Anti-Baillet ou Critique du livre de Mr. Baillet... / par Mr. Menage, Amsterdam, 1725 . Historia miluerum philosopharum / scriptore Aegidio Menagio; accedit eius deu Commentarius Italianis en VII. Sonettum Francisci Petrauva, à re nos alienu Lugduni. Apud Anissonias, Joan Posuel \& Caludium Rigaud, 1690: Ibíd. In Diogenem Laertium Aegiddi Menagii Observationes \& emendationes hac editione punnum auctae...; accedunt Joachini in Diogenen Laertiumm Observationes..., Amstelaedami, Apud. Henricum Wetstenium, 1692. Le origini dellla lingua italiana, compilata dal Ser. Egidio Menagio..., colla quiunta de modi di dire italiani, Maccolti e dichiarate dal medesimo. Geneva, Apresso Giovanni Antonio Chovet, 1685.

239. [Heredia - Roda], París, 30 de junio de 1775.

240. La obra de Ferdinado GALIANI Dialogues sur le commerce des blés, Paris, 1764, fue publicada en España como Dialogos sobre el comercio de trigo / atribuidos al abate Galiani ... ; traducidos del Francés, Madrid, por D. Joaquin Ibarra, 1775.

241. BURE, Guillaume-François de. Bibliographie instructive ou traité de la connaissance des livres rares et singuliers, Paris, G.F. De Bure jeune, 1763-1768, 7 vols, in $8^{\circ}$. Otra edición, París, 1775.

242. [Heredia - Roda], París, 10 de julio de 1775. 
Heredia iba dando cuenta periódica de la novedades editoriales. En septiembre le informaba de haberse concluido La Historia de la Reyna Christina ${ }^{243}$, publicada en cuatro tomos en $4^{\circ}$, pero no había podido averiguar todavía «que obra puede ser la otra que V.E. empezó a ver en Roma, que trata de libros raros poniendo los authores por orden alphabético, pero no olbidaré la especie y lo abisaré a V.E. en caso de apresarlo» 244 , como efectivamente hizo en agosto de 1775: "Con fecha de 17 escribí a V.E.; por lo que sólo diré aora que la obra Bibliographica que V.E. empezó a ver en Roma será sin duda la Biblioteque curieuse des libres rares de David Clement ${ }^{245}$ impresa en Hamburgo, a la qual combienen las circunstancias que V.E. me indica en su carta. Esta obra tiene nueve volúmenes en quarto, pero haviendo muerto su author quedó imperfecta y no parece que haya apariencia de que se concluya. Su precio son 90 libras, y no la compraré hasta que V.E. me lo abise, porque dudo que V.E. la quiera con lo que llebo dicho» ${ }^{246}$

Entre las últimas obras que Roda le había solicitado en el verano de 1775 estaba el Botanicum Parisiense, de Bayan [Vaillant], que no había podido encontrar, si bien un librero le había dicho haber vendido recientemente un ejemplar por 36 libras ${ }^{247}$.

Tras pasar una larga temporada en Versailles con motivo de la boda entre la princesa Clotilde -a quien Aranda consideraba «extremadamente gruesa»- y el entonces Príncipe de Piamonte, y futuro Victor Manuel IV de Saboya, escribía Heredia respecto a un voluminoso encargo de Roda: «La Bibliotheca maxima Patrum impresa en León, studio Philippi Despont, que con el Index impreso en Génova, y el Aparato de Nourry, compone treinta volúmenes, es obra bastante rara, y que según me han informado dos libreros, hace algunos años no se ha bendido ningún exemplar en las almonedas, por lo que creen que el primero que se presente pasará de mil y quinientas libras. De esta misma Bibliotheca ay dos ediciones de la Bigne; una de Colonia que se bende a los especieros, y otra de París que tiene alguna más estimación, y con los suplementos de Combefis ${ }^{248}$ se hallará por cien libras poco más o menos. Los to-

243. ARCKENHOLTZ, Johan, (1695-1777) Memoires concernant Christine reine de Suede, pour servir d'eclaircissement a l'histoire de son regne et principalement de sa vie privée, et aux evenemens de l'histoire de son tems civile et litèraire: suivis de deux ouvrages de cette savante princesse, qui n'ont jamais étè imprimés. A Amsterdam et a Leipzig. Chez Pierre Mortier, 1751-1760. 4 vols.

244. [Heredia - Roda], Sin fecha. [17 de septiembre 1775]: «cuyo precio en sus principios era de 60 libras, pero después ha baxado a quarenta. Si V.E. la quiere y no corre prisa se podía aguardar a ver si sale en alguna almoneda, que aún se logrará más barata».

245. CLEMENT, David (1710-1760). Bibliotheque curieuse historique et critique, ou Catalogue raisonné de livres difficiles a trouver / par David Clement; 9 vols, Gotinga, 1751-1760. Clement editó el Specimen bibliothecae hispanico majansianae, sive idea catalogi critici operum scriptorum hispanorum quae habet in sua blibliotheca $G$. Majansius. Hannover, 1753.

246. [Heredia - Roda], París, 20 de agosto de 1775.

247. [Heredia - Roda], París, 20 de agosto de 1775. Sebastián VAILLANT (1669-1722). Discípulo de Tournefort, ingresó en la Academia de Ciencias de París en 1716 y fue Director del Jardín Real de Plantas de París. Su Botanicon Parisiense fue publicado por Boerhaave en Amsterdam-Leyden en 1727.

248. COMBEFIS, François (O.P.) (1605-1679) Bibliotheca Patrum concionatoria : hoc est anni totius evangelia, festa dominica, sanctissimae de iparae, illustriorumque sanctorum solennia ... / opera et 
mos de Nourry, especialmente el primero, es [sic] muy raro, y se benden los dos por 250 libras. Un librero de aquí que acaba de benir de Madrid me ha dicho que havía visto dos juegos de la edición de León en la tienda de Alberá, por lo que puede ser que ahí se compre más barata que aquí, como sucede con otras muchas obras, por ser muy ignorantes esos libreros en comparación de estos ${ }^{249}$.

Las obras de Thiers tienen bastante estimación, y la más cara es la que ya tiene V.E. de las pelucas que acostumbra a benderse en las almonedas entre seis y ocho libras. Las otras se bendieron en la primabera pasada a tres y quatro libras por tomo.

Langlet [Lenglet] du Fresno $\mathrm{i}^{250}$ tiene un número inmenso de obras propias, y de agenas que publicó con notas y observaciones propias, como puede V.E. verlo en Moreri ${ }^{251}$, lo que me hace dudar de que V.E. las quiera todas; por lo que aguardaré a que V.E. me diga lo que piensa sobre este particular, y sólo compraré, si antes se presenta ocasión, el méthodo para estudiar la historia, y alguna otra.

No se si V.E. tiene la historia natural de Buffon de cuyos 15 tomos en $4\left[^{\circ}\right]^{252}$ me hizo pagar ahí Copin 300 pesetas, y 21 de cada uno de las historia de los páxaros,

studio F. Francisci Combefis, Ordinis FF. Praedicatorum Congregationis Sancti Ludovici ... ; Editio Veneta, auctior, \& emendatior ... \& in duodecim tomos distributa, Venetiis : ex typographia Caroli Pecora, 1749.

249. Maxima bibliotheca veterum Patrum et antiquorum Scriptorum ecclesiasticorum / primò quidem à Margarino de la Bigne... in lucem edita ; deinde celeberrimorum in Vniuersitate Coloniensi doctorum, studio, plurimis authoribus et opusculis aucta, ac historicá methodo per singula saecula quibus Scriptores quique vixerunt disposita ; tomus primus continens tres ex quatuor supra laudatis indicibus... ; Hac tandem editione Lugdunensi ad eandem Coloniensem exacta, novis supra centum authoribus \& opusculis hactenus desideratis locupletata et in tomos XXVII distributa, huic etiam editioni accesserunt indices quatuor... ; Lugduni : apud Anissonios, 1677. Edición de P. Despont. Nicolás Nourry (1647-1724), benedictino de Saint Maur, fue biógrafo y editor de las obras de Casiodoro junto con el P. Garet, colaborador en la edición de las obras de San Ambrosio con los PP. Duchesne y Belasio. Editor también de San Gregorio Naciaceno fue colabaorador destacado de la Colección Máxima de Lyon. Fue el autor de Apparatus ad Bibliothecam Patrum.

250. LENGLET DUFRESNOY, Nicolás (1674-1755). Polígrafo francés con una prolija obra de temas históricos, teológicos, de química y, finalmente, de ocultismo. Además de Sobre el secreto inviolable de la confesión (1708) publicó Méthode pour étudier l'histoire (1713) y Méthode pour étudier la geographie (1716) unas Tablas cronológicas de la Historia Universal (1729). Una Historia de Juana de Arco (1753). Entre sus obras erudito-esotéricas destaca la Histoire de la philosophie hermétique (1742), el Traité historique et dogmatique sur les apparitios (1751) y diversas obras sobre química, incluida la traducción de la Metalurgia de Alonso Barba (1751).

251. MORERI, Luis (1643-1680) Le grand dictionnaire historique ó melange curieux de l'histoire sacrée et profane, Lyon, 1674, Amsterdam, 1694. La vigésima edición, en 10 vols, impresa en 1759 es considerada la mejor, con los Suplementos de Gaojet y Drouet. La traducición española, de José de Miravel y Casadevante, «con amplísimas adiciones... investigaciones relativas a los Reyos pertenencientes a las coronas de España y Portugal» data de 1753, París y León de Francia, por los Hermanos Tournes.

252. BUFFON, George Louis Leclerc, Comte de. Histoire naturelle générale et particulière avec la description du Cabinet du Roy, Paris, de l'Imprimerie Royale, 15 tomos, 1749-1767, Histoire naturelle, générale et particuliere servant de suite à la thèorie de la Terre... ... / par M. le Comte de Buffon ... ; A Paris,de L'impremerie Royale, 1774-1778; Manuel du naturaliste: ouvrage utile aux voyageurs... I par M. de Buffon...; A Paris : de l'Imprimerie Royale, 1771, 2 vols.; Histoire naturelle des 
por cuya cuenta los 20 tomos que hasta aquí ay publicados suben a 405 pesetas. Si V.E. no lo tiene y la quiere creo poder lograrla por 220 o 30[0] libras comprando en almoneda una parte de la obra y tomando del librero los tomos que falten los quales se benden a 15 y 17 pesetas cada uno.

Como creo que V.E. no necesita al pronto de ninguno de los libros que me pide aguardaré a ver si puedo comprarlos en almonedas, las quales son más frecuentes en invierno y primavera que en el verano, a causa de que en este tiempo se van las mas de las gentes a la campaña; y de los que aya ocasión los tomaré de los libreros» ${ }^{253}$.

El 11 de noviembre, próxima ya a finalizar la jornada de Fontainebleau, anunciaba al Ministro su inminente regreso a la capital, dispuesto a reanudar sus aventuras bibliográficas: «Pasado mañana nos restituimos a París, y procuraré aprobechar las ocasiones que se presenten para ir comprando los libros que V.E. me ha pedido, y los que V.E. me dice me abisará» ${ }^{254}$.

Mediado el mes de diciembre Heredia daba puntual de su actividad como bibliófilo: «Luego que me restituí de Fontainebleau vino a verme el librero Fournier y me dixo que le havían pedido para V.E. la colección de las gacetas eclesiásticas, y que las tenía dispuestas para remitirlas en la primera ocasión que ocurriera. Yo le dixe que lo suspendiera hasta ver si yo podía comprar algunos libros que V.E. me tenía encargados y formar un balote; y para que no le causara perjuicio el retardo le pagué de cuenta de V.E. el importe de las gacetas.

En todo el tiempo que ha pasado desde entonces no ha havido almoneda de probecho, y sólo he comprado de libreros las Memorias de la Reyna Christina; el Botanicon parisiens; las Apariciones de Langlet, y las más de las obras de Thiers, las que todavía no bastan para llenar un fardo.

Las obras de Thiers son muchas más de las que yo conocía; y haviendo comprado de Mr. de Bure 31 tomos en $12\left[^{\circ}\right]$ aún faltan algunos para su complemento. Me resolbí a comprarlos porque vi que para poderlos recoger en almonedas era necesario aguardar tal vez años; y porque en los precios de las obras que yo havia visto bender el año pasado no hallaba diferencia notable. Los más raros de los que he comprado, y por lo mismo los más caros, son tres quadernillos pequeños intitulados la Sauce Robert que ha costado 15 libras; Inscription du Portaill des Cordelliers de Reims 12 libras y de retinenda voce Paraclitus. Pero la obra rarísima de Thiers, y que me dixo de Bure que no la havía tenido sino una vez, es Observations sur le nouveau Breviaire de Cluni, 2 tomos. La tiene un librero que no quiere darla menos de 48 libras y no me he resuelto a comprarla hasta que V.E. me lo diga. Entre los tomos

oiseaux...: [ par M. de Buffon] A Paris: de l'Imprimerie Royale, 6 vols, 1770-1779. Los 15 tomos de la Historia natural, general y particular / escrita en francés por el conde de Buffon luego traducidos por D. Joseph Clavijo y Faxardo, y publicados por Ibarra en 1785.

253. [Heredia - Roda], París, 25 de se[p]tiembre de 1775. Heredia compró en París. de acuerdo con el inventario de Olaechea cuatro tomos de los quince de que se componía la Histoire naturelle générale et particulière, París, 1749-1767.

254. [Heredia - Roda], Fontainebleau, 11 de noviembre de 1775. 
que compré, y no quiso descartarlos de Bure, están el tratado de las Pelucas y las lagrimas de Bandoma [sic]. El primero me lo quedaré yo. El segundo está enquadernado con la respuesta del Padre Mabillon, y la replica de Thiers, por lo que si V.E. tiene todo esto y me lo abisa a tiempo tampoco lo embiaré.

Es regular que a V.E. le falten algunos quadernos de las Artes y oficios, por lo que incluyo la lista de los que hasta aora ay publicados, para que pueda abisármelo y comprárselos» 255 .

El gusto de Roda por las obras de Thiers parece proceder no sólo de la magnitud de la obra del prolífico erudito de Chartres, sino también de cierto sentimiento de simpatía por un hombre de procedencia humilde, que a pesar de no haber obtenido mayores dignidades que la de un modesto curato se evidenció como un investigador infatigable, con un agudo sentido crítico, «peut-être trop caustique», según se apostillaba en el artículo correspondiente del Dictionaire de Théologie Catholique.

En la última ocasión Roda le debió hacer un importante encargo de libros, cuyos rasgos generales sólo conocemos por las respuestas de Heredia. El 10 de febrero avisaba al Ministro de haber adquirido «los nueve tomos de David Clemente de un librero, porque no se ha vendido esta obra completa en ninguna almoneda desde que V.E. me la pidió. Sólo en una havía cinco tomos, y me dixeron que no la podría completar en Paris, y que sería preciso acudir a Alemania por los restantes. También he comprado las Obserbaciones sobre el Breviario de Cluni de Thiers, y los quadernos de Artes que V.E. me dice le faltan (...) Con estas obras nuevamente compradas ay ya para hacer un balote, y he prevenido a Fournier que luego que esté enquadernada la obra de David Clement, que compré en papel, forme el balote y lo embíe a Bilbao a su corresponsal, dirigido a nombre de V.E. Quando lo haya exequtado lo abisaré a V.E., y acompañaré la lista de los libros y su coste» ${ }^{256}$.

Fournier envió el balote de libros a Bilbao por la ruta de Ruán, facturados a su corresponsal Goicoechea, para que los hiciese llegar a Roda. El 4 de marzo Heredia informaba haber hecho suscribir en el puerto francés un seguro de 500 libras, por apenas 11 sueldos. Heredia, que además de los libros había adelantado también a Fournier el importe de la suscripción de Roda a la Gaceta Eclesiástica, le remitía una factura de 647 libras y 17 sueldos para que «quando V.E. guste» se la pagase a José Prior.

Para completar las obras de Thiers quedaban todavía pendientes de comprar «...el Traité de l'absolution de l'heresie; otro sur les Porches des Eglisses; Factum pour les Curés de Pinserais. Oraison funebre de Mr. de Fhou y Lettres sur la regle de Sn. Benoit. Los dos primeros son comunes; los otros no creo que merezcan mucho aprecio, pero estaré a la mira para comprarlos si se presenta la ocasión, y he dado la nota a Fournier para lo mismo. Igualmente lo practicaré con las obras de Lenglet, y de Buffon, aguardando para las de este último, que se bendan en alguna almoneda, por cuyo medio se tendrán más baratas» ${ }^{257}$.

255. [Heredia - Roda], París, 12 de diciembre de 1775.

256. [Heredia - Roda], París, 10 de febrero de 1776.

257. [Heredia - Roda], París, 4 de marzo de 1776. 
A mediados de marzo del 76 Roda volvió a enviar a Heredia una nueva lista de libros: «Luego que recibí la carta de V.E. de 11 de marzo -escribía Heredia-empecé a practicar las diligencias para comprar los libros que V.E. me pide, y en el día los tengo ya todos a excepción del Psalterio de Salomón del Padre Scoto, de quien nadie me sabe dar razón, ni yo he podido hallar indicada esta obra en Moreri, ni en ninguno de los catálogos de librerías que tengo, por lo que combendrá que V.E. me de sus señas individuales para ver si por ellas se puede benir en su conocimiento.

El Basilicon de Fabroto ${ }^{258}$ he tenido la fortuna de comprarlo en una almoneda por 80 libras a causa de que en dos o tres tomos ay algunas ojas que están roidas de los gusanos en las márgenes, lo que para estas gentes es un gran defecto. Pasado pasqua le embiaré a V.E. estos libros dirigidos a Alfonso la Higuera; y porque es pequeño le incluyo a V.E. aora el Amusement sur le langage des betes ${ }^{259}$. Acompaño también la lista de los libros y sus precios.

No se si V.E. tiene la Historia universal de una sociedad de gentes de letras de que ay publicados 36 tomos en $4\left[^{\circ}\right]$. Yo la he comprado para mí en 360 libras, cuyo precio poco más o menos es el que tiene en las almonedas. Si V.E. la quiere podrá avisármelo, pues se bende en ellas con bastante frecuencia.

Remito a V.E. el catálogo que ha publicado Pankuk [sic] de algunas obras que ha puesto al "rebais" hasta el mes de se[p]tiembre, por si halla V.E. alguna que le guste. Yo he comprado la colección académica del artículo 4 porque es obra interesante; si V.E. la quiere podrá decirme si la he de hacer enquadernar o embiarla en papel, que es como la bende al precio que expresa el catálogo» 260 .

Las peticiones de Roda se hacían cada vez más frecuentes. Heredia dedicó íntegramente una carta fechada el 26 de abril a dar cuenta del estado en que se hallaban los últimos encargos del Minstro: «Luego que recibi la de V.E. de 8 del corriente di el encargo a Fournier para que me buscara el Breve de Benedicto X4 [sic] valiéndose para ello de los colporteurs de la gaceta eclesiástica y de un librero jansenista; $y$ después de exquisitas diligencias sólo se han podido hallar esos tres exemplares que remito, haviéndome desauciado enteramente de poderme encontrar otros.

Entre las obras de Thiers que he remitido ay una que se intitula Disertationis ecclesiatiques, en la que están los tratados sobre les Ausels des Eglises, des Jubes etc., que V.E. hecha [de] menos; y creo que en la sance [sic] Robert está también la segunda pieza de la justificación. De las otras obras del mismo author que tengo encargadas no ha [a]parecido aún ninguna.

Los libros que dixe a V.E. en mi última remitiría a Alfonso la Higuera para V.E. salieron de aquí la semana pasada para Ruán, de donde no ay noticia de que se ha-

258. Se refiere al cardenal Carlo Annibale FABROTTO (1580-1659) Ton basilikon biblia XI. Basilikon libri $L X$ in VII tomos divisi. Parisiis, Sumptibus Sebastiani Cramoisny ...et Gabrielis Chamoisy, MDCXLVII, 7 tomos in fol, con los textos griego y latino.

259. Amusement philosophique sur le langage des bestes Troisiéme edition / augmentée de la lettre de l'auteur \& de la critique. (A Paris: chez. Gissey...: [chez] Bordelet...: [chez] Ganeau..., 1740).

260. [Heredia - Roda], s.l. s.f. (H. finales de marzo-abril-mayo de) [1776]. 
yan embarcado aún. Por lo que toca a cuentas puede V.E. estar sin cuidado, pues es cierta la respuesta que dió Prior de que nada se debía.

No tengo tiempo para más. Acá todos estamos buenos, y se repite a las órdenes de V.E. su mayor servidon ${ }^{261}$.

En el mes de junio -tras haber quedado brevemente interrumpida la correspondencia por un «inopinado viage a Marly»-escribía Heredia ya desde París: «El lunes de esta semana debía haverse empezado la venta de una librería, [la de Monsieur Le Marié] que no se ha verificado por haver mandado la Justicia que se suspendiera a instancia de uno de los herederos. Dos dias después me dixo el librero Debure, que debe hacer dicha venta, que se havía quitado el embarazo, y que se empezaría el 26 de éste; pero últimamente me ha buelto a decir que havían nacido nuevas dificultades y que no sabía quando podría hacerse. En esta incertidumbre me he resuelto a remitir a V.E. el catálogo por si halla en él algunos artículos que le combengan, en cuyo caso no tiene V.E. que hacer otra cosa que expresar los números de los que quiere, y embiármelos sin pérdida de tiempo. Repare V.E. en el $n^{\circ} 381$ [sic]. He preguntado a Debure si tenía algún exemplar, y me ha dicho que nunca ha tenido otro que el que expresa en catálogo, y que ya tenía orden para comprarlo, lo que me hacer ver que nos lo harán pagar caro. Generalmente se prevee que todos los libros de esta librería van a benderse a un precio muy subido por las circunstancias que expresa la advertencia que está al principio. Sólo el bender Debure una librería basta para darle crédito, y con este conocimiento dispuso el dueño de ésta en su testamento que la hiciera él, y no conformándose los herederos mandó que le dieran tres mil libras.

No creo que al recibo de ésta se halle ya ahí Don Francisco Bayer, pues me escribe en este correo que iba a partir para Valencia. Si por alguna casualidad estuviera aún ahí, puede V.E. dexarle ver el catálogo para que escoja los libros que necesite; y en caso de que haya partido, ruego a V.E. le mande dirigir esta carta. No tengo lugar para más, y se repite a las órdenes de V.E. su mayor serbidor y amigo» ${ }^{262}$.

El 5 de julio de 1776 Heredia comunicaba a su paisano que acababa de remitirle «el primer tomo de las cartas de Ganganeli ${ }^{263}$, y en los correos succesivos irá el segundo, y la Pastoral contra los Incrédulos del Arzobispo de León, que es la única que yo he visto, y me ha traido el librero, a quien he prebenido que vea si ay otra. El Monarca accompli no vale la pena de dar por él lo que hacen pagar, pues las prohibiciones que se hacen acá de los libros no tienen otro efecto que el de duplicar el precio de los libros a favor de los libreros.

261. [Heredia - Roda], París, 26 de abril de 1776.

262. [Heredia - Roda], París, 21 de junio de 1776.

263. CLEMENTE XIV. Lettres intéressantes du Pape Clément XIV (Ganganelli, A Paris, chez Lottin, 1776. Nipho tradujo al castellano las Cartas importantes del Papa Clemente XIV... / Coleccion formada por el marques Caracciolo ; traducidas de francés en castellano por Francisco Mariano Nipho, 2 vols. Madrid, 1777. Caraccioli, Louis Antoine de, Marquis (1721-1803) La vie du pape Clément XIV (Ganganelli) / par M. Caraccioli. A Paris : chez la vetuve Desaint..., 1776. 
Desde que se publicaron las cartas de Ganganeli las crei supuestas, y esta misma idea formaron aquí muchos. Caraccioli, que es el editor, quiso sostener su autenticidad en el impreso que acompaño; pero como sé cierto que el librero le dió tres mil libras por original, dudo de la verdad de quanto dice. V.E. que conoce bien al difunto Papa podrá juzgar mejor que nadie si son verdaderas o supuestas.

No hablo a V.E. del precio de los libros que aora remito porque no lo sé aún, y porque lo incluiré quando embie otros.

Creo que havrá sobra de tiempo para que V.E. pueda examinar despacio y avisarme los libros que quiera del catálogo que le embié de la librería de Mr. Lemarié, porque, según me dixo de Bure, puede ser que pasen meses antes que se haga la venta, por los enredos que cada día suscita uno de los herederos» ${ }^{264}$.

Las almonedas de las bibliotecas importantes, y tanto más si se trataba de las subastadas por Bure, se convertían en una auténtica fiesta para Heredia. Solucionados los enredos de la herencia, por fin pudo ponerse a la venta a principios de agosto: «Aunque recibí la de V.E. el día antes que partió el correo extraordinario no tuve cabeza ni tiempo para escribir a V.E. por él, ni tampoco Cornel que salió un día después.

Aora puedo decir a V.E. que justamente me llegó su carta quando ya se havian fixado los carteles para la venta de la librería de Lemarie, que empezó el lunes de esta semana. He concurrido a ella los tres días que van pasados, y veo verificado lo que havia anunciado a V.E. de que se benderían carísismos los libros. El Aleninsui Thesaurus linguarum orientalium, que me dixo de Bure se lo havia bendido en 300 [libras] se remató en 900. Los viages de Bey en 1.760, y todo va a este tenor. Ayer le compré a V.E. tres artículos. El primero si la Torture est un moien ${ }^{265}$ etc., que es un librillo muy pequeño, y que aparece de él mismo que costó 30 sueldos, me lo pujaron hasta 9 libras 19 sueldos, y quedó por mi un sueldo más que son 10 libras. El segundo que es Andus Poza ${ }^{266}, 12$ libras, y me dixo de Bure que le havía hecho pagar 18; el tercero Limboren ${ }^{267}$ historia de la Inquisición fue barato en 20 , pues los libreros lo venden de 26 a 30.

264. [Heredia - Roda], París, 5 de julio de 1776.

265. NICOLÁS, Augustin, (1622-1695). Si la torture est un moyen seur a verifier les crimes secrets; dissertation morale et juridique, par laquelle il est amplement traitté des abus qui se commettent par tour en l'instruction des procés criminels, \& particulierement en la recherche du sortilege. Ouvrage necessaire à tous juges, tant souverains que subalternes, \&. Amsterdam, A. Wolfgang, 1681

266. POZA, Andres de. De la antigua lengua poblaciones y comarcas de las Españas : en que de paso se tocan algunas cosas de la Cantabria / compuesto por ... Andres de Poça, Impresso en Bilbao : por Mathias Mares, 1587.

267. LIMBORCH, Felipe van (1633-1712) Teólogo holandés formado en la Universitad de Utrecht y defensor de las doctrinas arminianas. Fue pastor en Genda desde 1657 y en Amsterdam desde 1667. Entre sus obras destacan las Institutiones theologiea christianae, ad praxis pietatis et promotionem pacis christianae unice directae, Amsterdam 1686, considerada una de las mejores fuentes del arminianismo; De veritate religionis christianae amica collatio cum erudito Iudaeo, Genda, 1687, Commentarios in Acta Apostolorum et in epistolas ad Romanos et ad Hebraeos, Roterdam, 1711, y la aludida aquí por Heredia, Historia inquisitionis, cui subjungitur Liber sententiarum inquisitionis Tholosanae ab anno Christi CICCCCVII ad annum CICCCCXXIII..., Amstelodami, Apud H. Wetstenium, 1692. 
El primer día se vendió el suplemento del Basilicon de Fabroto, pero no pude comprarlo porque lo bendieron con la obra principal, que se remató en 182 libras. Pregunté a algunos libreros conocidos míos que havía allí si lo tenían y me dixeron que no; pero es seguro que se halla siendo tan moderna la impresión.

El Hipócrates de Vander Linden es el mejor de todos, y su verdadera data la del año 1665 que se expresa en el catálogo. Es libro algo raro y seguramente havrá muchos golosos que nos lo harán pagar caro; pero no debe perderse la ocasión de comprarlo, porque todos estos libros clásicos suben de precio cada día, de modo que si alguno huviera comprado toda la librería de Lemarie y la guardara diez años, podía estar seguro de duplicar el precio. ${ }^{268}$

En días pasados le compré a V.E. la obra de Buffon en 20 volúmenes en $44^{\circ} \mathrm{J}$ por 240 libras, 70 libras más barata de lo que la benden los libreros, y 151 de lo que me ha costado la mía, pues de los 17 tomos me hizo pagar ahí Copin 340, y los tres que he comprado acá me han costado a 17 cada uno» ${ }^{269}$.

La venta de la librería se prolongó hasta el día 2 de septiembre, y Roda pudo darse por satisfecho del celo desplegado por Heredia. De los 29 títulos por los que Roda había demostrado interés, el secretario de Aranda pudo adquirir 22 a precios razonables, mientras que los restantes alcanzaron precios que Heredia consideró exorbitantes. Un ejemplar del Romancero general, que salío a subasta con un precio de 15 pesetas, fue finalmente adjudicado por 72 pesetas. Heredia detallaba a Roda que «igual lance con el Diálogo de la Lycantrophie; con el Alphabeti naturalis Hebraici delineato ${ }^{270} ; y$ con el Homerus Hebrairans, porque los que los compraron estaban resueltos a logralos a qualquier costo; pero se los dexé quando vi que excedían considerablemente de su valor. No fue poca fortuna el no haver tropezado con algún loco semejante en el de la Boca sin lengua, y con todo costó 13 libras 14 sueldos. El más barato de todos los que he comprado para V.E. es el Hipócrates en 36 pesetas. Tampoco se compraron por muy caros el Limborch de veritate religionis; y el Vergier [Bergier] histoire des grans chemins ${ }^{271}$; pero los he adquirido de los libreros por 18 libras menos. El Suplemento del Basilicon no se halla acá; veré si puedo hacerlo benir de Holanda.

268. LINDEN, Joannes Antonides van der, ed. lit. Magni Hippocratis coi Opera Omnia: Graece \& Latine edita et ad omnes alias editiones accommodata / industria [et] diligentia Joan. Antonidae vandes Linden... Lugduni Batavorum : apud Danielem, Abrahamum \& Adrianum à Gaasbeeck, 1665.

269. [Heredia - Roda], París, 16 de agosto de 1776.

270. HELMONT, François-Mercure van. Alphabeti vere naturalis hebraici brevissima delineato: quoe simul methodum suppeditat juxta quam qui surdi nati sunt, sic informari possunt, ut nos alios saltem loquentes intelligant, sed \& ipsi ad sermonis usum preveniant in lucem deita a F.M.B ab Helmont, Sulzbaci, typis Abrahami Lichtenthaleri, 1657 [1667].

271. BERGIER, Nicolás. Histoire des grans chemins de l'Empire Romain: contenat l'origine, progrès \& etendué quasi incroyable des chemins militaires, pavez depuis la ville de Rome jusques aux extremites de son empire ...Bruxelles: chez Jean Leonard..., 1736, Histoire des grands chemins de l'Empir romain: Contenant l'origine, progrés \& estendu e des chemins militaires panez drepuis la ville de Rome insques aux extremitez de son Empire ou se voit.. l'esclarcissement de l'itineraire d'Antonin et de la Carte de Pentinger/par Nicolas Bergier, Paris : chez C. Morel..., 1622. 
Si el correo no se va muy cargado le embiaré a V.E. con él todos los libros pequeños; y los otros saldrán de acá regularmente en este mes, de los que abisaré entonces» ${ }^{272}$. Efectivamente, a principios de enero de 1777 Heredia le avisaba tener ya en su poder el suplemento del Basilicon que le acababa de llegar, y que había vuelto a contratar con Fournier la suscripción a la Gaceta Eclesiástica ${ }^{273}$.

En octubre había organizado Heredia la remisión por Ruán de los balotes de libros que había adquirido por encargo de Roda y de Pérez Bayer, aunque después había podido encontrar «hallar la refutación de Espinosa ${ }^{274}$, que es todavia peor que sus obras, y el viage de Benjamin ${ }^{275} ; y$ he hecho pedir a Holanda el suplemento del Basilicon de Fabroto» ${ }^{276}$.

No obstante, los encargos de Roda seguían llegando, hasta el punto que Heredia, ya de jornada en Fontainebleau, hubo de solicitarle un compás de espera para poder cumplimentarlos: «Como recibí la carta de V.E. que bino por el extraordinario en este sitio, sólo puedo decir a los encargos de libros que V.E. me hace, que procuraré desempeñarlos en llegando a París, a donde es regular nos restituyamos del 12 al 13 del corriente» ${ }^{277}$.

Después de la pascua de Navidad, y al tiempo que se hacía eco del ruido causado por el encarcelamiento de Olavide, retomaba el negocio de los encargos de Roda y las principales novedades literarias de París: «Voy a satisfacer a V.E. los diferentes puntos de librería que tenemos pendientes, y empiezo por decir a V.E. que se me ha perdido la última lista que me embió, en que me acuerdo me pedia V.E. los quadernos de Artes y Oficios de la Academia que le faltan, y algunas obras de T[h]iers. Puede V.E. bolvérmela a embiar, y para que sepa con seguridad lo que le falta de Artes y Oficios. Incluyo el catálogo de los que hasta aora se han publicado.

No creía yo que la ausencia de Bayer fuera tan larga como V.E. me dice; ni tampoco sabía que embiaba los libros a Valencia, en cuyo caso debiera haverme prebenido que se los dirigiera por Marsella en lo que huviera aorrado de portes. A esto se añade el que pensando que Prior estaria en Madrid en en mes de octubre, le incluí en su pliego la carta en que abisaba a Bayer la remesa, y los que eran para V.E., cuyo pliego, que dirigí a [Casimiro] Ortega para que lo entregara a Prior, no sé quando lo haya recibido, por ignorar si ha llegado aún a esa villa. En todo caso, puedo

272. [Heredia - Roda], [París, septiembre] de 1776. «La semana pasada embié a Ruán unos balotes de libros para Don Francisco Bayer...» [Heredia - Roda], Fontainebleau, 9 de noviembre de 1776.

273. [Heredia - Roda], París, 13 de enero de 1777.

274. FÉNELON, François de Salignac de La Mothe (1651-1715.): Rèfutation des erreurs de Benoit Spinosa, par M. de Fenelon, le P. Lami, et par M. le comte de Boullainvillers. Avec la vie de Spinosa, escrite par Jean Colerus...augm. de beaucoup de particularités tirèes d'une vie manuscrite de ce philosophe, faite par un de ses amis. Bruxelles, F. Foppens, 1731.

275. BENJAMIN DE TUDELA Ybrlstw'sm zytynb / Itinerarium D. Beniaminis / cum versione \& notis Constantini l'Empereur ab Oppyck... Lugd. Batavorum : ex Officiná Elzeviriana, 1633.

276. [Heredia - Roda], París, 10 de octubre de 1776.

277. [Heredia - Roda], Fontainebleau, 9 de noviembre de 1776. 
decir a V.E. que todos sus libros van en el balote número 7 marcado P.B.R., y que quando lleguen ahí, que será en breve según el tiempo que hace salieron de Ruán, puede V.E. hacer que se desaga dicho fardo, y recogerlos» ${ }^{278}$.

Los encargos para la compra de libros alternan con las noticias acerca de las novedades editoriales en París. Roda había mostrado interés por la persona y obra del joven Anse de Villoison ${ }^{27}$, personaje al que Heredia había conocido poco después de su llegada a Francia: «Conozco mucho al sugeto de quien havía hablado a V.E. el Duque de Alba, pues con motivo de ser descendiente de un español bino a verme a los principios de mi arribo, y después lo ha repetido algunas veces. Su abuelo o bisabuelo, que bino a Francia con la reina Ana de Austria se llamaba Anso, y sus descendientes acomodando el apellido al carácter de esta lengua lo han combertido en Anse de Viloison. Si V.E. quiere saber más particularidades de él puede preguntar a Ortega que lo trató mucho. Hasta aquí no ha publicado más que el Apol[1]onio sophista sacado de un manuscrito de la Abadía de San Germán. Trabaja actualmente en dos autores griegos, que el uno es Musco, y el otro no me acuerdo; y en el manuscrito de la Emperatriz Eudoxia; pero tardará aún mucho en publicar este último» ${ }^{280}$.

El 6 de febrero de 1777 escribía: «Compraré el Apollonio de Anse de Villoison (que acaba de hacerme saber por un papel que se ha casado) y lo remitiré quando V.E. me diga los quadernos que le faltan de Artes y Oficios. Ya me havía abisado Prior el recibo del importe de los últimos libros» ${ }^{281}$.

Pero, además de su labor de paciente «colporteur» para sus amigos -Roda, Pérez Bayer, Vicente Blasco, Higuera, Iriarte, Eugenio Llaguno, etc.- de Madrid, Heredia se permitía también el gusto de sorprender ocasionalmente a su corresponsal procurándole algunas obras clandestinas. El 22 de marzo le avisaba de incluirle «una carta de Linget al Conde de Vergennes, que es rarísima acá por las grandes precauciones que ha tomado el Govierno para impedir su curso. Por ella verá V.E. que en todas partes están expuestos los Ministros a la censura de los insolentes; y este es uno de los de primer orden que se conocen en Europa» ${ }^{282}$

278. [Heredia - Roda], [s.l.] [s.f./ finales de diciembre de 1776, primeros de enero de 1777]. Pérez Bayer hizo donación de su «numerosa i preciosísima librería» a la Universidad de Valencia en 1775. Su correspondencia al respecto con Juan Antonio Mayans en Gregorio Mayans y Siscar. Epistolario VI. Mayans y Pérez Bayer, Valencia, 1977.

279. ANSSE DE VILLOISON, Jean Baptiste Gaspar de (Corebeil, 1750-París, 1805) Formado en el Colegio de Francia, a los 22 años publicó Léxique d'Apollonius sur Homére (1772) Miembro de la Academía de Inscripciones parisiense. Entre las obras que publicó cuando Roda todavía estaba con vida destaca Daphnis et Cloe, en edición greco-latina con comentarios (1778), antes de ser enviado a Venencia para registrar sus archivos.Allí se publicó su Anécdota graeca (1783). En 1784 publicó una versión griega de la Biblia (Estrasburgo, 1784) y La lliada (1788). Miembro de la comisión arqueológico-anticuaria enviada a Grecia en 1785, ocupó la cátedra de griego del Colegio de Francia desde 1796.

280. [Heredia - Roda], [s.I.] [s.f./ finales de diciembre de 1776, primeros de enero de 1777].

281. [Heredia - Roda], París, 6 de febrero de 1777.

282. [Heredia - Roda], París, 22 de marzo de 1777. 
Como no podía ser de otra manera, Heredia prestaba también particular atención a las novedades literarias que tenían relación con España. En abril informaba que acababan de aparecer «las Memorias del Mariscal de Noailles, en seis tomos, ordenados por el Abate Millo sobre los manuscritos que para este fin le comunicó la familia ${ }^{283}$. Son interesantes para la historia de Phelipe quinto, porque casi todas ellas giran sobre lo acaecido en la guerra de sucesión; y por lo poco que hasta aquí he podido leer me parece que no le hacen mucho honor a Phelipe $V$; pues hacen ver que desde muy joben dió ya muestras de poca cabeza. No puede llebarlas el correo porque va muy cargado; pero se las embiaré a V.E. en los correos ordinarios para que pueda divertirse en las siestas de ese sition ${ }^{284}$.

Hasta junio de 1777 no organizó Heredia una nueva expedición de libros hacia la corte española. El día 21 comunicaba a Roda que la semana anterior había enviado a Ruán «unos balotes de Libros dirigidos a Alfonso la Higuera en que van para V.E. los que contiene la adjunta lista; y prebendré a aquel que se los entregue a V.E. quando los reciba. El suplemento del Basilicon, y el tomo de Buffon van en papel para que puedan enquadernarse ahí al igual de los otros. El Mauguin no se ha podido hallar sin embargo que se han recorrido todos los libreros, pero queda a mi cuidado embiárselo a V.E. en otra ocasión. Lo mismo ha sucedido con Bartholomé Valverde, de igne Purgatorio ${ }^{285}$; y yo creo que se equivoca V.E. en decirme que estaba en el catálogo que embié a V.E. de Mr. le Marie, pues yo no lo hallo en él, y sí en los de Bore $y$ Rothelin, en donde es regular lo haya visto V.E. En la almoneda de Rhotelin se bendió en 60 libras; en la de Mr. Gaignat que se hizo el año de 1769 en 94, de donde puede inferir V.E. el precio que tendría si se hallara oi» ${ }^{286}$.

En la posdata de la misma carta avisaba de haber llegado aquel mismo día un extraordinario con el anuncio de la suspensión de hostilidades entre España y Portugal en América, de la aparición en París -todavía en inglés- de la obra de Robertson sobre la historia de América, y de la visita del P. Xaupi, quien por recomendación suya decidió eviar un ejemplar de su obra «de los Ciudadanos nobles de Barcelona y Perpiñan» ${ }^{287}$ al Ministro español: «Por lo que he visto -añadía Heredia- me parece

283. Se trata del extracto de las Mémoires de Adriano Mauricio, Duque de Noailles (1678-1766) publicadas por Millat en Maestricht en 1777. MILLO, Claude François Xavier: Mémoires politiques et militaires pour servir à l'histoire de Louis XIV et Louis XV.../ par M. L'abbé Millot, 2 ed. París, chez Moutard, 1777.

284. [Heredia - Roda], París, 13 de abril de 1777.

285. VALVERDE, Bartolomé, S.J.: Ignis purgatorius post hanc vitam, ex Graecis \& Latinis Patribus Orthodoxis, Haebreorumq doctissimis, ac vetustis, assertus / a Bartholamaeo Valverdio \& Gandia.Villenate. Accessit eisudem pro Igne Purgatorio, Sanctorum intercessione...atque... Catholicae Ecclesiae cultibus \& ceremoniis, Apologeticum (Ex Sanctis Patribus Gnomologia) Patavii: Laurentius Pasquatus, 1581. La edición de Venecia, por Felicem Valgrisium, es de 1590.

286. [Heredia - Roda], París, 21 de junio de 1777.

287. XAUPI BONAVENTURE, Abbé. Recherches historiques sur la noblesse des citoyens honorés de Perpignan et de Barcelone; pour servir de suite au traité de la noblesse de La Roque, París, Noyon, 1763, en $8^{\circ}$. PALAU, XXVIII, 189. 
que está muy bien escrita, y lo singular es que el autor tiene noventa años, pero tan fuerte de cabeza y estómago que me ha dicho trabaja diez horas por día, y no he visto otro en la mesa de S.E. que coma más que él. Es Decano de la Sorbona y jansenista, y se ha hallado metido en todas las querellas de este siglo, sobre lo que me divierte muchos ratos» ${ }^{288}$.

Entre el 19 de julio de 1777 y el 4 de agosto de 1778 hay un largo vacío en la correspondencia. Posiblemente se hayan perdido algunas cartas, pero la posición no intervencionista de Floridablanca y Carlos III en el conflicto anglobritánico conllevó cierto distanciamiento ente ambos gobiernos ante las crecientes presiones de Francia para que S.M.C. se dicidiera a intervenir directamente en la guerra, se tradujeron en la pérdida de agilidad de las comunicaciones ${ }^{289}$. Sin embargo, los comentarios político-cultural-literarios se reanudaban sin apenas solución de continuidad: «He visto la cédula que prohive la entrada de libros enquadernados, y sin duda que los que han. andado en ella deben de creer que todo lo que ay que saber en España se halla en los libros del siglo pasado, pues que cierran enteramente la entrada a los de éste. Que no entienda de esta materia el docto Consejo con su Presidente, como decía el Conde de Miranda, no me admira; pero que Sancha y otros libreros y enquadernadores que havrán sido los solicitadores, no les hayan dado a entender lo que pasa en este asunto, no lo comprendo. Quando aprobó el Rey la probidencia havía de haver mandado que el Consejo quedara obligado a hacer benir en papel o a la rústica todos los libros de este siglo que pidieran sus vasallos. Entonces huvieran aprendido lo que aora ignoran, que no los ay. Yo creo que en caso de haver de establecer esta ley, que no se la haya en ningún estado de Europa, el único partido que se puede tomar es de limitar la prohibición a un cierto tiempo después de la impresión. En todo caso sírbase V.E. de decirme si cree que esto puede subsistir porque me vería en grande embarazo con mis libros, que todos los tengo enquadernados.

Supongo que ya havrán llegado ahí los libros que embié en el mes de mayo, de lo que no he tenido noticia» ${ }^{290}$.

En septiembre, al tiempo que comunicaba a Roda que ya tenía en su poder «todas las obritas que V.E. me pidió de Gibert ${ }^{291}$. De Viloison (no a sido jamás Oficial

288. [Heredia - Roda], París, 21 de junio de 1777.

289. Heredia refiere que: «Como el sistema actual de nuestra Corte es de huir el cuerpo a ésta, no van ni vienen correos como antes, y por ese motivo no he acusado hasta aqui el recibo de la de V.E. de 15 de junio». [Heredia - Roda], París, 4 de agosto de 1778.

290. [Heredia - Roda], París, 4 de agosto de 1778. No obstante, que acto seguido haga referencia a haber comprado el Robertson - "He comprado ya a Robertson, pero no se quando havrá ocasión de poder embiarlon-conecta directamente con la carta fechada el 14 de julio de 1777. Al final de esa misma carta apostillaba: «Aunque he dicho al principio que esta carta iría con un correo que despachaba S.E., ha llegado después uno que despacha Almodóvar, con lo que se queda el de S.E. En Londres ignoraban aín a la partida del correo el 31 de julio, la batalla naval». [Heredia - Roda], París, 4 de agosto de 1778.

291. En este caso se refiere a Balthazar GIBERT (1662-1741). La rhetorique ou les regles de l'eloquence / par M. Gibert. A Paris, chez Barbou, rue des Mathurius, 1766 , y no a Jean Pierre Gibert (16601736), canonista destacado por sus posiciones galicanas. 
de Estado) ya embié a V.E. el Apolonio. Recogerê sus otras obras, y estoy seguro de que no son suyos el Píndaro, Anacreonte, y Theócrito, que recibió el Duque de Alba. Encargué al Abate Xaupi que averiguara la historia del Trias patrum, y avisaré a V.E. de la resulta» ${ }^{292}$ daba cuenta también de las aclaraciones que había recibido del impresor Sancha acerca de la prohibición de importar libros extranjeros: «Una carta del famoso Sancha a un librero de acá me desbaneció todas las dificultades que objeté a V.E. contra la cédula de prohivición de entrar libros enquadernados, pues le dice que en adelante será preciso quitarles la enquadernación. Confieso que no me havía ocurrido semejante arbitrio, ni era fácil inferirlo de la cédula, pues viendo exceptuados los libros de los siglos pasados qualquiera creería que era porque no se hallarian en papel. En caso de excepción, ¿no la merecían más los libros de este siglo bien tratados, que no los de los pasados cuyas enquadernaciones están en lo general estropeadas? Es lástima el que cada día demos motivos a los estrangeros de que se confirme en la idea que tienen de nuestra barbarie» ${ }^{293}$.

El 1 de noviembre de 1778 respondía Heredia a algunas de las cuestiones que le había planteado Roda en su última carta de 28 de septiembre: «El author de la obra Trias Patrum es Juan Sinnichio, irlandés, profesor de Lovaina en cuya ciudad se imprimió con motivo de las disputas que havía ocasionado el libro de Jansenio. Los sumarios de dicho Libro son del Dr. Antonio Arnauld como se ve en Moreri al nombre Sinnich ${ }^{294}$.

A más de los libros que ya havía dicho a V.E., he comprado el de los Canales ${ }^{295}$, la Música sacra, y el Longo ${ }^{296}$; y espero embiarlos con otros, que me ha dicho un librero debe remitir a Madrid, no me acuerdo a quien, pero quando llegue el caso lo avisaré a V.E. No he comprado el Theocrito, Anacreonte, y Pindaro, porque la explicación de V.E. me hace ver que cree se ha hecho alguna nueva edición de estos authores, y no es así. Yo los tengo, el Theocrito de la edición de Oxford de 1770 en 2 en

292. [Heredia - Roda], París, 20 de selp]tiembre de 1778.

293. [Heredia - Roda], París, 20 de se[p]tiembre de 1778.

294. SINNICH, Juan (1603-1666) Sinnich fue Rector de Lovaina hasta la condena del Augustinus por Urbano VIII, y el encargado de defender en Roma las tesis de Jansenio junto con Corneille Pape (16091644) Sus obras se centran en la defensa de las tesis jansenistas y en contra del molinismo. Su principal obra sobre la gracia es Sanctorum Patrum Trias, scilicet S. Augustini adversus Pelagium, S. Propseri adversus Cassium, et S. Fulgenti adversus Faustum, de gratia Christi et hominis arbitrio, adversusu ingratos dimicantium, studio Aviti Erunachi, s.1., 1648, in $4^{\circ}$, que apareció publicada con el pseudónimo de «Erynachus, theologus Gratiapolitanus» fue condenada por un decreto de 8 de junio de 1661, manteniendo en otras muchas de sus obras un ácida polémica con los jesuitas. D.T.C. 2165-2166.

295. Heredia compró para sí el libro de N. LINGUET Canaux navigables de Paris, Paris, s.f. 1 vol. En $12^{\circ}$. OLAECHEA, Op. Cit. En $1778 \mathrm{Mr}$. LA LANDE publicó en París Des canaux de navigation, et spécialement du Canal de Languedoc / Par M. de La Lande. A Paris : Chez la Veuve Desaint, 1778.

296. Parece referirse a la edición de Longo Sofista, Longi Pastoralium de Daphnide et Cloe libri IV / curanit varietatem lectionis ac notas $T$. Columbanii..., Lipsiae, sumtubus Io. Friederici Uinii, 1777, y no a las obras del teólogo capuchino Francesco Coriolano (m. 1625). 
$4^{\circ}$ que es la mejor; el Anacreonte de Paw, impreso en Utrecht en 1732, 1 en $4^{a}$; el Píndaro de Benedicto Salmiari 1620, 1 en $4^{\circ}$; la edición excelente de Píndaro es la de Oxford 1697 en fólio, pero es muy rara y no se hallará [a] menos de 130 libras. Tampoco entiendo quien es el Viagero [sic] que V.E. me dice imprimió sólo el primer volumen de lo tocante a Navarra, y que se prohivió por la Corte, pues si ha sido por ésta, no ay acá noticia de la prohibición de otro viage que el del inglés Clarch [sic] en tres tomos en dozavo, de que me parece embié un exemplar a V.E. el primer año que llegué acá» ${ }^{297}$.

En noviembre Heredia organizó una nueva remisión de libros hacia España: «Como por el correo extraordinario havía dicho a V.E. la naturaleza de la enfermedad de S.E. y el estado en que se hallaba, havía esperado a escribir hasta que el librero me avisara que havían partido los libros que anuncié en mi anterior (...) En esta semana ha dirigido el librero por Bayona un balote al Doctor Ellín, que está en casa de Negrete, y van en él para V.E. los libros que contiene la lista adjunta. Quedarán para otra ocasión el_Anacreonte de Paw y el Theocrito de Oxford; y puede V.E. estar seguro de que no se ha hecho aquí edición moderna de los Poetas líricos griegos.

Yo no se si V.E. tiene la obra de Brunck Analecta veterum poetarum graecorum. Argentorati 1773, 3 volúmenes en $8\left[^{\circ}\right]$. Está en griego sólamente, y la oí alabar mucho al difunto Presidente de Dijon. Si V.E. la quiere podrá avisármelo» ${ }^{298}$.

La primera carta conservada de Heredia del año 1779 lleva fecha de 5 de febrero, y además de acusar recibo de algunos envíos hechos por Roda, se ocupaba de la polémica suscitada entre Juan Bautista Muñoz y el P. Pozzi, que armó buen revuelo tanto en Madrid como en Italia.

El padre Pozzi había publicado su célebre Saggio di educazione claustrale ${ }^{299}$, y sobre él, con gran contento de Pérez Bayer, recayó la dura crítica de Juan Bautista Muñoz ${ }^{300}$, poniendo al descubierto la utilización de diversos autores extranjeros, algunos de ellos abiertamente heterodoxos, acusándole de plagiario y de falta de rigor y método $^{30 t}$.

297. [Heredia - Roda], París, 1 de noviembre de 177[8].

298. [Heredia - Roda], París, 23 de noviembre de 1778. Ricardo F. Felipe BRUNCK (1729-1803) Analecta veterum poetarum graecorum Estrasburgo, 1772. Publicó, entre otras obras, Gnomici poetae graeci (1778), Anacreontis carmina, cui accedunt quaedam e lyricorum reliquiis, Oedipus Tyranus., Editor de Apolonio den Rodas (1780); Aristófanes (1783), Sophocles (1786-89), Plauto (1788) y Terencio (1797).

299. POZZI, P. Cesareo. Apologia del P. Cesareo Pozzi abbate della congregaziones Benedictina..., scrit: ta in defessa del suo libro...saggio di educazione claustrale..., [Perpiñán], [s.n], 1780. Ibíd. Saggio di educazione claustrale per glio govani...accomodato alli tempi presenti...dedicato a sua eccellenza ...Don Nicola Colonna de Prencipi di Stigliano, Arcivescopo di Monte Oliveto.. [Roma, 1768]. In Madrid, nell stamperia di Don Antonio de Sancha, 1778.

300. MUÑOZ, J.B. Juicio del Tratado de educación del M.R.P.D. Cesareo Pozzi. Lo escribía por el honor de la Literatura Española..., Madrid, Ibarra, 1778.

301. SARRAILH, J.: La España ilustrada de la segunda mitad del sigto XVIII, Madrid, ed. 1979, pp. 218 y 376 , donde reproduce los juicios de Azara. 
Al respecto Heredia escribía: «He recivido dos cartas de V.E. por los dos últimos extraordinarios que han venido; y los exemplares de Pozzi y Muñoz que traxo el primero.

Después de dar a V.E. las gracias, puedo decirle que entregué luego uno de los de Muñoz a S.E.; y que quedan hechas las diligencias necesarias, por medio de los benedictinos de Blancmantó, para que de cuenta de esta disputa la gaceta ecclesiástica.

Dice V.E. bien que es imposible que Pozzi pueda desenbarazarse de la impugnación, porque ay algunas cosas muy substanciales en materia de doctrina, y los plagios son tan considerables que no ay medio de cohonestarlos. Sólo huviera deseado yo que huviera usado de más moderación Muñoz, y que no se resintiera su obra de la mala educación de nuestras escuelas theológicas» ${ }^{302}$, dedicando luego gran parte de la carta al asunto del libro de Robertson, que ya comentamos en un epígrafe anterior.

Heredia se encontraba, pues, muy lejos de la evaluación ideológica que Pierre Paolo von Giusti hacía del significado de la obra de Pozzi, que tan bien había acogido su admirado Campomanes. Para el enviado de la corte austriaca «...l'intérêt et le peu d'application des ordres monastiques d'Espagne à l'étude feront ici probablement le mêmem effet qu'ailleurs la connaissance de meilleurs principes, c'est á dire qu'elle ne permettra pas que ce livre ontienne aucune espèce de célébrité. Il paraît absurde, pour ne pas dire ridicule aux yeux de la raison et de la vraie politique de vouloir donner une nouvelle forme à une chose dont le fond lui-même ne mérite qu'une supresion entière» ${ }^{303}$.

El 5 de febrero Heredia contestaba a la preocupación de Roda por los desembolsos que hacía el primero en la remisión de los libros: «Es cierto que pagamos los portes de cartas; pero esto puede servir para no embiar grandes pliegos por el correo, pero no para que V.E. dexe de escrivir por él lo que le ocurra, y así se lo suplico a V.E. El año pasado le hizo pagar a S.E. 117 libras la Sociedad de Valencia del libro que le embió de sus Ordenanzas; y al Duque de Bervich 240 de dos exemplares. Ya se lo escrivi a Bayer, pero como la noticia hacía poco honor a su patria se la ha guardado para sí, pues tengo gran motivo de creer que el Dr. Blasco me ha dirigido por el correo un exemplar del papel de Muñoz, que no quise recivirlo porque me figuré lo que era en vista de haverme escrito mi primo haverle dicho que me lo embiaría» ${ }^{304}$. En el mismo sentido volvía a insistir el 1 de mayo: «No me causó nobedad el no haver recivido carta de V.E. por el último correo que pasó a Londres porque supuse que havria ignorado su partida; pero repito a V.E. que no repare en escrivirme, como antes, por el ordinario. Yo adelanto a escrivir esta porque esperamos de un día a otro la buelta del correo de Londres, y no se detendrá acá sino lo muy preciso» ${ }^{305}$.

302. [Heredia - Roda], París, 5 de febrero de 1779.

303. P.P. von Giusti - Kaunits, Madrid, 21 octubre 1778. Apud. Berichthe der Diplomatidchen vertreter des Wiener Hofes aus Spanien.., Madrid, 1887, t. XIII, p.79.

304. [Heredia - Roda], París, 5 de febrero de 1779.

305. [Heredia Roda], París, 1 de maio de 1779. 
En esta ocasión, fue Roda el que dejó pasar algunos meses sin escribir. El 5 de septiembre Heredia mostraba su júbilo por haber recibido carta del Ministro: «Recibí la de V.E. con grandisimo gusto, pues aunque siempre he creido que el no escrivirme $V . E$. dependía de no avisarle la partida de los correos, no dejaba de serme sensible el verme pribado por tanto tiempo de las cartas de V.E. Repito que no repare V.E. en escribirme por el correo siempre que guste, pues todo el gasto puede reducirse a dos o tres pesos al año, que para quien en sólo este lleba gastados más de ciento en cartas de los españoles transeúntes, ya puede V.E. creher que no sentirá esa bagatela en una correspondencia que le es tan apreciable.

Por el correo ordinario de ayer reciví diez cartas de los oficiales de nuestra esquadra, que no conozco, para remitirlas a España. Si, como es regular, previenen a sus corresponsales que respondan por mi mano, esta campaña será más ruinosa para mí que para los ingleses» ${ }^{306}$.

La salud de Roda comenzó un inexorable declinar a finales de 1779 . El 22 de diciembre escribía Heredia: "Por el marqués de Mexorada supe que V.E estaba indispuesto, lo que me tubo con cuidado hasta que me escrivió mi primo se hallaba ya V.E. mejor, aunque todavía con debilidad en la cabeza, de la que deseo se halle V.E. enteramente reparado» ${ }^{307}$. El 3 de marzo volvía referirse a los achaques, ya permanentes del anciano Roda: «... aprobechando de esta ocasión diré a V.E. que me sirvió de mucho gusto su carta por ver que se hallaba V.E. enteramente recobrado de su indisposición, cuya noticia me confirma mi primo en la última carta que me ha escrito de resulta de haver visto a V.E. en el Pardo» ${ }^{308}$. El 19 de febrero de 1781, con una pequeña esquela, en que le remitía un análisis de Necker sobre las finanzas francesas ${ }^{30 \%}$, añadía: «Supe que V.E. estubo desazonado en Madrid, y que se havía ido al Pardo recobrado» ${ }^{310}$.

La correspondencia de 1779 se había centrado esencialmente en las noticias de la guerra, mientras que apenas se hacía mención a los aspectos literarios, tónica que se mantiene también en los dos años siguientes, al tiempo que desaparecen casi todos los matices incisivos de años atrás.

En 1780 Roda se vió elevado a la dignidad de Consejero de Estado y Heredia se apresuró a manifestarse su felicitación de lo que, dadas las circunstancias, era un honor que ponía broche a una larga carrera de servicios a la Corona: «Por no molestar a $V . E$. con una carta de cumplimiento, huviera aguardado a darle la enhorabuena de la plaza del Consejo de Estado quando huviera tenido la ocasión de escrivir por extraordinario. Pero al haverme encargado S.E. el que se la diera a V.E. de su parte, y

306. [Heredia - Roda], París, 5 de se[p]tiembre de 1779.

307. [Heredia - Roda], París, 22 de diciembre de 1779.

308. [Heredia - Roda], París, 3 de marzo de 1780.

309. NECKER, De l'administration des finances de la France, SI. [Localizada ed. 1784]. También Collection complete de tous les ouvrages pour et contre M. Necker..., Utrecht [1782], 3 vols. STAËL, M. Le Baron de. Ouvres complètes de M. Necker, publiées par... A Paris, Treuttel et Würtz, 1820-1821.

310. [Heredia - Roda], París, 19 de febrero de 1781. 
el recelar que haya pronta ocasión de correo, me determinan a no diferirlo más. Recíbala pues V.E. de la parte de S.E., y de la mía que se interesa muy vívamente en todas las satisfacciones de V.E.» ${ }^{3 n}$.

Una de las últimas cartas de Heredia, fechada de 18 de junio de 1780 , viene a corroborar algunas de las afirmaciones que hemos hecho en el sentido de existir ya cierto confusionismo derivado de la pérdida de continuidad de la correspondencia, atribuible sólo en parte a las dificuitades impuestas por la guerra: «Aunque V.E. me da a entender que me escribe por el correo, reciví la de V.E. de 5 del corriente por un extraordinario que llegó acá el 13, y me la incluyó en una suya Don Eugenio Llaguno. Celebro mucho que V.E. se mantenga sin nobedad, pues hacía días que no havía sabido de su salud, e igualmente lo ha celebrado S.E. y apreciado las expresiones de V.E.

Copin no ha aparecido por acá, y sin duda se avrá detenido en León su patria, como lo hizo la otra vez. Si se deja ver le entregaré los libros que V.E. me pide aho$r a$, que son los únicos de que V.E. me ha hablado; pues aunque V.E. supone haverme pedido otros yo no lo tengo presente. Tampoco me acuerdo de quales son los últimos tomos que embié de la Historia natural, y de los Pájaros de Buffon; y de los Oficios y Artes de la Academia de las Ciencias. Sé que de estas obras se han publicado nuevos tomos desde los últimos que remití; con que para poderlos embiar puede V.E. avisármelo.

Me alegro de la elección de P[adre] Scio para maestro de los hijos del Príncipe, pues lo conocí en Madrid, y me regaló la traducción de Colutho, que es la única obra suya que conozco», mientras el resto de la carta, salvo la posdata, se centraba sobre el conflicto con Inglaterra. «Me olbidaba decir a V.E. que no he oido hablar acá de la Apología de Pozzi. Procuraré tomar lengua, pero dudo mucho de que haya llegado por $a c a »^{312}$. Algunos meses después, en carta del 29 de octubre de 1780, escribía Heredia: «Me acuerdo que en la última que escribí a V.E. le decía me avisara quantos volúmenes tenía, o quales eran los últimos de las obras des Arts et Metiers, y de Buffon para comprar los que se han publicado después. Como V.E. no me lo ha dicho, ni tampoco se ha visto por acá Copin, como lo suponía V.E., no le he remitido los libros que entonces me pedía le embiara por él» ${ }^{313}$.

Roda continuó hasta el final mimando a su dama. El 19 de febrero de 1781, en una pequeña esquela, volvía a retomar Heredia el asunto del Ministro Necker: «Hoi se ha publicado acá el papel adjunto en que Mr. de Necker da cuenta de sus operaciones y del estado actual de la hacienda de esta monarquía. Es tan singular esta pieza que luego que me ha ocurrido hacia V.E. un gusto de embiársela. Todos buelven los ojos al Parlamento de Inglaterra, y esperan con curiosidad la impresión que hará en aquel cuerpo. Cuente V.E. que este Ministro que parece tan grande en su pa-

311. [Heredia - Roda], París, 14 de mayo de 1780.

312. [Heredia - Roda], París, 18 de junio de 1780.

313. [Heredia - Roda], París, 29 de octubre de 1780. 
pel, aumenta de valor quando se sabe que sirbe de valde, sin que le cueste un maravedí al Estado; y que no quiere ninguna recompensa» ${ }^{3 / 4}$, y dos meses más tarde comentaba la nueva guerra de libelos abierta contra el ministro reformador: «No han faltado acá papelones obscuros contra Necker; pero generalmente se han mirado con el mayor desprecio. Del que más se habló fue de uno que se encontró en casa de un librero para imprimirlo, y se justificó por el Liutenant de Police ser el author el Tesorero del Sr. Conde de Artois, y las notas marginales de su Superintendente de Hacienda. Este Señor receloso de que Necker solicitara su castigo, de lo que estaba muy lejos, lo embió a llamar, y parece que haviéndolo hallado Necker mal instruido lo redujo a que hiciera examinar el asunto por su Canciller, hombre de mucho juicio y razón, de lo que resultó embiarle al mismo Canciller para anunciarle que quedaba plenamente combencido de su razón, y no contento de ésto hizo que el Canciller le escribiera después lo mismo que le havía dicho de palabra.

No hablo a V.E. de noticias públicas, porque ya serán rancias quando llegue esta carta. S.E. se mantiene sin nobedad, y apreció como siempre las expresiones que le di de V.E.» ${ }^{315}$

En la última carta que se conserva de esta «curiosa correspondencia», datada el 11 de abril de 1781, se abordaban también los postreros coletazos de asunsto de Olavide y, como se acaba de ver, al buen crédito de Necker a pesar de la circulación de algunos libelos, le informaba que «por el Abate Álbarez dirijo a V.E. esta carta con el gran volúmen de las leyes criminales ${ }^{316}, y$ los tres tomitos enquadernados (único exemplar que havía venal) de la Vida de Jesu Christo, que era una de las obras que V.E. me havía pedido por Copin. Incluyo la nota de los libros con sus precios; y a excepción de las dos obras que lleba el Abate, las demás continuaré en dirigirlas por los ordinarios.

Por la lista verá V.E. que embio todos los libros que me ha pedido, a excepción de la colección sobre los espectáculos, cuya obra no se tiene acá noticia que haya existido; y sin duda nace la equivocación de creer obra separada una parte de la de Mr. Desprez de Boissy ${ }^{317}$ que trata de todos los autores que han escrito sobre este asunto», añadiendo por despedida que no le contaba nada acerca de «noticias públicas, porque ya serán rancias quando llegue esta carta. S.E. se mantiene sin nobedad, y apreció como siempre las expresiones que le dí de V.E.» ${ }^{318}$

314. [Heredia - Roda], París, 19 de febrero de 1781.

315. [Heredia - Roda], París, 11 de abril de 1781.

316. VOUGLANS. Muyart de. Les loix criminelles de France : dans leur ordre naturel ... / par M. Muyart de Vouglans. A Paris : chez Merigot le jeune, Crapart, [et] Benôt Morin, 1780.

317. DESPREZ DE BOISSY, Charles. Histoire des ouvrages pour \& contre les théatres. Lettres sur les spectacles / Avec une Histoire des ouvrages pour \& contre les théatres / par M. Desprez de Boissy; Paris, Boudet, 2 vols, $6^{\text {a }}$. Editado en 1759 y reeditado en 1774,1777 y 1780 , en 2 tomos en $12^{\circ}$, con un «Catálogo razonado de las obras a favor y en contra de los teatros». D.T.C. p. 631.

318. [Heredia - Roda], París, 11 de abril de 1781. 
Manuel de Roda murió en Madrid el día 30 de agosto de 1782, y sus servicios a la corona fueron premiados con la concesión de un título de Castilla -el de marqués de Roda- a su heredero Miguel Joaquín de Lorieri, ministro del Consejo Real y casado con Francisca de Alpuente y Roda, sobrina del Ministro ${ }^{319}$.

Heredia fue enviado por Aranda a Londres para ajustar los detalles de los acuerdos preliminares de los tratados de la paz de Versailles. Don Ingacio salió de París el 18 de diciembre de 1782, para regresar, tras cinco meses de ausencia, en mayo de 1783 , no sin realizar antes una tourné por las campiñas inglesas, visitar Bristol y Portsmouth y tomarle el pulso al país. Luego, tras embarcar en Calais viajó también durante un mes más por los Países Bajos. Sin embargo, y a pesar del relativamente buen resultado a que se llegó con la firma de los preliminares en París el 20 de enero de $1783^{320}$, Floridablanca no podía ver con buenos ojos la recomendación de Aranda para que Heredia ascendiese a Ministro ante la Corte de San Jorge. Moñino optó por colocar allí a una de sus hechuras, el covachuelista Bernardo del Campo, mientras que a Heredia se le concedía una plaza de Ministro de capa y espada en el Consejo de Guerra, aunque recomendándole que, por el momento, permaneciera en París al servicio de Aranda ${ }^{321}$.

Para el conde de Aranda, la negociación concluida en Versailles parecía abrirle nuevas espectativas para regresar a la corte de Madrid y cuando consiguió la licencia para regresar a España, fue Heredia quien actuó en calidad de encargado de negocios desde noviembre de 1783 hasta el regreso de Aranda a París, el 20 de mayo de 1784, acompañado ahora por su nueva joven consorte y sorbina María del Pilar Fernández de Híjar.

En 1787, tras concluir el que sería el último de los asuntos diplomáticos de importancia -el Tratado de límites-, y puesto que Aranda estaba ya firmemente resuelto a regresar a España, Heredia preparó también su viaje de vuelta: «Pienso salir de aquí -escribía a Floridablanca- hacia el 20 de abril, y haré mi viaje por Cataluña, para ver en Aragón a los parientes que me han quedado, y a los nuevos que me han nacido, con treinta años cabales que hace que sali de mi casa para esa Corte. Esto retrasará mi llegada ahí hasta el mes de junio» ${ }^{322}$.

El 26 de abril Ignacio de Heredia abandonaba definitivamente París y, tras un breve periplo por su tierra aragonesa, se incorporó a la Corte en septiembre de 1787 para ocupar plaza en el Consejo de Guerra, que sirvió hasta su muerte, sobrevenida en Madrid el 20 de marzo de 1792 a la edad de 61 años. La Gaceta de Madrid recogía una breve nota necrológica de Don Ignacio: «Caballero de la Real Orden Española de Carlos III, y Ministro de capa y espada en el Supremo Consejo de Guerra. Sirvió

319. También Carlos III otorgó una pensión de 2.000 ducados a los hijos de Lorieri, Felipe y Sabas. GÓMEZ RIVERO, R. Los orígenes del Ministerio de Justicia (1714-1812). Madrid, 1988, p. 91.

320. El tratado definitivo de paz, o de Versalles, lo firmaron Aranda y el duque de Manchester el 3 de septiembre de 1783. GÓMEZ DEL CAMPILLO. Op. Cit., pp. 108-109.

321. OLAECHEA. «Ignacio de Heredia y su biblioteca», 237-241.

322. Heredia - Floridablanca, París, 26 de febrero de 1787. A.H.N. Estado, leg. 3.445. Apud. OLAECHEA. «Ignacio de Heredia y su biblioteca», p. 257. 
a S.M. más de 30 años así en el referido empleo, como en los de Secretario de la Comandancia general de Valencia, de la de Castilla la Nueva, y de la Presidencia del Consejo, Oficial de la primera Secretaría de Estado, y Secretario de la Embaxada del Rey en París, de donde pasó a Inglaterra con la honrosa y árdua comisión de establecer los preliminares del último Tratado de paz con aquella Corona; cuyos encargos desempeñó como correspondía a la confianza que se hizo de su zelo y talento» ${ }^{323}$.

323. Gaceta de Madrid del viernes 30 de marzo de 1792, p. 207. 
I.- Libros comprados para el Sr. Don Manuel de Roda con sus precios

\begin{tabular}{|c|c|c|}
\hline & TOMOS & $\begin{array}{c}\text { PRECIO } \\
\text { Libras }\end{array}$ \\
\hline - Todas las obras de Mr. Buffon de la Imprenta real ${ }^{324}$ & 20 en $4^{\circ}$ & 240 \\
\hline - Tute l'opere de Dante en gran papel con figuras. Venetiis & 5 en $4^{\circ}$ & 128,19 \\
\hline - Bergier. Histoire des grands chemins. Bruselles, $1728^{325}$ & 2 en $4^{\circ}$ & 24 \\
\hline - Hadriani Relandi. Palestina traiecti ${ }^{326} 1711$ & 2 en $4^{\circ}$ & 20 \\
\hline $\begin{array}{l}\text { - Bartholomei de las Casas, Narratio ciudelitatu. Hamb[urgo]. } \\
1598^{327}\end{array}$ & 1 en $4^{\circ}$ & 21,4 \\
\hline - Limborch Historia Inquisitionis ${ }^{328}$. Amstel. 1692 & 1 en fol. & 20 \\
\hline - Idem. De veritate religionis christianae ${ }^{329}$, Goudae. 1687 & 1 en $4^{\circ}$ & 17 \\
\hline - Meibonieres de fabrica trirrenieum. Amstel, 1671 & 1 en $4^{\circ}$ & 9,4 \\
\hline - Opalius. Epístola de fabrica Meiboniana. Cleut, 1672 & 1 en $4^{\circ}$ & 6,19 \\
\hline - Antique urbis Romae simulacrum. Romae, 1532 & 1 en fol & 10,5 \\
\hline - Dissertatio sistons Palingenesiam. Hotae, 1717 & 1 en & 10,1 \\
\hline - Hipocratis opera curantae Vander Linden ${ }^{330}$. Lug. Ba & 2 en $8^{\circ}$ & 36 \\
\hline
\end{tabular}

324. BUFFON, George Louis Leclerc, Comte de. Histoire naturelle générale et particulière avec la description du Cabinet du Roy, Paris, de l'Imprimerie Royale, 15 tomos, 1749-1767, Histoire naturelle, générale et particuliere servant de suite à la thèorie de la Terre... ... / par M. le Comte de Buffon ... ; A Paris,de L'impremerie Royale, 1774-1778; Manuel du naturaliste: ouvrage utile aux voyageurs... I par M. de Buffon...; A Paris: de 1'Imprimerie Royale, 1771, 2 vols.; Histoire naturelle des oiseaux...: [par M. de Buffon] A Paris, de l'Imprimerie Royale, 6 vols, 1770-1779.

325. BERGIER, Nicolás. Histoire des grans chemins de l'Empire Romain: contenat l'origine, progrès \& etendué quasi incroyable des chemins militaires, pavez depuis la ville de Rome jusques aux extremites de son empire ... Bruxelles: chez Jean Leonard..., 1736, Histoire des grands chemins de l'Empir romain: Contenant l'origine, progrés \& estendu e des chemins militaires panez drepuis la ville de Rome insques aux extremitez de son Empire ou se voit... l'esclarcissement de l'itineraire d'Antonin et de la Carte de Pentinger / par Nicolas Bergier, Paris : chez C. Morel..., 1622.

326. RELAND, Adrien: Hadriani Relandi Palaestina ex monumentis veteribus illustrata: Trajecti Batavorum: ex libraria Guilielmi Broedelet, 17142 vols.

327. CASAS, Bartolomé de las. Narratio regionvm Indicarvm per Hispanos gvosdan deuastatarum verissima..., Franckfurt, 1598. Vid. Brevíssima relación de la destruyción de las Indias / Bartolomé de las Casas; con los grabados originales de la edición latina de Jean Thèodore y Jean Isräel de Bry, Frankfurt, 1598; edición de Andrés Moreno Mengibar, Sevilla, 1991. Revista de Filosofía; Napoli: Instituto Italiano de Studi Filosofici, D.L. 1991, XXXII, 173 p.

328. LIMBORCH, Philippus van, (1633-1712): Historia inquisitionis, cui subjungitur Liber sententiarum inquisitionis Tholosanae ab anno Christi CICCCCVII ad annum CICCCCXXIII..., Amstelodami, Apud H. Wetstenium, 1692.

329. LIMBORCH, Philippi. De veritate religionis Christianae: amica collatio cum erudito Judaeo... [Basilea, 1740] No he localizado la edición citada.

330. LINDEN, Joannes Antonides van der, ed. lit. Magni Hippocratis coi Opera Omnia: Graece \& Latine edita et ad omnes alias editiones accommodata / industriâ [et] diligentia Joan. Antonidae vandes Linden... Lugduni Batavorum: apud Daniclem, Abrahamum \& Adrianum à Gaasbeeck, 1665. 
- Itinerarium Benjaminis ${ }^{331}$. Lug. Bat, 1633

- Sanarapius. Amsterolami, 1720

- Refutation des erreurs d'Espinosa ${ }^{332}$. Bruselles, 1731

$\begin{array}{lc}1 \text { en } 12^{\circ} & 7 \\ 1 \text { en } 8^{\circ} & 7 \\ 1 \text { en } 12^{\circ} & 12 \\ 1 \text { en } 12^{\circ} & 9,19 \\ & 582,11\end{array}$

- Si la torture est un moien sur ${ }^{333}$, etc. Amsterdam 1681

582,11

II.- Nota: Estos libros van ahora, los que siguen los he embiado por los correos

- La Divina comedia de Dante. París 1768

- Aman, Dissertatio de loqueta. Amtel. 1700

- Poza, de la antigua lengua ${ }^{334}$. Bilbao 1587

- Anthologiae graecae. Oxoniae 1766

- Pauli tertii epistola ad Carolum V ${ }^{335}$. París, 1543

- Catalogue librorum qui in thesauris. Leidae, 1725

- Aglosostomographie ou description d'une langue, 1630

- Klotzius de libris autor suis fatalibus ${ }^{336}$, Lipsiae, 1761

- Relandus dissertatio de incript. Num. samarit ${ }^{337}$. Amst. 1702

- Cartas de Ganganelli 338

$\begin{array}{lc}2 \text { en } 12 & 8,2 \\ 1 \text { en } 8^{\circ} & 5,10 \\ 1 \text { en } 4^{\circ} & 12 \\ 1 \text { en } 8^{\circ} & 8,15 \\ 1 \text { en } 12^{\circ} & 1,11 \\ 1 \text { en } 8^{\circ} & 3,11 \\ 1 \text { en } 12^{\circ} & 13,1 \\ 1 \text { en } 8^{\circ} & 8,12 \\ 1 \text { en } 12^{\circ} & 2,10 \\ 1 \text { en } 12^{\circ} & 4\end{array}$

331. BENJAMIN DE TUDELA Ybrlstw'sm zytynb / Itinerarium D. Beniaminis / cum versione \& notis Constantini l'Empereur ab Oppyck... Lugd. Batavorum : ex Officiná Elzeviriana, 1633.

332. FÉNELON, François de Salignac de La Mothe (1651-1715.): Rèfutation des erreurs de Benoit Spinosa, par $M$. de Fenelon, le P. Lami, et par M. le comte de Boullainvillers. Avec la vie de Spinosa, escrite par Jean Colerus... augm. de beaucoup de particularités tirèes d'une vie manuscrite de ce philosophe, faite par un de ses amis. Bruxelles, F. Foppens, 1731.

333. NICOLÁS, Augustin, (1622-1695) Si la torture est un moyen seur a verifier les crimes secrets; dissertation morale et juridique, par laquelle il est amplement traitté des abus qui se commettent par tour en l'instruction des procés criminels, \& particulierement en la recherche du sortilege. Ouvrage necessaire à tous juges, tant souverains que subalternes, \& ¿ tous avocats consultans \& patrocinans. Amsterdam, A. Wolfgang, 1681.

334. POZA, Andres de. De la antigua lengua poblaciones y comarcas de las Españas: en que de paso se tocan algunas cosas de la Cantabria / compuesto por... Andres de Poça, Impresso en Bilbao: por Mathias Mares, 1587.

335. PAULO, III. Pauli Tertii Pont. Max. ad Carolum V. Imp. Epistola hortatoria ad pacem / Ipsius Caroli tum ad eam, tum ad alias eiusdem, Concilii convocatorias responsio. Francisci... Francorum Regis adversus ipsius Caroli calumnias [sl, sf].

336. Solo he podido encontrar la obra de BACH, Johann August, (1721-1758): Opuscula ad historiam et jurisprudentiam spectantis collegit et prefatus est Christ. Adolphus Klotzius. Halae, Curtius, 1767.

337. No he encontrado esta obra en concreto del hebraista Reland, autor de Analecta rabbinica... in usum collegii rabbinici... Trajecti ad Rhenum: ex libraria Jacobi à Poolsom et Jacobi Broedelet, 1723; Antiquitates Sacrae Veterum Hebraeorum / breviter delineatae ab Hadriano Relando Traiecti ad Rhenum: Ex Libraria Ioannis Broedelet, 1741; Antiquitatis Sacrae Veterum Hebraeorum... / notas et animadversiones adiecit loh. Eberhardus Ravius... Herbornae: excudit B. Joh. Nicolai Andreae, Acad. typographi Vidua, 1743.

338. Clemente XIV. Lettres intéressantes du Pape Clément XIV (Ganganelli, A Paris, chez Lottin, 1776. Nipho tradujo al castellano las Cartas importantes del Papa Clemente XIV... / Coleccion formada por 
III.- Memoria de los Libros que van en un balote para el Sr. Don Manuel de Roda, y sus precios ${ }^{340}$.

- Thiers Exposition du St. Sacrement ${ }^{341}$

- Idem. Cloture des religieuses ${ }^{342}$

- Idem. Apologie de l'Abbe de la Trape ${ }^{343}$

- Idem. La plus solide debotion ${ }^{344}$

- Idem. Depoulle des Curés

- Idem. De festorum imminutione ${ }^{345}$

- Idem. Consultation sur la disminution du festes ${ }^{346}$

- Idem. L'Advocat des pauvres ${ }^{347}$

- Idem. Traité des Cloches ${ }^{348}$

- Idem. Factum contre le Chapitre de Chartres

- Idem. Disertations Ecclesiastiques ${ }^{349}$

$\begin{array}{ll}2 \text { vols } & 6 \\ 1 & 3 \\ 1 & 5 \\ 2 & 6 \\ 1 & 3 \\ 1 & 3 \\ 1 & 3 \\ 1 & 3 \\ 1 & 3 \\ 1 & 4 \\ 1 & 5\end{array}$

el marques Caracciolo; traducidas de francés en castellano por Francisco Mariano Nipho, 2 vols. Madrid, 1777. Caraccioli, Louis Antoine de, Marquis (1721-1803) La vie du pape Clément XIV (Ganganelli)/par M. Carraccioli. A Paris : chez la veuve Desaint..., 1776.

339. Parece hacer referencia a la Lettre pastorale aux nouveaux convertis du diòcese de Meaux, París, 1686.

340. [Heredia - Roda], París, 10 de octubre de 1776.

341. THIERS, Jean-Baptiste: (1636-1703) Traité de l'exposition du S. Sacrement de l'autel / par M. JeanBaptiste Thiers..., Paris, 1673, 1677, 1679, Avignon, 1677, con numerosas ediciones, como la de París, de 1777.

342. THIERS, Jean-Baptiste. Traité de la clôture des religieuses, A Paris, Chez Antoine Dezallier, 1681.

343. THIERS, Jean-Baptiste. Apologie de mr. L'abé de la Trape contre les calomnies de P. De SainteMarthe, Grenoble, 1694.

344. THIERS, Jean-Baptiste: De la plus solide, la plus necessaire, et souvent la plus neglige'e de toutes les devotions / par M. Jean Baptiste Thiers... A Paris : Chez Jean de Nully, rue S. Jacques, a l'image Saint Pierre, 1702-1703, 2 vols.

345. THIERS, Jean-Baptiste. De festorum dierum imminutione pro defensiones constitutionum Urbani VIII et gallicanae Eclesiae pontificum, Lugduny, apud Petrum Guillimin,... 1668, que fue colocada en Indice romano en 1762.

346. THIERS, Jean-Baptiste. Consultation faite per un avocat du diocèse de Saintes à son curé, La Rochelle, 1670, sobre la reducción del número de fiestas.

347. THIERS, Jean-Baptiste. L'advocat des pauvres, Paris, Chez la veuve de Jean du Puis, 1676.

348. THIERS, Jean-Baptiste. Traité des cloches, et de la Sainteté del'offrande du pain et du vin aux messes de morts, non confondu avec le pain et le vin qu'on offroit sur les tombeaux. Par ... Jean-Baptiste Thiers ..., Paris, 1721. Red. por Benoît Morin, [1781].

349. THIERS, Jean-Baptiste. Dissertations ecclesiastiques: sur les principaux autels des eglises, les jubés des eglises, la clôture du choeur des eglises / par M. Jean-Baptiste Thiers ... A Paris : chez Antoine Dezallier..., 1688. 
- Idem. Traité des jeux ${ }^{350}$

- Idem. Ste. Iaime avec la critique et la reponse

- Idem. Adversus Launoium, cum opere huius ${ }^{351}$

- Idem. De Stola ${ }^{352}$

- Idem. Dissertation sur Sn. Fermon avec la reponse

- Idem. Critique de I'histoire des flagellans ${ }^{353}$

- Idem. Des Superstitions ${ }^{354}$

- Idem. Sauce Robert ${ }^{355}$ edition originale

- Idem. Inscription du Portaill des Cordeliers ${ }^{356}$

- Idem. De retinenda voce Paraclitus

- Idem. Observations sur le nouveau Breviaire de Cluni ${ }^{357}$

- Vaillant. Botanicon Parisiense ${ }^{358}$

- Ocho Quadernos de Oficios y Artes

- Memoires pour servir à l'histoire de Christine ${ }^{359}$

- Bibliotheque de David Clement ${ }^{360}$

$\begin{array}{lcc}1 & 5 \\ 3 \text { en } 1 & 9 \\ 2 & & 9 \\ 1 & & 3 \\ 2 & & 6 \\ 1 & 3 \\ 2 & 14 \\ 1 & 15 \\ 1 & 12 \\ 1 & 9 \\ 2 & 48 \\ 1 \text { en fol. } & 33 \\ 8 \text { en fol. } & 155,10 \\ 4 \text { en } 4^{\circ} & 14 \\ 9 \text { en } 4^{\circ} & 108,18 \\ 15 \text { en } 12^{\circ} & 38,15\end{array}$

350. THIERS, Jean-Baptiste. Traité des jeux et des divertisements, qui peuvent être permis, A Paris, chez Antoine Dezallier, 1686.

351. THIERS, Jean-Baptiste. Exercitatio adversus J. Launoii dissertationen de auctoritate negantis argumenti, Paris, 1662, en la que criticaba el uso abusivo que a su juicio hacía Launoy del argumentum a silentio, que originó una polémica entre ambos autores.

352. THIERS, Jean-Baptiste. De stola in archidiaconorum visitationibus gestanda... Parisiis, apud Johannem Du Puis, [1784].

353. THIERS, Jean-Baptiste. Critique de l'Histoire des flagellans de l'abbé Boileau, et justification del'usage des disciplines volontaires, Paris, Chez Jean de Nully, 1703.

354. THIERS, Jean-Baptiste. Traité des superstitions qui regarden les sacremens, selon l'Ecriture Sainte, les Décrets des Conciles, \& les sentimens des Saints Peres, \& des Théologiens / par... Jean-Baptiste Thiers, A Paris Chez Jean Nully, 1704, 4 vols.; chez Antoine Dezallier, 1712, 2 vols, Ibid. Compaigne des Libraires, 1741, 4 vols; A Avignon : chez Louis Chambeau..., 1777, 3 vols.

355. THIERS, Jean-Baptiste. La sauce Robert justifiée, [H. 1679].

356. THIERS, Jean-Baptiste - Sur l'incription du grand portail du convent des cordeliers de Reims: DEO HOMINI ET BEATO FANCISCO UTRIQUE CRUCIFIXIO, par le sieur de Sainte-Saveur, Bruselles, 1670.

357. THIERS, Jean-Baptiste Thiers, Jean-Baptiste, Observations sur le nouveau Breviaire de Cluni / par Jean-Baptiste Thiers. Bruxelles : Claude Plantin, 1702

358. VAILLANT, Sebastián (1669-1722) Su Botanicon Parisiense fue publicado por Boerhaave en Amsterdam-Leyden en 1727.

359. ARCKENHOLTZ, Johan (1695-1777): Memoires concernant Christine reine de Suede, pour servir d'eclaircissement a l'histoire de son regne et principalement de sa vie privée, et aux evenemens de l'histoire de son tems civile et litèraire: suivis de deux ouvrages de cette savante princesse, qui n'ont jamais étè imprimés. A Amsterdam et a Leipzig, : Chez Pierre Mortier, 1751-1760. 4 vols.

360. CLEMENT, David (1710-1760) Bibliotheque curieuse historique et critique, ou Catalogue raisonné de livres difficiles a trouver/par David Clement; 9 vols, Gotinga, 1751-1760.

361. LENGLET DU FRESNOI, Methode pour etudier l'histoire avec un Catalogue des principaux historiens, \& des remarques sur la bonté de leurs ouvrages \& sur le choix des meilleures editions / par $M$. 
- Idem. Disertations sur les apparitions ${ }^{362}$ brochés

6 en $12^{\circ} \quad 1,10$

- Idem. Du secret inviolable de la confession

1 en $12^{\circ} \quad 1,10$

- Collection des Nouvelles ecclesiastiques comenzant en 1713 jusqe compris $1775^{363}$

- Pour la subscripción de dicha gaceta para este año

18 en $4^{\circ} \quad 76$

- Por embalage de los libros, conducción a Rouan, y seguro de

la cantidad de quinientas libras

10

Importa todo

\section{IV.- Nota de los libros que van en el mismo Balote para el Señor D. Manuel de Roda}

- Voyage de Cook ${ }^{364}$

- Code des Loix des Indiens, broché 365

- Buffon tomo 22 en papel

- Etoffes de Soie suite de la 7 me section, 1 en fol

- Peches $3^{\circ}$ partie le section

- Trias Patrum de gratia dinicantium ${ }^{366}$
4 en $4^{\circ}$

1 en $4^{\circ}$

1 en $4^{\circ}$

1 en fol.

1 en fol

1 en $4^{\circ}$

l'abbé Lenglet du Fresnoy. A Amsterdam: aux depens de la Compagnie, 1737; Supplement de la Methode pour étudier l'histoire... / par M. l'abbé Lenglet du Fresnoy. A Paris: chez Rollin fils... [et al.], 1740, 3 vols; Méthode pour étudier l'histoire: avec un catalogue des prèncipaux historiens; accompagné de remarques sur la bonté de leurs ouvrages \&c sur le choix des meilleures éditions / par M. L'abbé lenglet du Fresnoy.., A Paris: chez Debure... [et] N.M. Tilliard..., 1772 (De l'Imprimerie de la veure Simon \&cfils...), en 15 vols.

362. LENGLET DU FRENOY, Recueil de dissertations anciennes et nouvelles sur les apparitions, les visions \& les ronges : avec une préface historique / par M. l'Abbé Lenglet Dufresnoy; A Avignon et se trouve a Paris: chez Jean-Noel Leloup..., 1751.

363. Las Nouvelles Ecclésiastiques.-»organe clandestin des jansénistes français» escribía Jöel Saugnieux fue uno de los principales canales para conocer las obras extranjeras afines a estas corrientes ideológicas, de manera que: «Toute connaissance du jansenisme espagnol passe par l'etude des "Nouveleles" Que de nombreux prélats recevaient et qui fut le véhicule ordinire des "Lumieres" dans les milieux ecclesiástiques». SAUGNIEUX, J. Le jansenisme espagnol du XVIIIe siècle, ses composants et ses sources, Oviedo, 1975, p 114-115, y nota 2.

364. COOK, James. Voyage dans l'hemisphère austral et autour du monde ... / ecrit par Jacques Cook ...; dans lequel on a inséré la relation du capitaine Furneaux \& celle de MM. Forster; traduit del'anglois... M. Hodges; A Paris: hôtel de Thou ..., 1778, 4 vols. En 1777 se publicó en Inglaterra: $A$ voyage towards the Soth Pole and around the world ... / written by Jmes Cook ...; in which is included captain Furneaux's narrative of his proceeding in the adventure during the saparation of the ships...; 2 vols: London: printed for W. Strahan and T. Cadell ..., 1777, $2^{a}$ ed.

365. VOUGLANS, Muyart de. Les loix criminelles de France dans leur ordre naturel ... / par M. Muyart de Vouglans. A Paris : chez Merigot le jeune, Crapart, [et] Benoît Morin, 1780.

366. SINNICH, Juan Sanctorum Patrum Trias, scilicet S. Augustini adversus Pelagium, S. Propseri adversus Cassium, et $S$. Fulgenti adversus Faustum, de gratia Christi et hominis arbitrio, adversusu ingratos dimicantium, studio Aviti Erunachi, s.I., 1648, in $4^{\circ}$, publicada con el pseudónimo de «Erynachus, theologus Gratiapolitanus» D.T.C. 2165-2166. 
V.- Nota de los libros que se remiten al Dr. Ellin para el Sr. D. Manuel de Roda

- Les Canaux de M. De la Lande

1 en fol. $\quad 50$

- Fauteur d'orges

- Guberti [?], de cantu et musica sacra

1 en fol.

- Tacito ${ }^{368}$ de Brotier

2 en $4^{\circ} \quad 24,10$

- Robertson, Histoire de l'Amerique ${ }^{369}$

4 en $4^{\circ} \quad 90$

- Tomo 5 du Voiage de Cock

2 en $4^{\circ} \quad 24$

- Tomo 4 des Oiseaux de Buffon en papel

1 en $4^{\circ} \quad 12$

- Longi Pastoralia de Daphnide et Cloe ${ }^{370}$

1 en $4^{\circ} 1 \quad 12$

- Jugement des Savans ${ }^{371}$

1 en $8^{\circ}$

- Rethorique de Gibert ${ }^{372}$

3 en $12^{\circ}$

1 en $12^{\circ}$

- Observations adressèes a Mr. Ro[1]lin ${ }^{373}$

Total:

VI.- Relación de libros que Heredia envía a Roda, y que no figuran en los listados anteriores:

Clarke, E. Etat présent de L'Espagne... ${ }^{374}$

Prospectus de las Observations del Abate Gorier

Memoria de Linguet sobre su proceso

367. OPSTRAET, Joanne S.T.L: Pastor bonus, seu Idea, officium, et praxis pastorum... : Editio prima Veneta Vicentiae: apud Antonium Veronese, 1769; Ibid. Venetiis : sumpt. Heredis Nicolai Pezzana, 1771.

368. TÁCITO: C. Cornelii Taciti opera / supplementis notis et dissertationibus illustravit Gabriel Brotier; tomus primus. Parisiis : ex typographia L.F. Delatour ..., 1776, 4 vols.

369. ROBERTSON, William (1721-1793) L'histoire de l'Amérique / par M. Robertson ... ; traduite de l'anglois..., A Paris : chez Pissot, 1780, 4 vols.

370. Longi Pastoralium de Daphnide et Cloe libri $\mathrm{V} / \mathrm{curanit}$ varietatem lectionis ac notas $T$. Columbanii..., Lipsiae, sumtubus Io. Friederici Uinii, 1777.

371. GIBERT, Balthazar (1662-1741): Jugemens des sauans sur les auteurs qui ont traité de la rhetorique / par M. Gibert ..., A Amsterdam : aux depens de la Compagnie, 1725.

372. GIBERT, Balthazar: La rhetorique ou les regles de l'eloquence / par M. Gibert. A Paris, chez Barbou, rue des Mathurius, 1766. Trad. Española: Rhetorica ó Reglas de la Eloquencia / por Mr. Gibert...; traducidas del frances al castellano por don Blas Molina y Tolosa... , Madrid: en la oficina de la viuda é hijo de Marin, 1792.

373. GIBERT, Balthazar: Obseruations adressées a Mr. Rollin ... sur son Traité de la mainere d'enseigner \& d'étudier les belles-lettres / par Mr. Gibert A Paris : chez François-Guillaume l'Hermitte..., 1727.

374. CLARKE, Edouard, Etat présent de L'Espagne et de la nation espagnole: Lettres ecrites a Madrid, pendant les annes $1760 \& 1761 / .2$ vols, Bruselas/París, 1770. 
Memoria de Caron de Beaumarchais

Números 1 a 3 del Diario Literario de España, de Torres

L'Epeé ${ }^{375}$

Sermón de Obispo de Sener

Catálogo de la biblioteca de Mr.Lemarié

Obras de Necker, Beaudau y Galiani ${ }^{376}$ sobre granos 3 vols

Historia de los estados barbarescos 2 vols

Concilio de Basilea d l'Enfant

Historia de Pierre de Montmaur de Salengre ${ }^{377}$, con las piezas de Menage

Basilicon [Basilikos] de Fabroto ${ }^{378}$

2 en $4^{\circ}$

Amusement de la langue de les betes ${ }^{379}$

[7 En fol]

1 en $12^{\circ}$

Catálogo de Panckouke

Memorias de Noailles ${ }^{380}$

Salustio, de Broses

Chaupi [Xaupi], De los ciudanos

Abate Morelet ${ }^{381}$

Necker, estado actual monarquía ${ }^{382}$

3 tomos vida Jesucristo

Denuncia el Parlamento contra los Jesuitas

Carta de Linguet a Vegennes

373. GIBERT, Balthazar: Obseruations adressées a Mr. Rollin ... sur son Traité de la mainere d'enseigner \& d'étudier les helles-lettres / par Mr. Gibert A Paris: chez François-Guillaume 1'Hermitte..., 1727.

374. CLARKE, Edouard, Etat présent de L'Espagne et de la nation espagnole: Lettres ecrites a Madrid, pendant les annes $1760 \& 1761 / .2$ vols, Bruselas/París, 1770.

375. L'EPEÉ, Charles M (1712-1789). Institutions des sourdes et muets par la voie des signes methódiques, Paris, 1776.

376. GALIANI, F. (1728-1787) Dialogues sur le commerce des blés, Paris, 1764.

377. SALLENGRE, Albert Henrik de (1694-1728), autor de Novus thesaurus antiquitatum romanarum / congestus ab Alberto Henrico de Sallengre ...; tomus primus. Hagae-Comitum: apud Henricum du Sauzet; et Parisiis: apud Antonium Vrbanum Coustelier, 1716. La obra completa constaba de 3 volúmenes.

378. FABROTTO, Carlo Annibale (1580-1659) Ton basilikon biblia XI. Basilikon libri LX in VII tomos divisi. Parisiis, Sumptibus Sebastiani Cramoisny ...et Gabrielis Chamoisy, MDCXLVII, 7 tomos in fol, con los textos griego y latino.

379. Amusement philosophique sur le langage des bestes Troisiéme edition / augmentée de la lettre de l'auteur \& de la critique. (A Paris: chez Gissey...: [chez] Bordelet...: [chez] Ganeau..., 1740).

380. MILLO, Claude François Xavier: Mémoires politiques et militaires pour servir à l'histoire de Louis XIV et Louis XV.../ par M. L'abbé Millot, 2 ed. París, chez Moutard, 1777.

381. Roda anota en una esquela que Heredia le remitio «un libro publicado en 1762 por el abate Morelet en punto de Jnquisición».

382. NECKER, De l'administration des finances de la France, S1. 
383. LENGLET DU FRESNOY, Nicolas (S.I.) Principes de l'histoire pour l'education de la jeunesse: sixième année: Histoire de l'Eglise / par M. l'Abbé Lenglet du Fresnoy A Paris: chez De Bure l'aîné..., 1739 . 